\author{
UNIVERSIDADE DE SÃO PAULO \\ ESCOLA DE ARTES CIÊNCIAS E HUMANIDADES \\ PROGRAMA DE PÓS-GRADUAÇÃO EM GERONTOLOGIA
}

JULLYANNE MARQUES SOUSA TEIXEIRA

O GERONTÓLOGO COMO GESTOR DO CUIDADO FORMAL DOMICILIAR:

UM OLHAR DA FENOMENOLOGIA SOCIAL

São Paulo

2018 


\section{O GERONTÓLOGO COMO GESTOR DO CUIDADO FORMAL DOMICILIAR: UM OLHAR DA FENOMENOLOGIA SOCIAL}

Dissertação apresentada à Escola de Artes, Ciências e Humanidades da Universidade de São Paulo para obtenção do título de Mestre em Ciências pelo Programa de Pós-graduação em Gerontologia.

Versão corrigida contendo as alterações solicitadas pela comissão julgadora em 16 de março de 2018. A versão original encontra-se em acervo reservado na Biblioteca da EACH/USP e na Biblioteca Digital de Teses e Dissertações da USP (BDTD), de acordo com a Resolução CoPGr 6018, de 13 de outubro de 2011.

Área de concentração:

Saúde, Envelhecimento e Doenças crônicas

Orientadora:

Profa. Dra. Rosa Yuka Sato Chubaci

São Paulo 
Autorizo a reprodução e divulgação total ou parcial deste trabalho, por qualquer meio convencional ou eletrônico, para fins de estudo e pesquisa, desde que citada a fonte.

CATALOGAÇÃO-NA-PUBLICAÇÃO

(Universidade de São Paulo. Escola de Artes, Ciências e Humanidades. Biblioteca) CRB-8 4936

Teixeira, Jullyanne Marques Sousa

O gerontólogo como gestor do cuidado formal domiciliar: um olhar da fenomenologia social / Jullyanne Marques Sousa Teixeira ; orientadora, Rosa Yuka Sato Chubaci. - 2018 $135 \mathrm{f}$.

Dissertação (Mestrado em Ciências) - Programa de PósGraduação em Gerontologia, Escola de Artes, Ciências e Humanidades, Universidade de São Paulo, São Paulo Versão corrigida

1. Assistência a idosos - Brasil. 2. Idosos - Aspectos sociais - Brasil. 3. Gerontologia - Brasil. 4. Cuidadores de idosos. I. Chubaci, Rosa Yuka Sato, orient. II. Título.

CDD 22.ed. - 362.60981 
TEIXEIRA, Jullyanne Marques Sousa

O gerontólogo como gestor do cuidado formal domiciliar: um olhar da fenomenologia social

Dissertação apresentada à Escola de Artes, Ciências e Humanidades da Universidade de São Paulo para obtenção do título de Mestre em Ciências pelo Programa de Pós-graduação em Gerontologia.

Área de concentração:

Saúde, Envelhecimento e Doenças crônicas

Aprovado em: 16/03/2018

\section{Banca Examinadora}

$\begin{array}{llll}\text { Prof. Dr. } & \text { Helena A. W. Watanabe } & \text { Instituição: } & \text { FSP-USP } \\ \text { Julgamento: } & \text { Aprovada } & \text { Assinatura: } & \\ & & & \\ \text { Prof. Dr. } & \text { Beatriz A. O. Gutierrez } & \text { Instituição: } & \text { EACH-USP } \\ \text { Julgamento: } & \text { Aprovada } & \text { Assinatura: } & \\ & & & \\ \text { Prof. Dr. } & \text { Sofia C. Iost Pavarini } & \text { Instituição: } & \text { UFSCar - Externo } \\ \text { Julgamento: } & \text { Aprovada } & \text { Assinatura: } & \end{array}$




\section{Dedicatória}

Dedico este trabalho às pessoas mais presentes em minha vida:

Minha mãe, pelo exemplo de vida que é.

Meu pai, por sempre acreditar no meu potencial acadêmico e profissional. Minha vó Eraides, por me criar, me amar e me inspirar cada dia mais e mais. Meus irmãos, Jullya e Paulo, pelo incentivo direto ou indireto. Meus amigos, pelas risadas e paciência do dia a dia. Meus familiares, que me motivam ao longo da minha vida a querer ser sempre melhor. 


\section{Agradecimentos}

Primeiramente, aos meus pais, Glória e Paulo, por terem me dado educação, valores e por sempre acreditarem em minha capacidade. Isso só me fortalece e me faz a cada dia querer ser melhor. Obrigada pelo amor incondicional, pela companhia e pelas palavras de incentivo.

A todos os meus familiares, madrinha, padrinho, primos e primas, tios e tias. Em especial aos meus irmãos, Jullya e Paulo, que mesmo longe sempre foram minha fonte de inspiração e alegria.

Aos meus amigos, Priscilla, Gabriel, Mariana, Patrícia, Karen, Carter, Talita, Léo e Karen... por todo o incentivo e paciência. Agradeço por sempre escutarem minhas reclamações e angústias. Vocês são especiais. Sem vocês esse caminho seria muito mais longo e difícil.

À minha orientadora querida, Profa. Dra. Rosa Yuka Sato Chubaci, mais conhecida como Rosinha, meus sinceros agradecimentos. Sem você nada seria possível. Agradeço pela confiança em meu trabalho, pela parceria ao longo de todos esses anos, pela disponibilidade, atenção dispensada, paciência e dedicação.

Ao meu namorado, Matheus, que chegou no final e me ajudou a concluir este ciclo com mais calma, sabedoria e confiança. Obrigada por me fazer aprender com a sua experiência mozão. Te amo!

Aos meus amigos e parceiros Sandra e Alessandro, por compreenderem minhas dificuldades durante o período do mestrado. Obrigada pelo incentivo, paciência e carinho.

Aos professores, funcionários e colegas da Pós-Graduação em Gerontologia da EACH-USP, pelo apoio ao longo desses dois anos e pela solidariedade perante minhas dificuldades.

Agradeço a todas as gerontólogas e cuidadoras que prontamente participaram da pesquisa e me motivaram, com seus depoimentos, a continuar firme na missão de me tornar mestre.

Com vocês, queridos, divido a alegria desta experiência. 
"Aprendi que a vida, apesar de bruta, é meio mágica. Dá sempre pra tirar um coelho da cartola. E lá vou eu, nas minhas tentativas, às vezes meio cegas, às vezes meio burras, tentar acertar os passos. Sem me preocupar se a próxima etapa será o tombo ou o voo. Eu sei que vou. Insisto na caminhada. O que não dá é pra ficar parado. Se amanhã o que eu sonhei não for bem aquilo, eu tiro um arco-íris da cartola. E refaço. Colo. Pinto e bordo. Porque a força de dentro é maior. Maior que todo mal que existe no mundo. Maior que todos os ventos contrários. É maior porque é do bem. E nisso, sim, acredito até o fim..." 


\section{RESUMO}

TEIXEIRA, Jullyanne Marques Sousa. O gerontólogo como gestor do cuidado formal domiciliar: um olhar da fenomenologia social. 2018. 135f. Dissertação (Mestrado em Ciências) Escola de Artes Ciências e Humanidades, Universidade de São Paulo, São Paulo, 2018. Versão corrigida.

À medida que o ser humano envelhece as doenças crônicas tornam-se mais frequentes, o que faz com que os idosos necessitem de mais atenção à saúde. Paralelo a este cenário, a estrutura familiar brasileira vem passando por modificações e, atualmente, fica cada vez mais difícil que o cuidado fornecido ao idoso venha de membros da família. Muitas empresas privadas já contam com a oferta de cuidadores de idosos para atendimento domiciliar, outras poucas estão utilizando um novo formato de assistência à saúde do idoso, com a inclusão de gerontólogos na gestão do cuidado. Objetivo: compreender o significado do gerontólogo bacharel como gestor do cuidado formal domiciliar, através da perspectiva dos gerontólogos e cuidadores formais envolvidos diretamente no cuidado ao idoso. Método: A pesquisa foi qualitativa e teve como referencial metodológico a fenomenologia social. Foram entrevistados 20 participantes, que trabalhavam em empresas de atendimento domiciliar localizadas na cidade de São Paulo, sendo 15 cuidadores formais e cinco gerontólogos. Os depoimentos foram coletados por meio de perguntas norteadoras, gravados e transcritos. Para análise dos dados foi realizada a categorização dos significados a partir da redução fenomenológica. Resultados: a partir dos depoimentos foi possível verificar que os gerontólogos zelam pelo cuidado à saúde do idoso; capacitam e orientam os cuidadores de idosos; dão suporte integral e eficaz aos cuidadores; administram as informações; dão orientação e suporte aos familiares; unem a equipe interprofissional, familiares e cuidadores; gerenciam os conflitos familiares; auxiliam o cuidador no processo de adaptação com o paciente; entre outras categorias. Conclusão: A compreensão dos significados do gerontólogo como gestor do cuidado formal domiciliar mostra que este profissional, com sua formação generalista e interdisciplinar sobre o envelhecimento e a velhice, consegue desenvolver uma visão integral do idoso, compreender e atender suas necessidades biopsicossociais, trabalhar em equipe e atuar ativamente na assistência. Todos os cuidadores entrevistados apresentam uma visão definida e positiva em relação à atuação do gerontólogo. Enfatizaram que a falta de uma gestão gerontológica afeta diretamente na qualidade do cuidado prestado ao idoso.

Palavras-chave: Gerontologia. Assistência domiciliar. Cuidadores 


\begin{abstract}
TEIXEIRA, Jullyanne Marques Sousa.The gerontologist as manager of formal home care: a look at social phenomenology.2018. 135p. Dissertation (Master of Science) - School of Arts, Sciences and Humanities, University of São Paulo, São Paulo, 2018. Revised version.
\end{abstract}

As the human being ages, chronic diseases become more frequent, which makes the elderly need more attention to health. In parallel to this scenario, the Brazilian family structure has been undergoing changes and, at present, it is increasingly difficult for the family members to provide the care needed by the elderly. Many private companies already have the supply of caregivers of elderly people for home care, others are using a new form of health care for the elderly, with the inclusion of gerontologists in the management of care. Objective: to understand the meaning of the bachelor gerontologist as manager of the formal home care, from the perspective of gerontologists and formal caregivers directly involved in care for the elderly. Method: The research is qualitative and had as methodological reference the social phenomenology. Twenty participants were interviewed, who work in home care companies located in the city of São Paulo, 15 formal caregivers and five gerontologists. The testimonies were collected through guiding questions, recorded and transcribed. For the analysis of the data the categorization of the meanings was carried out from the phenomenological reduction. Results: from the testimony it was possible to verify that the gerontologists: care for the health care of the elderly; train and mentor caregivers of the elderly; provide comprehensive and effective support to caregivers; manage the information; give guidance and support to family members; unite interprofessional staff, family members and caregivers; manage family conflicts; assist the caregiver in the process of adaptation with the patient; among other categories. Conclusion: The understanding of the gerontologist's meanings as a manager of formal home care shows that this professional, with his general and interdisciplinary training on aging and old age, is able to develop an integral view of the elderly, understand and respond to their biopsychosocial needs, work as a team and act actively in the care. All caregivers interviewed present a definite and positive view regarding the performance of the gerontologist. They emphasized that the lack of gerontological management directly affects the quality of care provided to the elderly.

Keywords: Gerontology. Home Care. Caregivers. 


\section{LISTA DE FIGURAS}

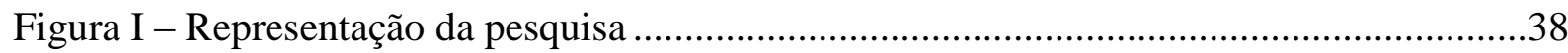

Figura II - Representação do Esquema Metodológico (Gerontólogos).....................................39

Figura III - Representação do Esquema Metodológico (Cuidadores de idosos) ........................40

Figura IV - Esquema representativo da análise compreensiva................................................41

Figura V - Dificuldades enfrentadas pelos gerontólogos no ambiente de trabalho....................85 


\section{LISTA DE QUADROS}

Quadro 1 - Motivos porque os cuidadores trabalham com o gerontólogo ............................44

Quadro 2 - Motivos para os cuidadores trabalharem com o gerontólogos............................48

Quadro 3 - Motivos porque os gerontólogos trabalham no cuidado domiciliar......................59

Quadro 4 - Motivos para os gerontólogos trabalharem no cuidado domiciliar........................64

Quadro 5 - Categorias Motivos Para e Motivos Porque dos Cuidadores e Gerontólogos........82 


\section{LISTA DE ABREVIATURAS E SIGLAS}

$\begin{array}{ll}\text { AD } & \text { Assistência Domiciliar } \\ \text { TCC } & \text { Trabalho de Conclusão de Curso } \\ \text { PNAD } & \text { Pesquisa Nacional por Amostra de Domicílios } \\ \text { PNS } & \text { Pesquisa Nacional de Saúde } \\ \text { ILPI’s } & \text { Instituições de Longa Permanência para Idosos } \\ \text { AVDs } & \text { Atividades de Vida Diária } \\ \text { USP } & \text { Universidade de São Paulo } \\ \text { Ufscar } & \text { Universidade Federal de São Carlos } \\ \text { FAI } & \text { Faculdades Adamantineses Integradas } \\ \text { TCLE } & \text { Termo de Consentimento Livre e Esclarecido } \\ \text { CEUCLAR } & \text { Centro Universitário Claretiano } \\ \text { CBO } & \text { Classificação Brasileira de Ocupações }\end{array}$




\section{SUMÁRIO}

INTRODUÇÃO...................................................................................... 17

1.1 O DESPERTAR PELA TEMÁTICA.......................................................... 17

$1.2 \quad$ A LITERATURA SOBRE A TEMÁTICA................................................... 18

1.2.1 Envelhecimento populacional brasileiro......................................................... 18

1.2.2 Impacto do envelhecimento na família............................................................... 19

1.2.3 Demanda pela assistência domiciliar: cuidadores........................................ 22

1.2.4 Necessidade da equipe interprofissional......................................................... 25

1.2.5 A atuação do gerontólogo na equipe multiprofissional................................. 26

2 JUSTIFICATIVA......................................................................................... 30

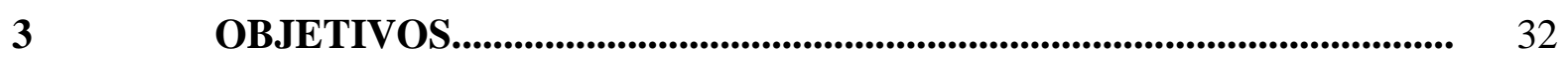

$3.1 \quad$ OBJETIVO GERAL ……………………....................................... 32

3.2 OBJETIVOS ESPECÍFICOS ……………...................................... 32

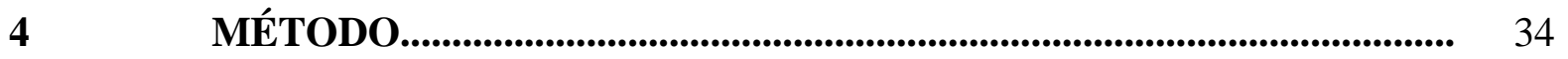

$4.1 \quad$ REFERENCIAL METODOLÓGICO_........................................................ 34

4.2 LOCAL DE ESTUDO........................................................................ 35

$4.3 \quad$ PARTICIPANTES DA PESQUISA.......................................................... 35

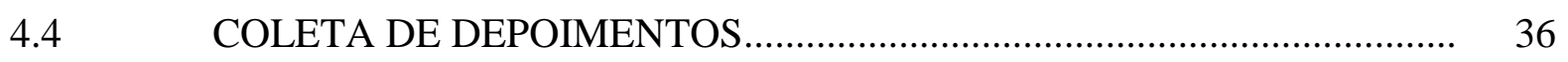

4.5 ANÁLISE DOS DADOS ...................................................................... 36

4.6 QUESTÕES ÉTICAS....................................................................... 37

$5 \quad$ RESULTADOS E DISCUSSÃO ............................................................ 43

5.1 CARACTERIZAÇÃO DOS PARTICIPANTES........................................... 43

5.2 ANÁLISE COMPREENSIVA................................................................ 43

5.2.1 Apresentação das categorias de Motivos Porque e Motivos Para............ 43

5.2.1.1 Motivos porque os cuidadores trabalham com o gerontólogo....................... 43

5.2.1.1.1 Por indicacão ........................................................................................................... 44

5.2.1.1.2 Poder administrar melhor o cotidiano............................................................... 44

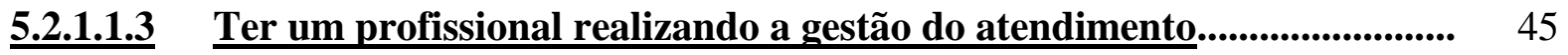

5.2.1.1.4 Evitar a inseguranca e solidão de ser cuidador.............................................. 45

5.2.1.1.5 Ter supervisão das atribuicões do cuidador..................................................... 46 
5.2.1.1.6 Não precisar tratar diretamente com a família............................................... 47

5.2.1.2 Motivos para os cuidadores trabalharem com o gerontólogo ....................... 48

5.2.1.2.1 Administrar as informações sobre os idosos.................................................... 48

5.2.1.2.2 Identificar e atender as necessidades do paciente......................................... 49

5.2.1.2.3 Orientar o paciente e seus familiares ................................................................ 49

5.2.1.2.4 Unir equipe multiprofissional, familiares e cuidadores .............................. 50

5.2.1.2.5 Realizar trabalhos administrativos.................................................................... 51

5.2.1.2.6 Acompanhar presencialmente o atendimento realizado …......................... 52

5.2.2.1.7 Acolher a equipe de cuidadores, familiares e paciente ............................... 52

5.2.1.2.8 Dar seguranca para os cuidadores ........................................................................ 53

5.2.1.2.9 Auxiliar o cuidador no processo de adaptacão com o paciente................. 53

5.2.1.2.10 Dar suporte integral e eficaz para os cuidadores ……................................... 54

5.2.1.2.11 Orientar a equipe de cuidadores …................................................................ 55

5.2.1.2.12 Apoiar no processo de luto ................................................................................... 55

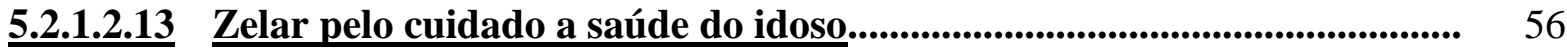

5.2.1.2.14 Adaptar o ambiente para a seguranca do idoso............................................. 57

5.2.1.2.15 Não precisar tratar diretamente com a família.............................................. 57

5.2.1.2.16 Gerenciar os conflitos familiares....................................................................... 58

5.2.1.3 Motivos porque os gerontólogos trabalham no cuidado domiciliar............ 59

5.2.1.3.1 Acreditar no modelo de atendimento domiciliar............................................... 59

5.2.1.3.2 Ter a demanda de clientes e cuidadores.............................................................. 60

5.2.1.3.3 Acreditar no trabalho do gerontólogo................................................................. 60

5.2.1.3.4 Trabalhar diretamente com o idoso no domicílio.......................................... 61

$\underline{\text { 5.2.1.3.5 }}$ Facilidade de conseguir o emprego.................................................................... 61

5.2.1.3.6 Experiência Acadêmica.......................................................................................... 62

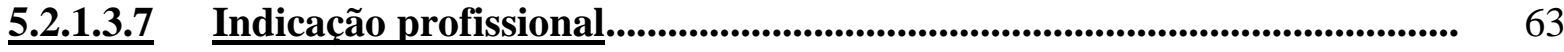

5.2.1.4 Motivos para os gerontólogos trabalharem no cuidado domiciliar............. 64

5.2.1.4.1 Realizar a gestão gerontológica do atendimento …………............................. 65

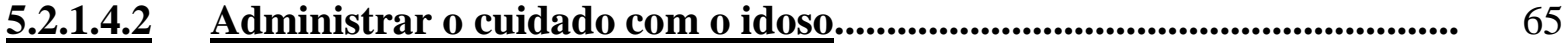

5.2.1.4.3 Acompanhar presencialmente o atendimento realizado............................... 66

5.2.1.4.4 Administrar as informacões sobre o idoso....................................................... 67 


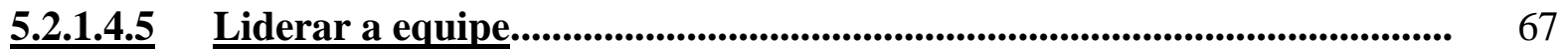

5.2.1.4.6 Unir equipe multiprofissional, familiares e cuidadores................................ 68

5.2.1.4.7 Gerenciar a escala da equipe de cuidadores.................................................... 68

5.2.1.4.8 Identificar e atender as necessidades do paciente e sua família............... 69

5.2.1.4.9 Mediar e gerenciar o cuidado............................................................................. 69

5.2.1.4.10 Supervisionar o cuidado.............................................................................. 71

5.2.1.4.11 Capacitar e orientar os cuidadores de idosos................................................... 71

5.2.1.4.12 Dar suporte integral e eficaz para os cuidadores........................................... 72

$\underline{\text { 5.2.1.4.13 }}$ Adaptar 0 ambiente para a seguranca do idoso............................................. 73

5.2.1.4.14 Avaliar 0 idoso.............................................................................................................. 73

5.2.1.4.15 Ajudar a melhorar a saúde do idoso................................................................... 74

5.2.1.4.16 Ter contato próximo com o idoso......................................................................... 74

5.2.1.4.17 Incentivar a autonomia e a independência do idoso...................................... 75

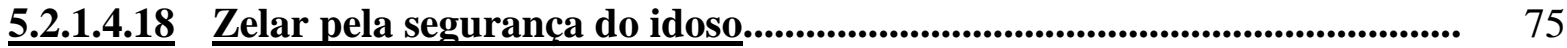

5.2.1.4.19 Dar orientaç̃o e suporte para os familiares.................................................... 77

5.2.1.4.20 Incentivar a família para um melhor cuidado................................................ 77

5.2.1.4.21 Divulgar a profissão de gerontólogo............................................................ 78

5.2.1.4.22 Ser valorizado como gerontólogo....................................................................... 79

5.2.1.4.23 Aprender com as situacões e ter resolutividade.............................................. 79

5.2.1.4.24 Ter mais flexibilidade e autonomia no trabalho............................................. 80

5.2.1.4.25 Colocar os conhecimentos teóricos em prática................................................ 80

5.2.2 Construção do tipo vivido..................................................................................... 82

5.2.2.1 Tipo vivido dos Cuidadores............................................................................... 84

5.2.2.2 Tipo vivido dos Gerontólogos......................................................................... 84

5.2.3 Apresentação das dificuldades enfrentadas por cuidadores e $\quad 85$

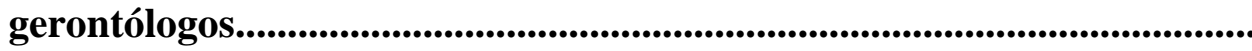

5.2.3.1 Dificuldades em relação à profissão.................................................................... 85

5.2.3.2 Dificuldades de lidar com o atendimento de forma geral................................ 86

5.2.3.3 Dificuldade de relacionamentos........................................................................ 86

5.2.3.4 Dificuldade com questões relativas a recursos humanos................................ 86

$6 \quad$ CONSIDERAÇÕES FINAIS............................................................................ 88 


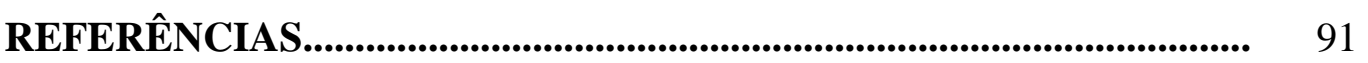

Apêndice A - QUESTIONÁRIO CUIDADORES...................................... 94

Apêndice B - QUESTIONÁRIO GERONTÓLOGOS............................... 96

Apêndice C - TERMO DE CONSENTIMENTO LIVRE E

ESCLARECIDO (CUIDADORES)...................................................................

Apêndice D - TERMO DE CONSENTIMENTO LIVRE E 100

ESCLARECIDO (GERONTÓLOGOS)....................................................

Anexo A - APROVAÇÃO DO COMITÊ DE ÉTICA EM PESQUISA.. 102

Anexo B - CATEGORIAS CUIDADORES (íntegra).................................. 105

Anexo C - CATEGORIAS GERONTÓLOGOS (íntegra)......................... 120 


\section{INTRODUÇÃO}

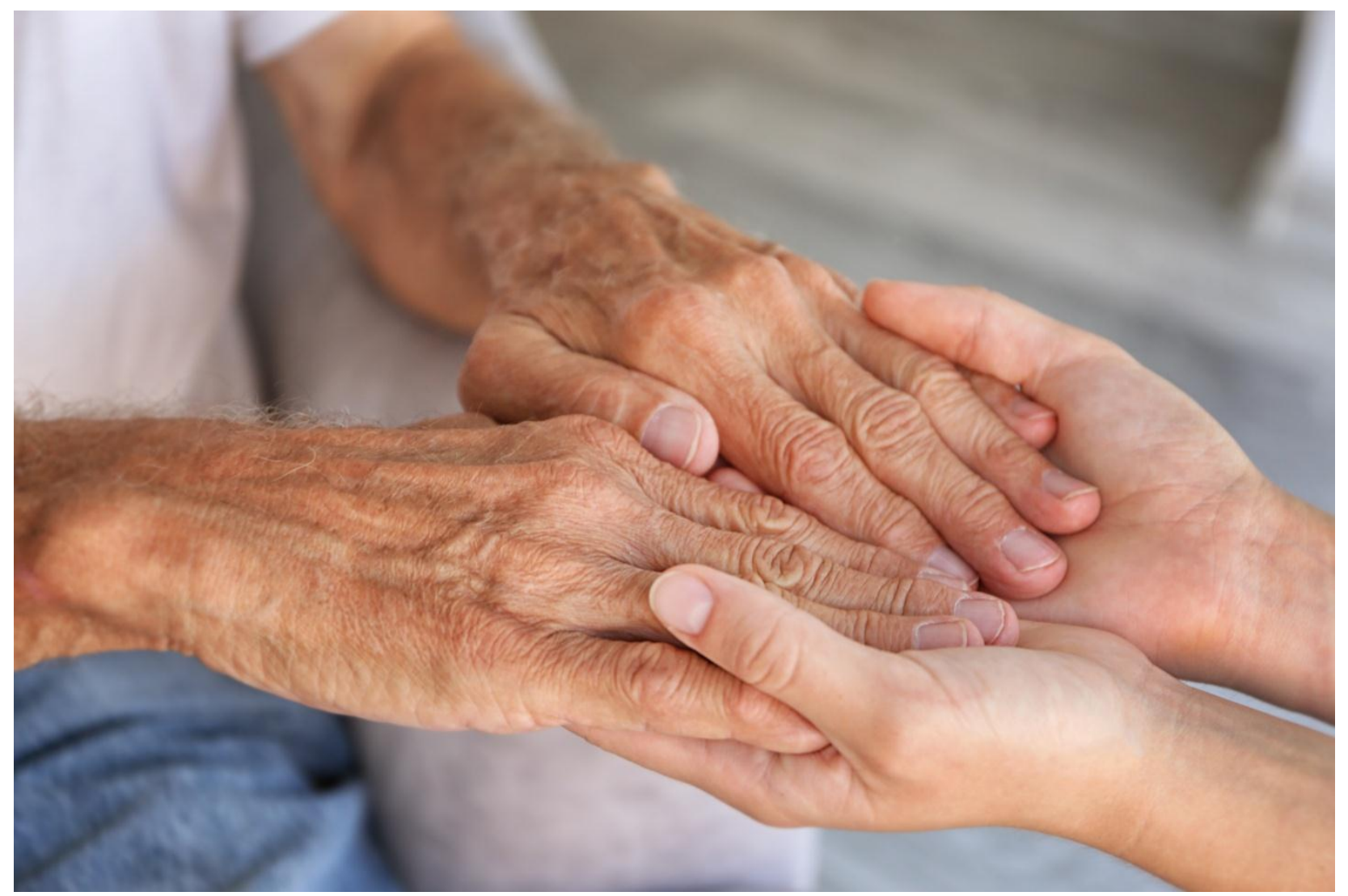

Fonte: Banco de Imagens Shutterstock, 2017 


\section{INTRODUÇÃ̃O}

\subsection{O DESPERTAR PELA TEMÁTICA}

Envelhecer é um processo inerente a todos os seres humanos. A velhice é uma das etapas do curso da vida, parte integrante de um ciclo natural, constituindo-se como uma experiência singular e diferenciada.

Considerando-se as questões de envelhecimento populacional e, consequentemente, a ampliação das demandas relacionadas à velhice, a preocupação com a qualidade de vida para essa faixa etária está cada vez mais presente.

Este trabalho foi motivado pela experiência pessoal e profissional da pesquisadora, que desde 2003 interessa-se pela população idosa através de trabalhos voluntários. E que em 2006, ao ingressar no curso de Graduação em Gerontologia pela Universidade de São Paulo (USP), aumentou ainda mais seu interesse pela velhice e pelo processo de envelhecer.

Durante sua trajetória acadêmica realizou estágios curriculares em diversos equipamentos e programas de atenção ao idoso, entre os quais o Programa de Atenção Domiciliar do Hospital Universitário da USP que lhe proporcionou uma profunda reflexão sobre o ato de cuidar em casa, haja vista, que muitas famílias atendidas pelo programa supracitado não tinham recursos financeiros para terceirizarem o cuidado ao idoso e, por esse motivo, acabavam assumindo esta responsabilidade, que gera sobrecarga física e emocional para muitos familiares.

Motivada a explorar as formas que o cuidado ao idoso era realizado no domicílio, realizou seu Trabalho de Conclusão de Curso (TCC) na área da Assistência Domiciliar (AD), com o objetivo de identificar o significado da AD para o idoso e sua família. A pesquisa foi realizada em uma empresa privada de Home Care localizada na cidade de São Paulo.

Em 2011, concluiu a Graduação em Gerontologia e iniciou sua trajetória profissional na empresa onde havia realizado sua pesquisa de TCC e, a partir disso, teve a oportunidade de atuar na gestão e treinamento de cuidadores profissionais de idosos. A pesquisadora foi a primeira gerontóloga graduada a atuar em Home Care, fato esse, que se converteu em uma experiência desafiadora e satisfatória.

Em busca de crescimento profissional, em 2015, a pesquisadora abriu sua própria empresa de cuidadores e continuou atuando com a gestão e treinamento dos cuidadores de idosos formais. Com interesse em compreender a maneira que os demais gerontólogos estão atuando no cenário domiciliar, a pesquisadora iniciou seu projeto de mestrado, acreditando que sua pesquisa poderá 
contribuir para um entendimento mais assertivo sobre as atribuições e o papel do gerontólogo como gestor do cuidado formal domiciliar.

\subsection{A LITERATURA SOBRE A TEMÁTICA}

\subsubsection{Envelhecimento populacional brasileiro}

Assim como a infância, a adolescência e a maturidade, o envelhecimento também é um processo da vida marcado por alterações biopsicossociais específicas, influenciadas pelo impacto da passagem do tempo na vida do indivíduo. Décadas atrás, envelhecer era privilégio de uma pequena parcela da população. Contudo, atualmente observamos um número crescente de pessoas em todo o mundo vivenciando essa experiência (Oliveira, 2010).

No Brasil, o envelhecimento populacional assume características representativas e peculiares, dadas a velocidade e a intensidade com que vem instalando-se. Essa mudança demográfica faz com que o envelhecimento ganhe destaque no cenário nacional (Silva et al., 2007). De acordo com os dados da Pesquisa Nacional por Amostra de Domicílios - PNAD, a proporção de idosos de 60 anos ou mais de idade passou de 9,7\%, em 2004, para 13,7\%, em 2014, sendo o grupo etário que mais cresceu em toda população (IBGE, 2015). Estima-se que hoje o Brasil tenha 26 milhões de pessoas acima dos 60 anos. (IBGE, 2017). As projeções apontam que teremos, em 2025, cerca de 32 milhões de idosos no Brasil, o que nos colocará na sexta posição entre os países com maior proporção de idosos no mundo (Camarano, 2004).

Atualmente, muito vem se discutindo sobre o aumento da expectativa de vida, a diminuição da natalidade e o acelerado processo do envelhecimento da população. Sem dúvida, um dos maiores progressos da humanidade foi a ampliação do tempo de vida, entretanto, este feito transforma-se em um grande desafio para toda a sociedade, afinal, o processo de envelhecimento demográfico repercute na estrutura social, econômica, política e cultural da sociedade, uma vez que os idosos, da mesma forma que outras faixas etárias (crianças, jovens e adultos), possuem necessidades e carências específicas para conquistar condições de vida adequadas.

Viver por mais tempo é significativo para a humanidade, desde que haja qualidade aos anos adicionais de vida, dessa forma, é urgente que novos meios sejam encontrados para integrar aos idosos à nossa sociedade, que conceitos já enraizados no discurso social sejam modificados e que novas tecnologias sejam utilizadas, com inovação e sabedoria, a fim de alcançarmos, de forma justa 
e democrática, a equidade na distribuição dos serviços e facilidades para o grupo populacional que mais cresce no país.

Dados da Pesquisa Nacional de Saúde - PNS (2013) - referente às limitações funcionais das pessoas de 60 anos ou mais de idade para realizar sozinhas suas atividades da vida diária, como, por exemplo, comer, tomar banho, ir ao banheiro, vestir-se, andar em casa de um cômodo a outro, seja no mesmo andar ou não, e deitar-se, revelaram que no Brasil, 6,8\% das pessoas dessa faixa etária apresentavam limitação funcional para realização de suas atividades cotidianas. Verificouse ainda que quanto mais elevada a idade, a proporção de pessoas com tais limitações também crescia, variando de 2,8\%, para aquelas de 60 a 64 anos, a 15,6\%, para as de 75 anos ou mais de idade (IBGE, 2015).

Outro dado importante dessa pesquisa é que, entre os idosos de 60 anos ou mais de idade que tinham alguma limitação funcional, 84,0\% declararam precisar de ajuda para a realização das atividades de vida diária. A PNS 2013 investigou o tipo de cuidado recebido por esses idosos, a saber: $78,8 \%$ recebiam cuidados de familiares; $17,8 \%$ recebiam cuidados remunerados; e $10,9 \%$ não recebiam ajuda para realizar as atividades da vida diária. Estes resultados apontam para questões referentes à escassa oferta de serviços e equipamentos para atender a este público que apresenta limitações funcionais, e também para a questão de gênero, ou seja, aos papéis esperados a determinado gênero, uma vez que a mulher tende a ser a principal responsável pelas atividades de cuidado dentro da família. Como existe uma tendência ao envelhecimento populacional, o cuidado dos idosos é uma questão que se coloca em debate e na agenda das políticas públicas (IBGE, 2015).

\subsubsection{Impacto do envelhecimento na família}

Em conformidade com o Ministério da Saúde (2006), o cuidado à pessoa idosa compreende diversos atores: idoso, família, cuidador (se existente), comunidade e as equipes de atenção à saúde, que atuam de forma interrelacionada no desempenho das atividades de atenção às demandas do idoso, as quais são identificadas por meio das relações interpessoais.

No sistema familiar que há presença de um idoso doente, frequentemente, um membro da família é escolhido para desempenhar o papel de cuidador, estabelecendo a relação de cuidador informal (Falcão, 2006). Assim sendo, a experiência de cuidar de um idoso dentro de casa tem se tornado cada vez mais frequente nas famílias. Cabe, neste contexto, ressaltar a responsabilidade 
que o próprio Estatuto do Idoso atribui à família em relação ao cuidado do idoso dependente, sem considerar as mudanças na estrutura familiar e no papel social de seus membros. No Estatuto do Idoso (lei 10.741/03), o art. $3^{\circ}$ diz que "é obrigação da família, da comunidade, da sociedade e do Poder Público, assegurar ao idoso, com absoluta prioridade, a efetivação do direito à vida, à saúde, à alimentação, à educação, à cultura, ao esporte, ao lazer, ao trabalho, à cidadania, à liberdade, à dignidade, ao respeito e à convivência familiar e comunitária", havendo "a priorização do atendimento do idoso por sua própria família, em detrimento do atendimento asilar, exceto dos que não a possuam ou careçam de condições de manutenção da própria sobrevivência" (art. 30, parágrafo V).

Atualmente, a concepção de família e sua estrutura estão em grandes e constantes transformações, devido às readaptações e mudanças de nossa sociedade. Até pouco tempo atrás, o cuidado era comumente reservado à mulher, sendo essa considerada como a tradicional provedora de cuidados básicos aos idosos dentro do núcleo familiar (Falcão; Bucher-Maluschke, 2010). No entanto, a estrutura familiar na realidade brasileira está sendo alterada. As famílias estão cada vez menores e a mulher não mais trabalha, exclusivamente, no lar, ao contrário, engaja-se cada vez mais no mercado de trabalho (Kawasaki; Diogo, 2001). Atrelada a essa questão, ocorre também o declínio da fecundidade, o que gera a diminuição do número de filhos por mulher e com isso, a redução à oferta de cuidadores familiares. As mudanças na nupcialidade e nos arranjos familiares também podem relacionar-se com a baixa oferta de cuidado familiar, já que o esperado é que haja menor atenção dos familiares quando ocorrem mais casamentos (Camarano, 2010).

Segundo os dados do Censo 2010 (IBGE, 2011), os arranjos familiares são menos tradicionais; tem crescido o número de uniões consensuais, representando mais de um terço dos casamentos; além do aumento da quantidade de divórcios, fatos esses que acarretam dois eventos, são eles: o crescimento das famílias reconstituídas, nas quais o filho pode ser apenas de um dos cônjuges e o aumento da porcentagem de crianças que vivem em famílias monoparentais. Ademais, observa-se também no Censo 2010, um crescimento no percentual de casais sem filhos entre os anos de 2000 e 2010.

Em paralelo, os brasileiros têm valorizado a vida independente, ou seja, o número de pessoas que vivem sozinhas também está em constante ampliação. No Brasil, entre 1998 e 2008, a proporção de pessoas que moravam sozinhas aumentou de 8,4\% para 11,6\% (IBGE, 2011). 
Tais modificações no perfil da família brasileira podem enfraquecer as relações de solidariedade intergeracionais e influenciar a economia do cuidado (Ribeiro, 2015). A família brasileira ainda tem sido a cuidadora principal de seus membros, entretanto, a capacidade de exercer essa função vem enfraquecendo-se (Camarano, 2010). Além disso, o cuidado diário e permanente ao idoso dependente produz perturbações que, por menor que sejam, afetam a vida familiar.

A mudança no exercício de papéis, angustiante em virtude do envolvimento afetivo entre paciente idoso e família, a diminuição do tempo de relacionamento com amigos e vizinhança, a solidão, a sobrecarga e a frustração por não conseguir colocar em prática seus próprios projetos de vida, fazem parte das perturbações que, em determinado momento, saturam o cuidador familiar, de forma que esse passe a procurar alternativas que lhe ajudem a lidar com as problemáticas deste processo como, por exemplo, contratando um indivíduo para prestar a assistência necessária ao idoso. Indivíduos estes denominados de cuidadores formais, os quais não raramente, assumem sozinhos à assistência ao idoso, sem o auxílio de uma equipe para dividir as responsabilidades e demandas exigidas pela tarefa (Neri, 1993 apud Kawasaki; Diogo, 2001).

Muitos cuidadores familiares não têm as necessidades atendidas e gostariam de mais informações, preparação e apoio para auxiliá-los nas tarefas e responsabilidades relacionadas ao cuidado. Há uma escassez de estratégias para orientar estes cuidadores informais e falta de profissionais adequados para fornecer suporte ideal enquanto o cuidador está prestando cuidados e após a morte do paciente (Hudson et al., 2012).

Um estudo realizado na Colombia, (Arias-Rojas et al., 2014) traz que o cuidado de pessoas portadoras de doenças crônicas está associado ao comprometimento da saúde do cuidador familiar, principalmente quando este não possui suporte suficiente para oferecer o cuidado. Os autores sugerem, com base nos resultados, o estabelecimento de políticas e programas, que além de atender as pessoas portadoras de doença crônica, incluam seus cuidadores familiares. A pesquisa traz ainda que programas destinados a apoiar o cuidador demonstraram ser significativos para aumentar a percepção da capacidade de cuidar ou diminuir a percepção de sobrecarga de cuidado.

Segundo levantamento de uma revisão sistemática realizada por pesquisadores na Bélgica, (Schoenmakers et al., 2010) os cuidadores de idosos portadores de demência sofrem com sentimentos de depressão e diminuição da saúde física. A depressão atinge um em cada três 
cuidadores sendo mais frequente naqueles que cuidam de pacientes com demência que em cuidadores responsáveis por pacientes com doenças crônicas.

Um estudo realizado na Suiça, (Kesselring et al., 2001) com cuidadores familiares, em sua maioria, mulheres (73\%), e esposas (67\%), aponta que após um tempo médio de cuidado, 5,5 anos, os cuidadores relataram predominantemente efeitos negativos do cuidado na sua saúde física e mental, descanso e sono, tempo de lazer e vida social.

Em suma, cresce o número de idosos, por conseguinte cresce também a demanda de cuidados para esta população. Todavia, a capacidade da família de cuidar de seus idosos está cada vez menor, identificando-se assim uma emergencial necessidade de incremento de serviços para atendê-los adequadamente sem a obrigação de tirá-los de seu ambiente familiar. Neste cenário, com a preocupação em proporcionar ao idoso um atendimento cada vez mais humanizado, qualificado, profissional, o qual garanta assistência contínua e integral, surge o cuidado domiciliar formal.

A literatura gerontológica consagrou o uso dos termos formal e informal, para caracterizar, o grupo de apoio que atua com base em relações profissionais e o grupo que funciona a partir das relações de parentesco, amizade e coletivismo, respectivamente. No Brasil, a rede de apoio formal aos idosos é representada por hospitais, ambulatórios, consultórios médicos e outras especialidades na área da saúde, também por clínicas geriátricas, casas de repouso, Instituições de Longa Permanência para Idosos (ILPI’s), centros-dia e, mais recentemente, unidades de apoio domiciliar, as quais serão tratadas ao longo deste estudo (Neri; Sommerhalder, 2006).

\subsubsection{Demanda pela assistência domiciliar: cuidadores}

O termo cuidar origina-se do Latim cogitare e é definido como "aplicar à atenção a", "tratar", "interessar-se por" (Ferreira, 2004). O cuidar faz parte das necessidades básicas para a sobrevivência da vida humana: o cuidar de si, o cuidar do outro e o ser cuidado. O cuidar significa um direito de cidadania à nossa capacidade de sentir o outro, de ter compaixão por pessoas que sofrem, de ter cordialidade e gentileza (Vidal et al., 2012).

O Cuidar é considerado um conceito amplo e multidisciplinar que contém diversas vertentes: técnica, relacional, afetiva, ética, sociocultural e terapêutica. Remete à tarefa que visa manter a vida satisfazendo um conjunto de necessidades indispensáveis. É o ato de apoiar alguém 
ou prestar-lhe um serviço, com um risco substancial de doenças, sejam estas físicas ou mentais, além de ser um processo interativo entre o cuidador e a pessoa cuidada (Ricarte, 2009).

Duas teorias sobre o cuidar frequentemente embasam estudos nesta área (Crivaro; Almeida \& Souza, 2007): a Teoria da Prática Humanística de Paterson e Zderad (1976) e a Teoria do Cuidar Transpessoal de Jean Watson (1979/1985). A primeira, Teoria da Prática Humanística, defende o diálogo vivo entre o enfermeiro e o paciente de forma a corroborar com o bem-estar daquele que cuida e daquele que é cuidado, tendo com ideia central o diálogo. De acordo com essa teoria, o diálogo entre os cuidadores e o ser cuidado ocorre através do encontro, do relacionamento, da presença, com valorização da interação humana, tão importante para o ser que cuida e para quem é cuidado. Já a Teoria do Cuidar Transpessoal, de Jean Watson, refere-se a uma relação intersubjetiva, varia de pessoa para pessoa, em que o cuidado de enfermagem, embora seja processual, objetivo e real, passa a depender da relação, transcendente ao mundo físico, material, para conectar-se ao mundo emocional e subjetivo, é dizer, transcende para uma sensação mais elevada do self. Ou seja, sempre há influência de um indivíduo sobre outro, influência esta centrada nos conceitos humanísticos do cuidado, olhando para as três dimensões do indivíduo: a biopsicológica, espiritual e a sociocultural. Os modelos teóricos embasam essa prática, porém, segundo Crivaro, Almeida e Souza (2007), se não houver uma associação eficaz entre o modelo teórico e a práxis, podem surgir conflitos que impedem a relação e o cuidado humanos.

Para o cuidado é essencial que exista um indivíduo responsável por desenvolver as situações de cuidar, o cuidador (Vieira, 2011). Este profissional é quem realiza o cuidado e estabelece as condições necessárias para que o outro desenvolva a si mesmo, ou seja, favorece oportunidades para que a pessoa cuidada demonstre suas capacidades, o que pressupõe interação, comprometimento, afetividade, empatia e empenho como componentes essenciais do cuidar (Floriano et al., 2012).

No contexto do envelhecimento da população, observa-se que com a melhoria das políticas públicas e a alteração no perfil populacional, diversos indivíduos vivenciam seu envelhecimento com saúde e condição física preservada, mantendo suas atividades de vida diária (AVDs), entretanto, há também casos de muitos indivíduos que envelhecem com limitações de saúde, devido às alterações fisiológicas naturais, hábitos de vida, entre outros fatores, ocasionando a incidência de condições crônicas que, consequentemente, podem levá-lo à perda de sua autonomia, dependência física, uso de múltiplas medicações, além de alterações emocionais e sociais (Trelha 
et al., 2006). Devido a esses fatores, o indivíduo poderá necessitar de auxílio oriundo de terceiros para que seja cuidado, podendo ser realizado por familiares, profissionais e/ou instituições. Nesse contexto, destaca-se o papel do cuidador de idosos (Gutierrez; Silva; Guimarães \& Campino, 2014).

A Política Nacional de Saúde do Idoso, aprovada pela Portaria 1.395/GM, de 10 de dezembro de 1999 define o Cuidador do Idoso como: "sendo a pessoa, membro ou não da família, que, com ou sem remuneração, cuida do idoso doente ou dependente no exercício das suas atividades diárias, tais como alimentação, higiene pessoal, medicação de rotina, acompanhamento aos serviços de saúde ou outros serviços requeridos no cotidiano - por exemplo, ida a bancos ou farmácias"-, dessa forma, ficam excluídas as técnicas e/ou procedimentos exclusivos e que são identificados nas profissões legalmente estabelecidas, particularmente na área da Enfermagem (COREN, 2015).

$\mathrm{Na}$ literatura nacional e internacional, encontram-se principalmente a definição de dois tipos cuidadores: os cuidadores familiares ou denominados informais e os cuidadores formais. Os cuidadores familiares/informais são os familiares, amigos, vizinhos, membros de grupos religiosos e outras pessoas da comunidade, que assumem a responsabilidade de prestação de cuidados ao indivíduo dependente no domicílio, garantindo-lhe suporte, desde cuidados básicos, como alimentação e higiene, e outras atividades como ir ao supermercado e realizar tarefas financeiras, sem ser remunerado para realização dessas atividades (Areosa et al., 2014).

Já os cuidadores formais são remunerados para exercer tais cuidados, prestando assistência na casa do paciente ou em instituições, mas que possuem pouco poder de decisão em relação ao indivíduo cuidado, pois cumprem as tarefas delegadas pela família ou pelos profissionais de saúde que os orientam (Areosa et al., 2014).

Os cuidadores formais, assim denominados em alguns artigos e publicações científicas, têm ocupado um espaço significativo no cuidado ao idoso fragilizado ou dependente. Observam-se, na literatura, três contextos que são mais explorados no que tange ao lugar de atuação do cuidador formal, são eles: o domicílio, as instituições de longa permanência e os centros-dia. Sendo que o cenário domiciliar ainda é, entre os demais, o mais citado pela literatura. Em relação às diferentes atividades a serem realizadas por esses indivíduos destaca-se a assistência ao idoso, cuja abrangência ainda não é muito clara (Duarte, 2009). 
Duarte (2009) descreve o cuidador como o profissional que convive diariamente com o idoso, prestando- lhe cuidados higiênicos, ajudando com a alimentação, administrando medicação e estimulando-o com as atividades reabilitadoras, interagindo assim com toda equipe terapêutica.

Ribeiro (2015), em sua dissertação, discorre sobre a forma de contratação da família. $\mathrm{Ou}$ seja, para a autora, existem duas formas de contratação destes cuidadores de idosos formais: pela família ou através de empresas de atendimento domiciliar (também conhecidas como home care). Os custos com os salários variam de acordo com alguns fatores como, por exemplo, grau de dependência dos idosos, carga horária de trabalho, perfil do cuidador e município onde o trabalho será executado e, assim, variam de um a seis salários mínimos. Caso o idoso tenha necessidade de cuidados 24 horas, e a família não pode prover o cuidado diretamente, é necessária a contratação de uma equipe composta por quatro cuidadores, chamada popularmente de "escala doze por trinta e seis", desta forma, dois cuidadores revezam-se durante o dia e dois cuidadores realizam o revezamento durante a noite, o que encarece e elitiza o serviço (Ribeiro, 2015).

No Brasil, observa-se um aumento no número de empresas de atendimento domiciliar. Essas empresas ficam responsáveis pelo gerenciamento do cuidado e dos cuidadores de idosos nos domicílios. As famílias pagam diretamente às empresas que se responsabilizam por toda a parte trabalhista relacionada aos profissionais, bem como pela supervisão e avaliação de desempenho destes. Além disso, estas empresas podem oferecer às famílias, outros profissionais da saúde como, por exemplo, fisioterapeutas, fonoaudiólogos, nutricionistas, médicos, terapeutas ocupacionais, enfermeiros, gerontólogos, entre outros (Ribeiro, 2015).

\subsubsection{Necessidade da equipe interprofissional}

De acordo com Floriane e Schramm (2004), o crescimento do atendimento domiciliar no Brasil é recente e muito vem sendo discutido sobre este segmento de prestação de serviço, tanto no setor privado quanto no setor público. Trata-se de uma das modalidades da área da saúde com forte

tendência à expansão, não somente pelo aumento da população idosa, mas também pelo conforto oferecido ao paciente por ser tratado em seu ambiente de convívio.

Segundo Dal Ben (2005), a assistência domiciliar constitui-se como uma forma de atender a demanda de pacientes que apresentam doenças crônicas, com o objetivo de reduzir o risco de infecção hospitalar e evitar que o paciente perca o convívio familiar ou, que ainda, retorne à internação hospitalar, além de diminuir os custos com internações recorrentes. 
Neste panorama do cuidado domiciliar, a residência do idoso passa a ser um novo campo de trabalho para diversos profissionais da saúde, médicos, enfermeiros, nutricionistas, fisioterapeutas, psicólogos, técnicos e auxiliares de enfermagem, cuidadores de idosos, gerontólogos, entre outros. Assim, o âmbito domiciliar torna-se um cenário integrador do cuidado ao idoso, visando seu conforto, qualidade de vida e bem-estar. Observa-se, pela literatura, que o trabalho em equipe é a base para ações integrais na saúde e também para atender com qualidade às necessidades dos usuários de acordo com cada situação e a experiência adquirida (Oliveira; Spiri, 2006).

A abordagem do paciente no seu contexto biopsicossocial é facilitada, pois é atendido por todos os membros da equipe que também o envolve na resolução de seu problema e o incentiva à autonomia para os cuidados em saúde. A equipe presta assistência integral, efetiva, contínua e com

qualidade, além de considerar a perspectiva da família, por meio da abordagem interdisciplinar, há também planejamento de ações, organização do trabalho e compartilhamento das decisões (Oliveira; Spiri, 2006).

\subsubsection{A atuação do gerontólogo na equipe interprofissional}

O rápido crescimento da população idosa traz um acentuado impacto para a família e para o setor público, além de apontar para a necessidade de formação de profissionais capacitados, os quais lidam com esse novo universo, principalmente nos âmbitos acadêmicos e profissionais. Diante desta realidade, as universidades brasileiras estão cada vez mais empenhadas na promoção de alternativas de profissionais capacitados a atender a população idosa em diferentes contextos (Falcão; Lopes, 2010).

No Brasil, há cursos de pós-graduação em Gerontologia e Geriatria, em nível de especialização, mestrado e doutorado. Recentemente, a novidade é referente aos primeiros cursos de graduação em Gerontologia. O primeiro deles foi iniciado em 2005, pela Universidade de São Paulo (USP). Em seguida, a Universidade Federal de São Carlos (UFScar) também aprovou a iniciativa no ano de 2009 (Falcão; Lopes, 2010). Entre 2007 e 2010 foram criados dois cursos de Bacharelado em outras duas instituições no Estado de São Paulo, Faculdades Adamantinenses Integradas (FAI) e Centro Universitário Claretiano (CEUCLAR - Ensino Técnico de Nível Superior) (Melo; Lima-Silva; Cachione, 2015). 
Criar um curso e formar, em nível de graduação, um profissional com habilidades e competências para integrar a equipe de saúde com um olhar gerontológico a fim de participar das transformações do cuidado à saúde do idoso, certamente é uma necessidade emergente e urgente no país. Esta iniciativa institui um marco importante para a história da gerontologia no Brasil e abre novas perspectivas na educação brasileira (Melo; Lima-Silva; Cachione, 2015; Pavarini et al., 2009).

Neste cenário, o gerontólogo, com diploma de formação acadêmica superior de primeiro ciclo, é um profissional muito recente que emerge no Brasil e em outros raros países, como em Portugal, por exemplo, apenas na última década. A sua formação acadêmica distingue-se por comportar, em partes equilibradas, unidades curriculares das ciências sociais e humanas e das ciências da saúde. A formação tem ainda a particularidade de prepará-los para intervir em idosos em situação de debilidade ou dependência, assim como, em idosos gozando de plena saúde e de uma vida ativa. Neste último caso a sua intervenção assume um caráter preventivo e minimizador de risco (Pereira et al., 2012).

O Bacharel em Gerontologia é um profissional apto a realizar a gestão da velhice e do envelhecimento e desempenha funções associadas à área que garantem o gerenciamento adequado da saúde, qualidade de vida e bem-estar do idoso.

O grande aumento no número de idosos e da longevidade, a prevalência das condições crônicas e os novos arranjos familiares supracitados, geram desafios que o gerontólogo irá enfrentar, a fim de priorizar a busca por soluções associadas à excelência do cuidado e a manutenção da qualidade de vida, além do gerenciamento adequado dos recursos humanos e financeiros (Pavarini et al., 2009).

Segundo Pereira (2008), a formação em Gerontologia está assentada em três pilares básicos: médica/cuidados de saúde; psicológica; e social/organizacional. Destaca ainda, que sua formação é generalista, tendo um conhecimento amplo nas áreas da saúde, social, psicológica e educacional.

A implantação do curso de graduação em Gerontologia proporcionará um número maior de profissionais preocupados com o tema e dispostos a criar, planejar, desenvolver e avaliar formas de apoio ao idoso, seus cuidadores e familiares. Os profissionais graduados estão capacitados a desenvolver ações de promoção do envelhecimento saudável, qualidade de vida, saúde e bem-estar, contribuindo para que o envelhecimento populacional seja um problema menos discrepante em nossa sociedade. 
Gerenciar o cuidado das pessoas idosas com doenças crônicas e com limitações exige conhecimento técnico assistencial, administrativo, além da capacidade em técnicas de resolução de problemas (Ministério da Saúde, 2006).

A formação acadêmica do gerontólogo permite que este profissional possa atuar no cuidado domiciliar, para contribuir com o gerenciamento do processo saúde-doença, reduzir os agravos inerentes ao processo de envelhecimento, melhorar continuamente a saúde, qualidade de vida e bem-estar do idoso, contribuindo assim, em alguns momentos também, no processo de morrer, visando uma morte digna ao idoso.

Desta forma, com esta pesquisa pretende-se responder algumas perguntas às quais incentivaram o estudo: Quais motivações levam os gerontólogos a atuar no cuidado domiciliar? Como os gerontólogos estão atuando no cenário domiciliar? Quais as dificuldades enfrentadas pelos gerontólogos nesta área de atendimento? Qual a visão dos cuidadores formais sobre a gestão do gerontólogo no atendimento domiciliar? 


\section{JUSTIFICATIVA}

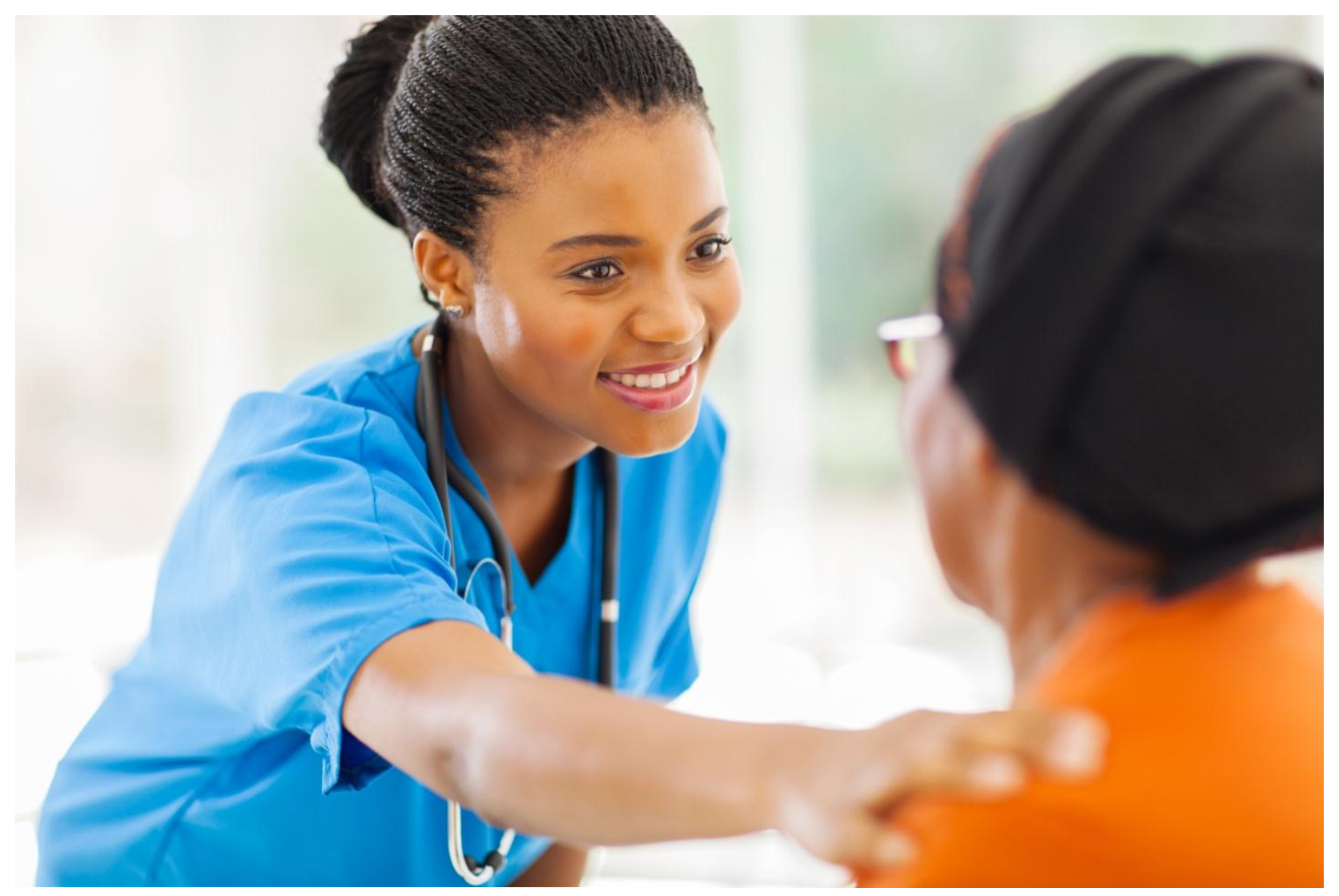

Fonte: Banco de Imagens Shutterstock, 2017 


\section{JUSTIFICATIVA}

O presente estudo justifica-se pela escassez de pesquisas nacionais que analisem o papel do gerontólogo como gestor de serviços de saúde oferecidos aos idosos, principalmente no cenário domiciliar. O estudo contribuirá para uma compreensão mais assertiva do atendimento prestado ao idoso em sua residência, bem como proporcionará aos profissionais envolvidos no cuidado domiciliar uma melhor reflexão sobre a atuação do gerontólogo bacharel na equipe interprofissional. 


\section{OBJETIVOS}

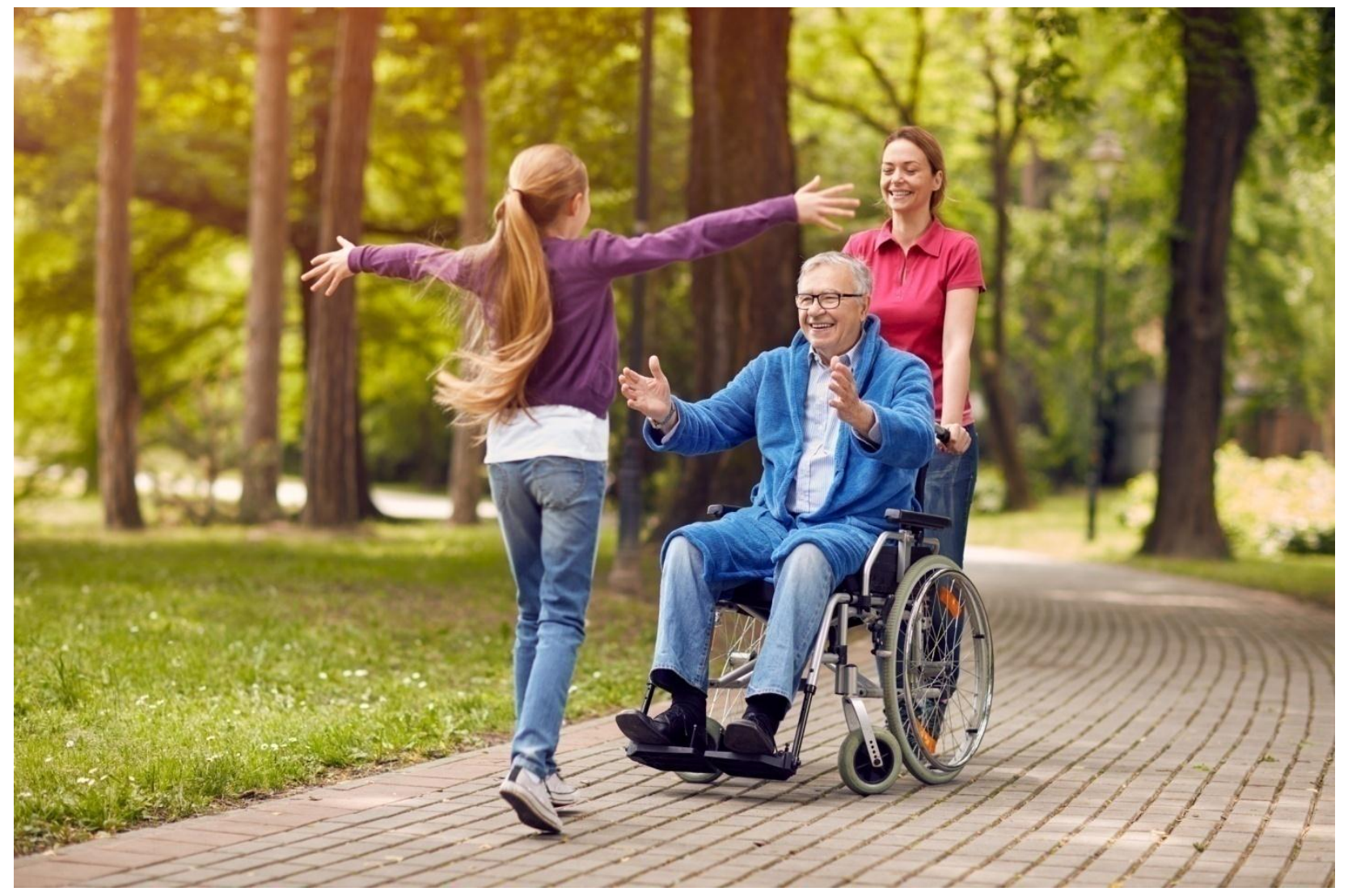

Fonte: Banco de Imagens Shutterstock, 2017 


\section{OBJETIVOS}

\subsection{OBJETIVO GERAL}

- Compreender o significado do gerontólogo como gestor do cuidado formal domiciliar, na perspectiva dos gerontólogos e cuidadores formais envolvidos diretamente no cuidado ao idoso.

\subsection{OBJETIVOS ESPECÍFICOS}

- $\quad$ Apreender, a partir das motivações do cuidador, o significado de atuar com o gerontólogo no cuidado domiciliar;

- $\quad$ Apreender, a partir das motivações do gerontólogo, o significado de sua atuação no cuidado domiciliar;

- Apontar as possíveis dificuldades do cuidador em trabalhar com o gerontólogo no atendimento domiciliar;

- Identificar as dificuldades de trabalhar como gerontólogo na gestão do atendimento domiciliar. 


\section{MÉTODO}

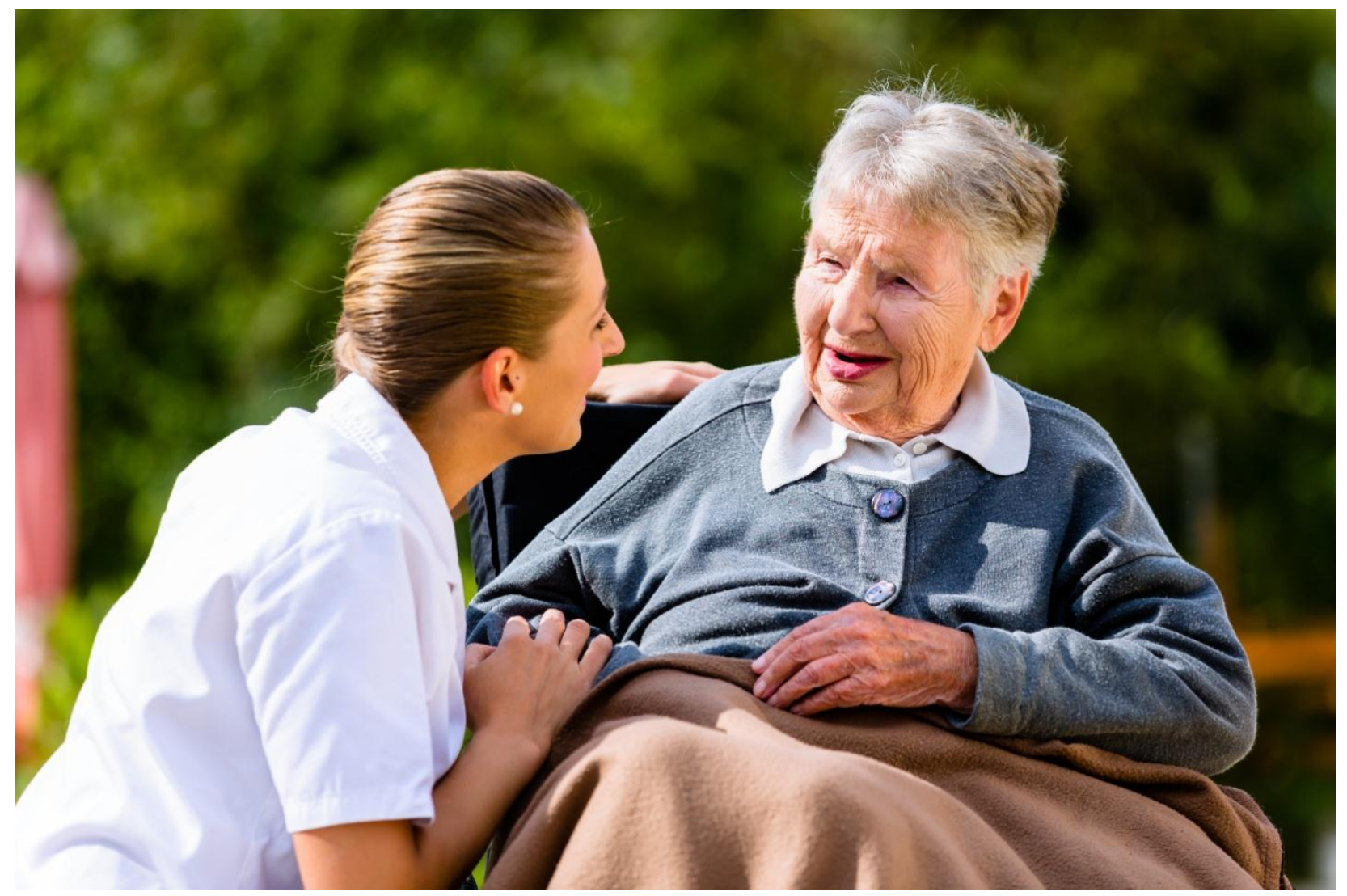

Fonte: Banco de Imagens Shutterstock, 2017 


\section{MÉTODO}

\subsection{REFERENCIAL METODOLÓGICO}

A pesquisa é qualitativa e tem como referencial metodológico a Fenomenologia Social de Alfred Schütz. Essa teoria fundamenta-se no indivíduo que vivencia a experiência e no significado que este atribui à experiência, dentro da sociedade a qual está inserido (Schütz, 1972). Para o autor, as experiências do indivíduo constituem a base de suas ações (Castro, 2012).

Olhando através da perspectiva de Schütz o cuidado é uma ação vivida individualmente, mas que está inserida no mundo da vida social. Baseia-se em relações intersubjetivas, sendo significadas e ressignificadas a partir do tipo de relação estabelecida com o outro. O cuidado profissional implica um tipo de relação social específica entre os sujeitos que dela participam. A Fenomenologia Social de Alfred Schütz constitui uma possibilidade de se pensar, fundamentar e desenvolver a ação de investigar, tendo como eixo norteador as relações sociais estabelecidas no contexto social (Jesus et al., 2013).

A análise das entrevistas/depoimentos dos participantes deste estudo possibilita a identificação e a descrição dos significados da ação - a categorização - com consequente compreensão do fenômeno estudado. As categorias resultantes do estudo constituem sínteses dos diferentes significados da ação que emergem das experiências dos participantes entrevistados. Tais categorias expressam os aspectos relevantes de ações que implicam os fenômenos sociais, tais como se apresentam no mundo social e envolvem tanto a reflexão dos sujeitos como a visão do pesquisador (Jesus et al., 2013).

Para Schütz, a ação origina-se na consciência para em seguida ser projetada ao futuro. Este projeto torna-se antecipado pela imaginação a partir das motivações. Schütz (1974), em sua teoria da Motivação, define que o motivo é o objetivo almejado a conquistar com a ação e o entende a partir de duas ordens definidas como: motivos porque e motivos para.

Segundo Schütz (1972), o motivo para está voltado a uma ação futura, fundamenta-se no contexto de significado que é construído ou se constrói sobre o universo das experiências disponíveis no momento da projeção da ação, sendo essa categoria essencialmente subjetiva, somente o sujeito pode definir o seu projeto de ação, seu desempenho social.

O motivo porque se estrutura e constitui uma espécie de acúmulo de conhecimentos sociais que são adquiridos ao longo da vida advindos da experiência pessoal ou recebidos por herança cultural. Esta série de experiências vividas, acumuladas e gravadas explicita e explica suas ações. 
Após o ato, estas ações podem ter um processo de reflexão, o que se torna acessível ao pesquisador (Schütz, 1974).

Segundo a Teoria da Motivação de Schütz, é possível compreender as relações sociais que estão profundamente ligadas às motivações dos indivíduos, podendo explicar os fenômenos sociais e, desta forma, a compreensão dos motivos para e motivos porque de uma ação específica. Para Jesus et al. (2013) a fala dos sujeitos quanto à sua motivação constitui a exteriorização de suas intencionalidades, as quais são captadas pelo pesquisador ou pelo profissional durante a entrevista.

Para que o pesquisador possa melhor observar a ação social, que é essencialmente subjetiva faz-se necessário agrupar as informações que somam os motivos para e os motivos porque do sujeito no mundo social - tipificação (Silva, 2013). A tipificação refere-se a um esquema conceitual que reúne as vivências conscientes e comuns de uma pessoa ou de um grupo no mundo social e, a partir dela, constrói-se o tipo vivido desta pessoa ou do grupo estudado.

\subsection{LOCAL DE ESTUDO}

A pesquisa foi realizada em três ambientes. No domicílio onde o idoso recebia atendimento, na instituição/empresa a qual os gerontólogos e cuidadores estavam vinculados, ou em um local apropriado e indicado pelo participante, livre de interferências. Todas as residências, empresas e locais pré-selecionados estavam localizados na cidade São Paulo.

\subsection{PARTICIPANTES DA PESQUISA}

Foram investigados 20 participantes, sendo 15 cuidadoras formais e cinco gerontólogas. Este número representa uma estimativa do total de gerontólogos atuantes na assistência domiciliar dentro da cidade de São Paulo. Como critérios de inclusão os gerontólogos (Bacharéis em Gerontologia) deveriam: a) Estar vinculados a alguma empresa que presta atendimento domiciliar a, no mínimo, seis meses; e b) Atuar direta e presencialmente no cuidado ao idoso. Já os cuidadores deveriam: a) atender aos pacientes de maneira formal; e b) serem supervisionados presencialmente por gerontólogos a, no mínimo, seis meses. 


\subsection{COLETA DE DEPOIMENTOS}

Os depoimentos foram coletados por meio de perguntas norteadoras (Apêndice A e B). Inicialmente, foi realizada uma pesquisa por telefone a fim de levantar quais empresas tinham a gestão gerontológica. Em seguida, o contato pessoal foi estabelecido com as empresas de cuidadores de idosos que alegaram ter o gerontólogo na gestão do cuidado domiciliar. O objetivo do contato era apresentar a pesquisa aos responsáveis e solicitar a aplicação da entrevista com os cuidadores e gerontólogos. Participaram da pesquisa cinco empresas de cuidadores de idosos.

Para obtenção dos depoimentos utilizou-se a entrevista de abordagem fenomenológica. Baseada na empatia e na intersubjetividade presentes no momento de encontro entre o pesquisador e a pessoa participante da pesquisa. Buscam-se através dos depoimentos a descrição da experiência do indivíduo referente ao objeto de estudo e a compreensão essencial do fenômeno estudado.

A duração de cada entrevista foi de, aproximadamente, 40 minutos, considerando o contato inicial, a apresentação da pesquisa e a entrevista propriamente dita.

Todos os depoimentos foram coletados pela própria pesquisadora, no período de fevereiro de 2017 a agosto de 2017.

\subsection{ANÁLISE DE DADOS}

Os depoimentos foram analisados qualitativamente, sob o olhar da Fenomenologia Social de Schütz, que busca descrever os processos sociais e compreender o mundo em seu significado intersubjetivo, analisando assim as relações mútuas que envolvem as pessoas. Schütz aborda uma estrutura de significados na vivência intersubjetiva da relação social, procurando entender não puramente o individual, mas também as ações sociais (Schütz, 1972; 1974).

Foi realizada a categorização dos significados a partir da redução fenomenológica. Para tanto, seguimos as indicações de pesquisadores em fenomenologia social (Jesus et al., 2013) quanto à organização e categorização do material obtido.

Assim, foram realizadas leituras minuciosas das entrevistas transcritas e posteriormente criadas as categorizações de acordo com as unidades de significado. Tais categorias foram divididas em motivos porque e motivos para e em seguida, foi realizada a análise compreensiva destas categorias, utilizando como base para interpretação do conteúdo o olhar do Referencial Teórico Filosófico de Alfred Schütz. 
Essas categorias são denominadas concretas e definidas como construções teóricas, as quais refletem, objetivamente, os significados da ação dos participantes da pesquisa. A partir da tipificação, baseada na análise e agrupamento das categorias construiu-se o tipo vivido dos gerontólogos e dos cuidadores formais.

\subsection{QUESTÕES ÉTICAS}

Os princípios éticos desta pesquisa estão fundamentados nas normas da Associação de Antropologia, de acordo com a Resolução n466/12 sobre as Diretrizes e Normas Regulamentadas de pesquisa em seres humanos (Conselho Nacional de Saúde, 2012). Este projeto foi aprovado pelo Comitê de Ética da Escola de Artes, Ciências e Humanidades da Universidade de São Paulo, CAAE: 55497716.7.0000.5390 (Anexo A). Em fevereiro de 2017 iniciou-se a coleta de dados.

Todos os participantes assinaram o Termo de Consentimento Livre e Esclarecido (TCLE) (Apêndice C e D), sendo-lhes garantida a condição ética de participantes da pesquisa. Além disso, os participantes foram previamente esclarecidos sobre o objetivo do estudo, a manutenção do sigilo, o anonimato e o direito de participarem ou não desta pesquisa. Foram ainda orientados quanto ao risco mínimo existente pela sua participação.

Foi solicitada a permissão do uso do gravador nas entrevistas, o que possibilitou o registro integral dos depoimentos para posterior análise. O material gravado foi arquivado pela pesquisadora e será mantido por cinco anos.

Para preservar a identidade dos participantes, no decorrer da discussão, utilizamos códigos de identificação para citar os trechos de suas falas.

A seguir apresenta-se Figura I representando a pesquisa, Figura II representando o esquema metodológico da pesquisa realizada com os gerontólogos, Figura III representando o esquema metodológico da pesquisa realizada com os cuidadores formais, e por fim, a Figura IV representando a análise compreensiva da pesquisa. 


\section{Figura I - Representação da pesquisa}

\section{O GERONTÓLOGO COMO GESTOR DO CUIDADO FORMAL DOMICILIAR: UM OLHAR DA FENOMENOLOGIA SOCIAL}

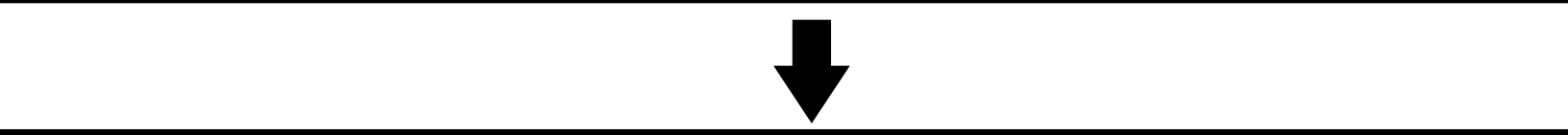

\section{OBJETO}

- Experiência do gerontólogo como gestor do cuidado formal domiciliar.

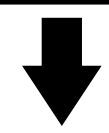

\section{INQUIETAÇÕES}

- Quais motivações levam os gerontólogos a atuar no cuidado domiciliar?

- Como os gerontólogos estão atuando no cenário domiciliar?

- Quais as dificuldades enfrentadas pelos gerontólogos nesta área de atendimento?

- Qual a visão dos cuidadores formais sobre a gestão do gerontólogo no atendimento domiciliar?

\section{OBJETIVOS}

\section{Geral}

Compreender o significado do gerontólogo como gestor do cuidado formal domiciliar, na perspectiva dos gerontólogos e cuidadores formais envolvidos diretamente no cuidado ao idoso.

\section{Específicos}

- Apreender, a partir das motivações do cuidador, o significado de atuar com o gerontólogo no cuidado domiciliar;

- Apreender, a partir das motivações do gerontólogo, o significado de sua atuação no cuidado domiciliar;

- Apontar as possíveis dificuldades do cuidador ao trabalhar com o gerontólogo no atendimento domiciliar;

- Identificar as dificuldades de trabalhar como gerontólogo na gestão do atendimento domiciliar.

Fonte: Jullyanne Marques Sousa Teixeira, 2017. 
Figura II - Representação do Esquema Metodológico (Gerontólogos)

\section{Participantes}

Gerontólogos vinculados a alguma empresa que presta atendimento domiciliar e atuam direta e presencialmente no cuidado com idoso.

\section{Local}

Na sede da empresa onde o gerontólogo atua, localizada, necessariamente, em São Paulo e/ou Grande São Paulo.

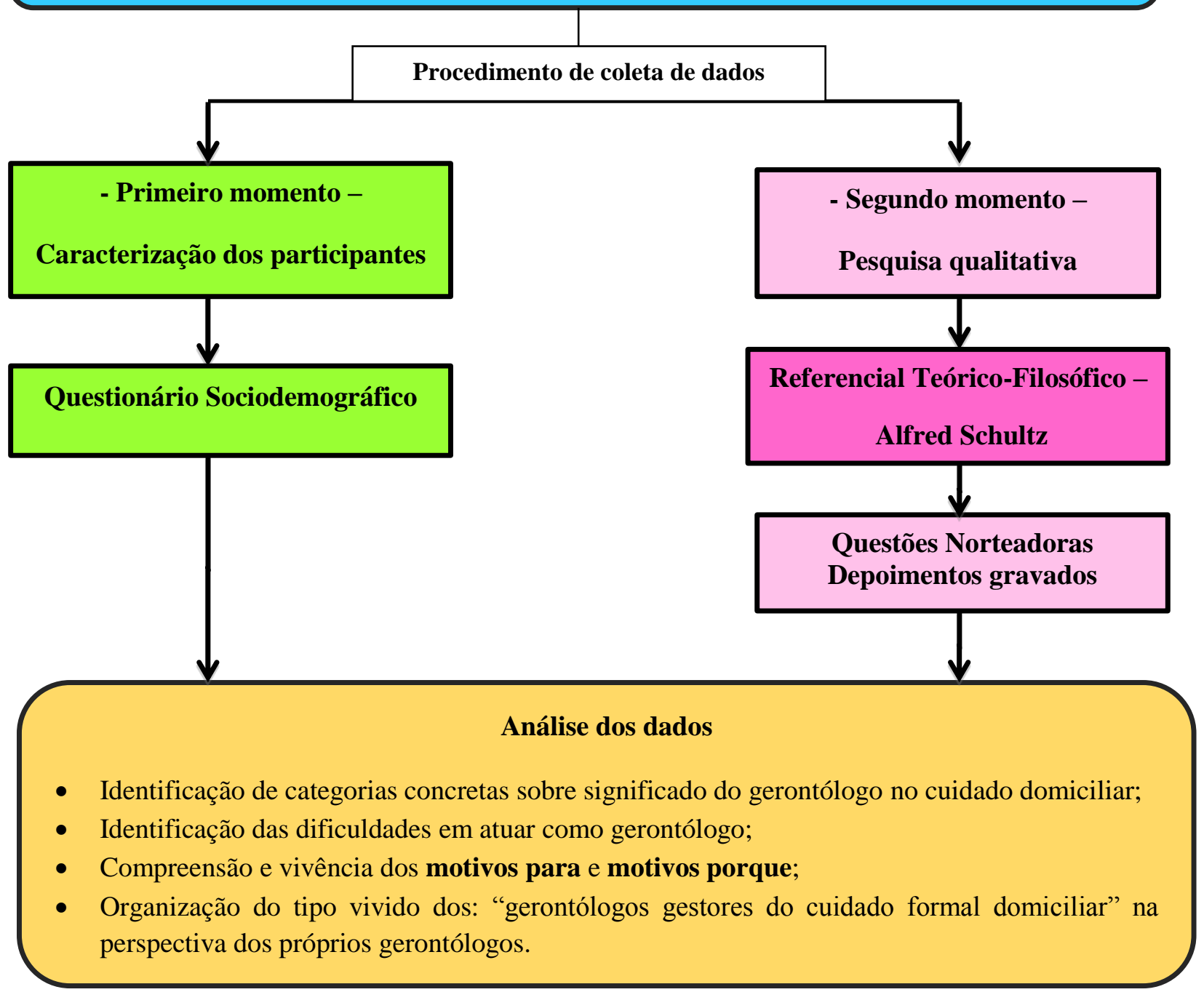

Fonte: Jullyanne Marques Sousa Teixeira, 2017. 


\section{Figura III - Representação do Esquema Metodológico (Cuidadores de idosos)}

\section{Participantes}

Cuidadores de Idosos vinculados a alguma empresa que presta atendimento domiciliar, que atendem aos pacientes de maneira formal e são supervisionados presencialmente por gerontólogos.

\section{Local}

Na sede da empresa que o cuidador atua, localizada, necessariamente, em São Paulo e/ou Grande São Paulo.

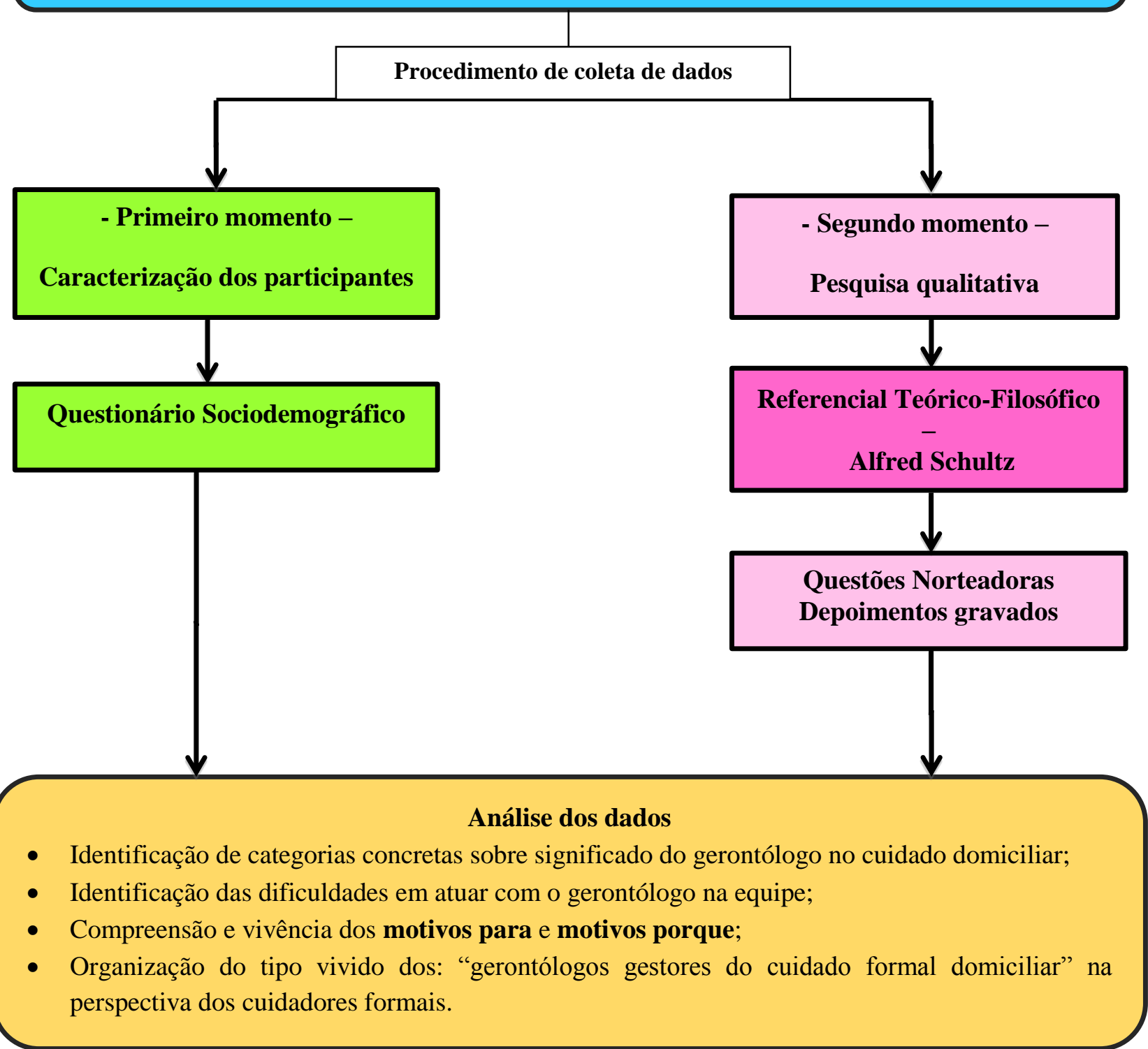

Fonte: Jullyanne Marques Sousa Teixeira, 2017. 
Figura IV - Esquema representativo da análise compreensiva

\section{ANÁLISE COMPREENSIVA}

\section{Experiência do gerontólogo como gestor do cuidado formal domiciliar}

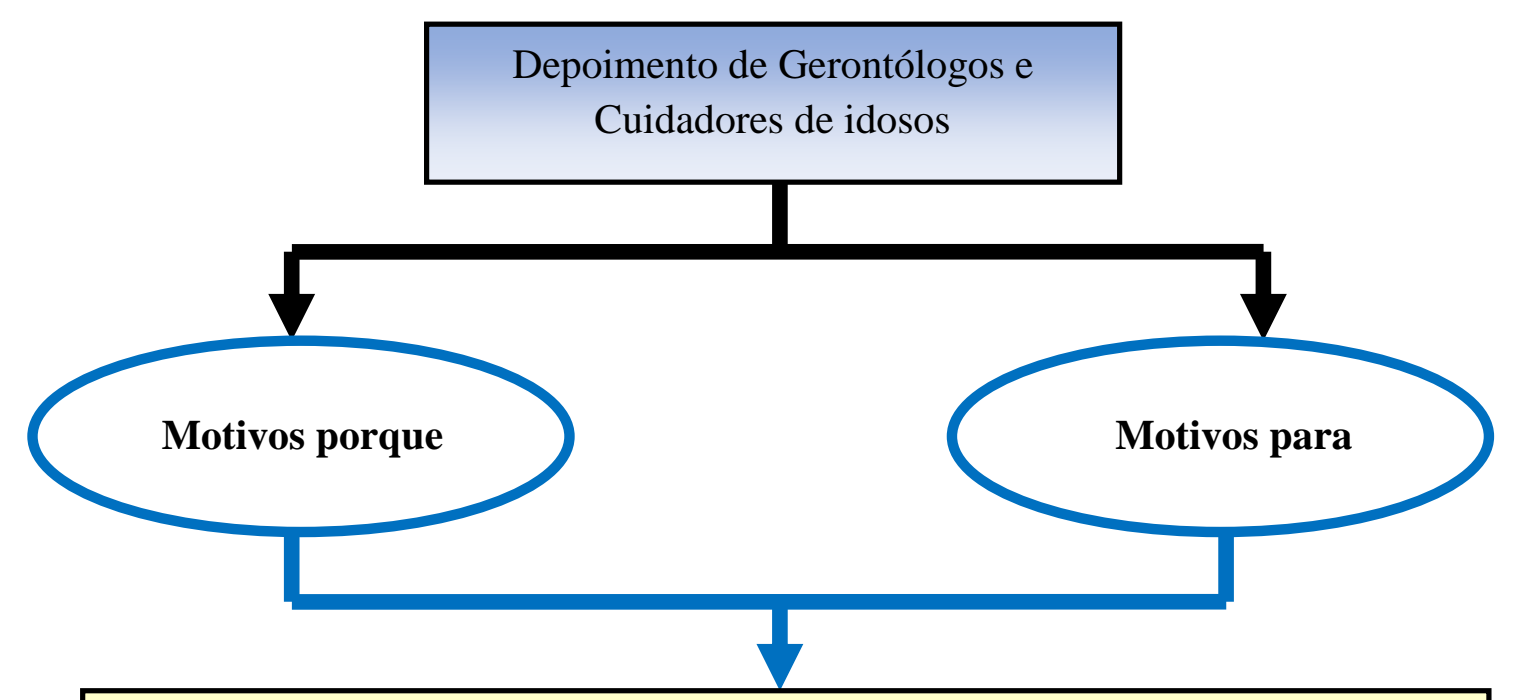

Categorias concretas do vivido

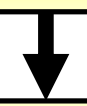

TIPO VIVIDO

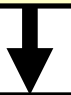

Compreender o significado do gerontólogo como gestor do cuidado formal domiciliar, na perspectiva dos gerontólogos e dos cuidadores formais envolvidos no cuidado ao idoso. 


\section{RESULTADOS E DISCUSSÃO}

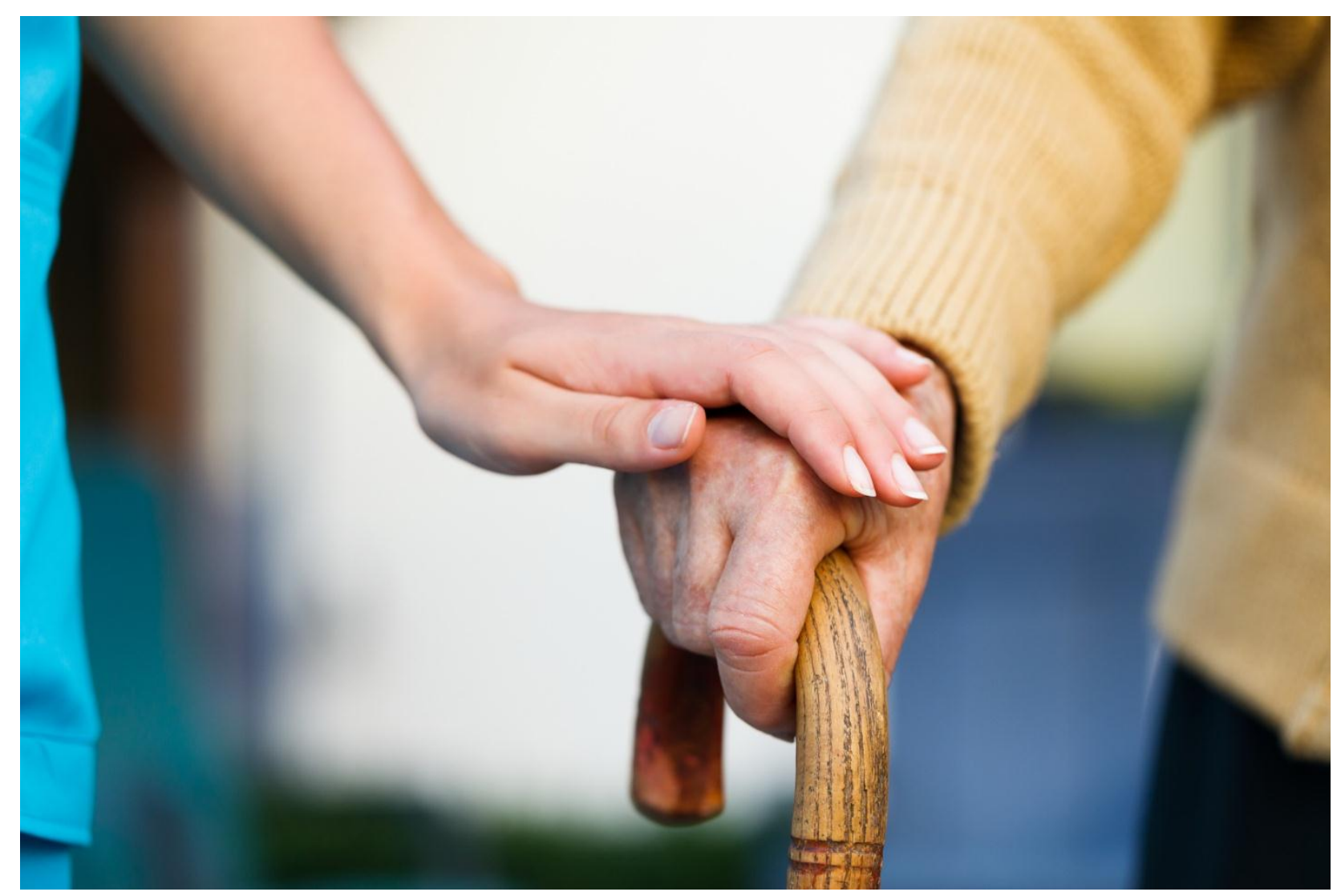

Fonte: Banco de Imagens Shutterstock, 2017 


\section{RESULTADOS E DISCUSSÃO}

\subsection{CARACTERIZAÇÃO DOS PARTICIPANTES}

Foram entrevistadas 15 cuidadoras, todas mulheres. A idade variou de 28 a 56 anos e o tempo de estudo das participantes foi, aproximadamente, de 11 a 14 anos. Somente duas cuidadoras não havia realizado curso de capacitação na área de cuidados ao idoso.

O tempo em que as cuidadoras estavam vinculadas à empresa e recebiam a supervisão direta e presencial do gerontólogo variou de seis meses a quatro anos. E o tempo de experiência das participantes de seis meses a oito anos.

Em relação aos gerontólogos, foram entrevistadas cinco gerontólogas, assim como as cuidadoras, também todas mulheres. A idade variou de 24 a 53 anos. Somente uma das gerontólogas entrevistadas tinha outra graduação, de Publicidade e Propaganda, cursada antes da Gerontologia. Três participantes já havia concluído a pós-graduação.

O tempo de vínculo das gerontólogas com a empresa de cuidado domiciliar variou de seis meses a três anos. E o tempo de experiência na área de cuidados domiciliares de seis meses a quatro anos.

\subsection{ANÁLISE COMPREENSIVA}

A compreensão da experiência do gerontólogo como gestor do cuidado formal domiciliar permitiu a organização e análise das categorias concretas, as quais reúnem o contexto de significados expressos na ação das participantes.

\subsubsection{Apresentação das categorias de Motivos Porque e Motivos Para}

\subsubsection{Motivos porque os cuidadores trabalham com o gerontólogo}

Apresentaremos a seguir os motivos porque os cuidadores optaram por trabalhar sob a supervisão gerontológica. Ou seja, a razão e o suas motivações a vivenciar esta ação. 
Quadro 1 - Motivos porque os cuidadores trabalham com o gerontólogo

\begin{tabular}{|c|} 
CUIDADORES \\
\hline MOTIVOS PORQUE OS CUIDADORES TRABALHAM \\
COM O GERONTÓLOGO \\
\hline Por indicação \\
\hline Poder administrar melhor o cotidiano \\
\hline Ter um profissional realizando a gestão do atendimento \\
\hline Evitar a insegurança e a solidão de ser cuidador \\
\hline Ter supervisão das atribuições do cuidador \\
\hline Não precisar tratar diretamente com a família \\
\hline
\end{tabular}

Fonte: Jullyanne Marques Sousa Teixeira, 2017

\subsection{Por indicacão}

Esta categoria refere-se aos cuidadores que começaram a trabalhar sob a gestão do gerontólogo porque receberam a indicação de outras pessoas, as quais os apresentaram às instituições que contam com gestão gerontológica, conforme o discurso abaixo:

Com o gerontólogo é mais próximo. Eu fui para a empresa por causa da minha amiga, né? Uma opção minha, mas junto com a minha amiga, pois na época que entrei na empresa ela já estava trabalhando aí eu pedi pra ela me indicar. (C.XIII.2.2)

\subsection{Poder administrar melhor o cotidiano}

De acordo com uma das cuidadoras participantes, quando o gerontólogo realiza a gestão do atendimento é possível administrar as tarefas do cotidiano com maior facilidade, que não envolvem, diretamente, o trabalho. Esta cuidadora referiu que quando o contrato era estipulado direto com a família, sem a intermediação de uma empresa e sem a gestão do gerontólogo, ela ficava muito tempo na casa do idoso, sem tempo para dedicar-se às suas tarefas pessoais. Neste caso, pode-se verificar que as experiências negativas vivenciadas pela cuidadora com as famílias, que a deixavam muito tempo na condição de trabalho, fez com que ela optasse por um serviço com gestão gerontológica. 
E eu queria trabalhar num local em que eu saísse, visse as pessoas. Que eu pudesse estudar, pegar condução, eu não aguentava mais ficar dia e noite no mesmo lugar. Aí ela começou a perguntar pra mim... Pediu que eu fosse lá fazer uma ficha, disse que trabalhava numa empresa "assim, assim, assado" e disse que tinha a gestão do gerontólogo e que, por isso, teria como eu estudar, que eu teria uma dinâmica pré-estabelecida de trabalho, que daria pra eu ter uma vida e aí foi quando me indicaram o primeiro paciente. (C.II.2.2)

\subsection{Ter um profissional realizando a gestão do atendimento}

Para algumas cuidadoras ter um profissional realizando a gestão do atendimento foi o motivo principal que as levaram a trabalhar com o gerontólogo, constituindo um motivo porque.

Foi pela oportunidade de trabalhar com um profissional que fizesse nossa gestão para que eu não me sentisse sozinha. (C.VIII.2.1)

Para Schütz (1972; 1974) os motivos porque se fundamentam no acervo de conhecimentos e experiências vivenciadas no cotidiano, desta forma, podemos entender que as cuidadoras que procuraram ter um profissional que realizasse a gestão do atendimento tiveram no passado experiências significativas referentes à gestão gerontológica.

\subsection{Evitar a inseguranca e solidão de ser cuidador}

Esta categoria refere-se aos cuidadores que em algum momento da vida sentiram-se sozinhos e inseguros sem a presença do gerontólogo e, por isso, optaram por trabalhar sob uma gestão:

Foi pela oportunidade de trabalhar com um profissional que fizesse nossa gestão, para que eu não me sentisse sozinha. (C.VIII.2.1)

Rodrigues et al. (2001) aponta a importância da participação dos cuidadores formais em atividades terapêuticas, como forma de amenizar o sofrimento vivenciado pelos cuidadores no trabalho. O mesmo autor em seu estudo encontrou que para muitos cuidadores o envelhecimento é 
representado como uma fase triste e de degradação, estas representações de envelhecimento influenciam negativamente nas atitudes e nos sentimentos dos cuidadores de idosos.

\subsection{Ter supervisão das atribuiç̃̃es do cuidador}

Devido à dificuldade de regulamentar a profissão de cuidador de idosos, consequentemente, padronizar a formação desses profissionais e delimitar o escopo de suas funções, muitos cuidadores enfrentam problemas relacionados às questões trabalhistas. Observa-se em seus discursos que quando não existe uma supervisão efetiva dos cuidadores de idosos, problemas como esses se tornam comuns, conforme as falas a seguir.

Eu preferi trabalhar assim, porque a gente tem todo um apoio referente à família, porque às vezes eles abusam, às vezes você entra para fazer uma coisa e quando você vai ver já está fazendo outra. (C.XII.2.1)

...você entrou hoje na empresa, você vai descrever tudo aquilo que você vai fazer e é tudo certinho, com contrato. E na realidade, quando você vai trabalhar registrado pra alguém, direto, sem os gerontólogos supervisionando, não é isso que acontece, eles te contratam como cuidador e você termina sendo a empregada, fazendo comida, passando roupa, fazendo tudo. (C.XII.2.2)

No cenário brasileiro, não existe a padronização da formação deste cuidador, não existe uma lei que o regulamenta como profissional e, apesar de definido pela Classificação Brasileira de Ocupações (CBO) como pessoas que Cuidam de bebês, crianças, jovens, adultos e idosos, a partir

de objetivos estabelecidos por instituições especializadas ou responsáveis diretos, zelando pelo bem-estar, saúde, alimentação, higiene pessoal, educação, cultura, recreação e lazer da pessoa assistida (MTE, 2013). Não existe, ainda, de maneira concreta o que o cuidador pode ou não fazer, principalmente no âmbito de cuidado em saúde.

Através do site da CBO, é possível gerar um relatório o qual apresenta as atividades específicas do cuidador de idosos. Porém, mesmo com essa iniciativa da CBO de divulgar estas funções do cuidador, em seu cotidiano de trabalho há um limite tênue entre as atividades domésticas e os procedimentos realizados por profissionais de enfermagem. No primeiro caso, os familiares pedem para que o cuidador, além de assumir o cuidado ao idoso, também assuma as 
atividades com a casa como, por exemplo, fazer faxina, lavar e passar roupa. E no segundo caso, induzem o cuidador a realizar procedimentos de enfermagem.

Situações como essas oferecem riscos à saúde do idoso, além de riscos legais ao cuidador. Discussões acerca deste tema devem ser realizadas em âmbito nacional, por ora, podemos amenizar os agravos deste cenário através da gestão desses cuidadores, conforme vimos nos discursos, e também com formação adequada, a qual delimite o escopo das atribuições desse profissional e que, acima de tudo, esclareça aos cuidadores os riscos ao assumir funções de outra classe profissional.

\subsection{Não precisar tratar diretamente com a família}

Esta categoria mostra a procura do cuidador por um local de trabalho onde não seja necessário tratar com a família as questões referentes ao paciente/atendimento.

Eu procurei essa empresa, porque aqui você tem todo um apoio e você não trata diretamente com a família, você trata direto com o gerontólogo. (C.XII.2.3)

Para Batista (2013), o modelo que tem sido proposto de cuidado ao idoso compreende uma relação triádica, a qual engloba o próprio idoso, a família e o cuidador formal. Contudo, conforme observamos no discurso acima, alguns cuidadores optam por serviços que disponham de uma gestão gerontológica a fim de não tratar diretamente com o familiar. 


\subsubsection{Motivos para os cuidadores trabalharem com o gerontólogo}

Apresentaremos a seguir os motivos para os cuidadores trabalharem sob a supervisão gerontológica, considerando a ação social vivenciada pelos participantes. Para melhor compreensão das categorias, foi realizada uma subdivisão, relacionando-as com gestão gerontológica, cuidador, idoso e família.

Quadro 2 - Motivos para os cuidadores trabalharem com o gerontólogo

\begin{tabular}{|c|}
\hline CUIDADORES \\
\hline MOTIVOS PARA OS CUIDADORES TRA BALHAREM \\
COM O GERONTÓLOGO \\
Gestão Gerontológica \\
\hline Administrar as informações sobre o idoso \\
\hline Identificar e atender as necessidades do paciente \\
\hline Orientar o paciente e seus familiares \\
\hline Unir a equipe multiprofissional, familiares e cuidadores \\
\hline Realizar trabalhos administrativos \\
\hline Acompanhar presencialmente o atendimento realizado \\
\hline Acolher a equipe de cuidadores, familiares e paciente \\
\hline Cuidador \\
\hline Dar segurança aos cuidadores \\
\hline Auxiliar o cuidador no processo de adaptação com o paciente \\
\hline Dar suporte integral e eficaz aos cuidadores \\
\hline Orientar a equipe de cuidadores \\
\hline Apoiar no processo de luto \\
\hline Idoso \\
\hline Zelar pelo cuidado à saúde do idoso \\
\hline Adaptar o ambiente para a segurança do idoso \\
\hline Família \\
\hline Não precisar tratar diretamente com a família \\
\hline Gerenciar os conflitos familiares \\
\hline
\end{tabular}

Fonte: Jullyanne Marques Sousa Teixeira, 2017

\subsection{Administrar as informacões sobre os idosos}

Para alguns cuidadores que participaram da pesquisa, o gerontólogo contribui para uma comunicação mais eficaz em relação às questões relacionadas ao idoso, pois o profissional 
administra as informações que advém dos familiares, equipe multiprofissional, cuidadores e do próprio idoso.

A gerontóloga dá um seguimento, por exemplo, ela chega aqui deixa escrito o que tem que fazer e todas nós seguimos e ninguém vai falar não, não vou fazer isso. (C.IX.14.10)

Quando eu preciso de alguma informação, quando acontece alguma coisa com o paciente, eu sempre entro em contato pra manter ele informado. (C.X.7.4)

Para Melo, Lima-Silva e Cachione (2015), considerando as demandas advindas do cuidado ao idoso, o gerontólogo deve compreender, criar, gerir, desenvolver e avaliar formas de apoio ao idoso e seus cuidadores familiares e profissionais, considerando as questões biológicas, psicológicas e sociais da velhice. Neste cenário, compreende-se que o gerontólogo deverá dialogar com todos os envolvidos no cuidado ao idoso, apoiando-os em suas necessidades, administrando e avaliando, continuadamente, o cuidado prestado.

\subsection{Identificar e atender as necessidades do paciente}

Alguns cuidadores relataram que os gerontólogos são capazes de identificar e atender às necessidades apresentadas pelo idoso no decorrer do atendimento.

...assiste à condição do paciente, numa totalidade, de todas as necessidades do paciente. (C.XIV.6.1)

De acordo com Lima (2009), o profissional gerontólogo é capaz de auxiliar o idoso e seus familiares em relação às suas necessidades assistenciais, de auxiliar o planejamento, acompanhamento e avaliação dos resultados obtidos. O gerontólogo acompanhará o idoso durante o atendimento, para minimizar os riscos, as dificuldades e para contribuir com o envelhecimento digno e saudável.

\subsection{Orientar o paciente e seus familiares}


Uma das cuidadoras apontou a importância do gerontólogo na orientação dos pacientes e seus familiares, conforme podemos observar na frase abaixo.

Imagina uma pessoa que fica perdida? A maioria dos pacientes que eu cuidei, ou mora com uma pessoa que não fica lá com ele, ou mora sozinha. Eles necessitam de ajuda, muitas vezes eles não têm informação nem pra saber como eles mesmos cuidam deles. Então, mesmo que eles precisem de uma cuidadora por um determinado período, quem vai orientá-lo senão o gerontólogo? Às vezes, ele nem conhece as próprias necessidades. Então eu acho que o gerontólogo é muito importante para o paciente. (C.II.8.10)

Duarte e Diogo (2005) partem da premissa que o cuidado não é exclusivo da enfermagem, ou áreas relacionadas à saúde, ao contrário, também é responsabilidade do sujeito cuidado, sua família e/ou cuidadores. As autoras também destacam a importância da família no processo de prestação de cuidados ao idoso.

No entanto, algumas famílias, apesar de presentes e ativas neste processo, não executam as atividades relacionadas ao cuidado, como é o caso das que dispõem de um cuidador formal. Cabe ao profissional gerontólogo neste cenário, orientar e apoiar a família, visando minimizar o desgaste emocional, colocando a família em contato com questões referentes ao processo de envelhecer e contribuindo para uma maior efetividade na resolução de problemas relacionados ao atendimento.

\subsection{Unir equipe multiprofissional, familiares e cuidadores}

Algumas cuidadoras referem que o trabalho do gerontólogo facilita a comunicação entre os membros da equipe, entre estes e os familiares. Isso porque o gerontólogo realiza uma intermediação das informações, sabendo relacionar-se com todos os envolvidos no cuidado do idoso.

...outra vantagem é que ela é a ponte de união entre uma cuidadora e outra. (C.III.10.10)

ela seria como se fosse uma espécie de mediadora, entre a gente e a família da paciente. Então assim, a gerontóloga é como se fosse uma ponte de ligação, entre nós cuidadoras e a família, ela 
...seria uma ponte, quando nós estamos precisando de alguma coisa, ela nos auxilia perante a família. (C.VII.6.7)

De acordo com o Projeto lei $n^{\circ}$ 6.764, de 2016, que dispõe acerca da Regulamentação do Profissional Gerontólogo (Brasil, 2016), está entre as atividades do gerontólogo: promover a integração de equipes multiprofissionais que prestam assistência às pessoas idosas. Neste contexto, inclui-se também a família que atua como elemento terapêutico para o paciente.

O gerontólogo, com sua formação generalista e integrada sobre o fenômeno do envelhecimento e da velhice, consegue transitar por todos os contextos de cuidado que envolve o idoso, criando vínculos com os profissionais e os familiares.

\subsection{Realizar trabalhos administrativos}

Segundo alguns cuidadores, o trabalho realizado pelos gerontólogos não se restringe à área assistencial, pois, conforme relatado nas entrevistas, os gerontólogos também assumem responsabilidades administrativas, principalmente às que estão ligadas à gestão do cuidador. Observa-se, nos discursos obtidos, a importância que o cuidador dá para esta atividade.

Dentro da empresa, além de todos esses serviços com o paciente e o cuidador, o gerontólogo também ajuda fazendo relatório, planilha, pagamentos, vendo se a cuidadora está no horário, qual a pontualidade do cuidador. (C.IV.6.15)

...o gerontólogo ajuda na gestão da nossa escala, isso é fundamental. (C.XII.14.20)

No estudo realizado por Cornélio (2010) com 40 cuidadores formais atuantes numa instituição de longa permanência, localizada no interior de São Paulo, foi identificado que a presença de estresse estava associada à organização e às condições do trabalho caracterizado por cansaço, carga horária extensa, trabalhar sozinho, falta de tempo, burocracia, fluxo do serviço, falta de recursos materiais e/ou problemas de relacionamento com a chefia ou equipe.

Neste sentido, o trabalho executado pelo gerontólogo, a fim de obter efetividade e atender integralmente ao cuidador, deverá englobar não apenas o cuidado com o idoso, mas também o 
cuidado com o cuidador e com as questões relativas ao seu trabalho. Evitando situações de desorganização e estresse.

\subsection{Acompanhar presencialmente o atendimento realizado}

Esta categoria refere-se à motivação que os cuidadores têm ao receber a visita presencial do gerontólogo no domicílio. Uma das participantes relatou que a visita e acompanhamento do gerontólogo incentivam o cuidado mais assertivo ao idoso, conforme apontado nos discursos a seguir.

...gerontólogo está ali pra fazer visita nas semanas, então ele quer saber tudo o que está acontecendo, mesmo nos dias que ele não foi ele quer estar à parte de tudo. (C.IV.8.18)

É um acompanhamento muito importante, porque dá um incentivo para a gente, a gente fica mais atento, não é aquele trabalho que está relaxado, que está “a Deus dará”, a gente está diariamente tentando melhorar. (C.XIII.3.4)

\subsection{Acolher a equipe de cuidadores, familiares e paciente}

Algumas cuidadoras veem no gerontólogo um amigo, alguém que elas podem confiar e contar, que vão além das questões relacionadas ao paciente e/ou ao atendimento. O gerontólogo, de acordo com os discursos obtidos, está em contato com os familiares, pacientes e cuidadores, concentra as informações, contribui para uma comunicação mais assertiva e acolhe as necessidades dos envolvidos.

No meu caso, é uma pessoa que virou uma amiga, se fez minha amiga, como também é uma amiga da paciente, faz mais do que a própria profissão pede. (C.VI.7.11)

Segundo Gratão (2006), a complexidade da tarefa de cuidar implica que, muitas vezes, os familiares envolvidos deixem de lado o autocuidado, suas necessidades e a satisfação em viver. Os cuidadores formais enfrentam problemas relacionados à sobrecarga de trabalho e estresse (Cornélio, 2010). 
Essa sobrecarga relacionada à tarefa de cuidar, geralmente, deve-se à qualidade ou quantidade de demanda as quais ultrapassam a capacidade de desempenho, por insuficiência técnica ou de tempo, que a pressão e a responsabilidade no trabalho propiciam, principalmente, o aparecimento da exaustão emocional (Maslach et al., 2001).

O paciente vive o processo de adoecimento que traz consigo um fator emocional de regressão, no sentido de acentuar sentimentos de fragilidade, de dependência e insegurança. Em pacientes dependentes de cuidados domiciliares, somam-se ainda sentimentos de impotência, incompetência, autodesvalorização, revolta e intolerância (Gavião, 2005).

O gerontólogo é o profissional que estará em contato com estes três grupos supracitados, e que, de acordo com os depoimentos, tem a função de acolher e apoiar cuidadores, familiares e pacientes. Para Melo, Lima-Silva e Cachione (2015), o gerontólogo possui como foco a pessoa idosa, sua família e sua rede de suporte social, ademais, sua formação possibilita o lidar com demandas advindas do processo de envelhecimento como um todo.

\subsection{Dar seguranca aos cuidadores}

Esta categoria refere-se à motivação que os cuidadores têm de trabalhar com o gerontólogo, devido à segurança que lhes é transmitida. O gerontólogo com sua formação biopsicosocial em velhice e envelhecimento, consegue apoiar aos cuidadores em suas dúvidas, medos e dificuldades. Este fenômeno pode ser observado nas falas abaixo:

A segurança que você tem com o gerontólogo, é a insegurança que você tem sem. Porque tem coisas que, mesmo que a gente tenha feito o curso de cuidadora, que a gente não está capacitada e aí acaba assustando, então o gerontólogo é isso, eu sei que tem uma pessoa que está acima de mim, qualquer coisa que vir acontecer que eu me assustar, é só eu ligar e estar com ela. Eu tive muita insegurança sem o gerontólogo. (C.VI.14.18)

Me dá muita segurança, porque eu sei que tem alguém que tem um conhecimento maior do que o meu. (C.VI.3.4)

\subsection{Auxiliar o cuidador no processo de adaptação com o paciente}


Para os cuidadores, iniciar o trabalho na casa de um paciente novo muitas vezes é uma tarefa complicada, pois cada contexto exige uma forma diferente de lidar, cada paciente requer uma atenção diferenciada voltada à sua necessidade. Dessa forma, podemos observar, através dos depoimentos, que a gestão do gerontólogo e a orientação dada antes do início do atendimento, auxiliam os cuidadores no processo de adaptação com o paciente e sua família.

A gerontóloga me levou até a paciente, me explicou tudo pessoalmente, como ela era, como ela não era, se ela gostava de fazer algumas coisas ou não, me explicou sobre todos os cuidados ao falar, paciência, saber respeitar a individualidade da paciente, se ela quisesse sair eu levava, se ela não quisesse eu ia conversando calmamente, e ela ia indo. (C.IV.5.11)

Quando você pega um paciente que você não sabe de nada, ele está sempre ali para explicar. Sozinho não tem como você fazer nada. O gerontólogo vai te explicar, deixa a gente informada, passa sobre a família, o que a família gosta o que ela não gosta. (C.X.10.6)

\subsection{Dar suporte integral e eficaz aos cuidadores}

Ter a gestão do gerontólogo para muitos cuidadores é contar com um suporte que vai além dos cuidados técnicos, de acordo com as falas desta categoria, podemos observar que o suporte técnico/emocional que o gerontólogo fornece ao cuidador durante o atendimento é um dos motivos pelos quais eles continuam trabalhando sob esta supervisão, à medida que se sentem mais seguros e acolhidos.

...se você se comunicar com ele, imediatamente ele já te responde, já procura orientar, já de imediato, é resposta imediata pra sua dúvida, pro seu questionamento. (C.II.14.14)

...é algo que me deixa mais segura, eu sei que eu tenho o apoio, eu sei que qualquer coisa que vier acontecer eu tenho alguém que me dá um suporte. (C.VI.2.3)

Me dá suporte técnico, não só técnico, é uma pessoa que está sempre muito próximo do paciente. (C.VI.6.8) 
Para Pavarini et al. (2012), o curso de graduação em gerontologia teve como um dos objetivos criar um profissional com habilidades e competências para integrar a equipe de saúde com um olhar gerontológico, além de participar ativamente das transformações do cuidado à saúde.

\subsection{Orientar a equipe de cuidadores}

Para a grande maioria dos cuidadores que participaram da pesquisa, trabalhar com o gerontólogo é ter a oportunidade de receber orientação sobre o atendimento e sobre o paciente, orientações de cunho técnico e comportamental.

Alguns cuidadores sentem-se inseguros, mesmo tendo concluído o curso de capacitação em cuidados aos idosos, dessa forma, a orientação do gerontólogo transmite sabedoria e segurança para que eles possam lidar com as situações do dia a dia, conforme observamos nos discursos destacados.

Pra gente não confundir o que é pulsação com pressão, respiração. O gerontólogo sabe de tudo isso, ele estudou, sabe muito mais do que nós. Muita gente que fez curso, também não sabe, então precisa muito do gerontólogo. Particularmente pra mim é uma “mão na roda”. (C.IV.3.9)

O gerontólogo me ajudou muito, orientando, me falando como que eu tinha que tratar me comportar. Como que eu tinha que me comportar diante da reação ou comportamento da pessoa que às vezes muda. A idade muda e ele orienta como temos que nos comportar, agir e falar. (C.IX.5.4)

A educação em saúde deve ser prioridade não apenas aos cuidadores familiares como também para os cuidadores de idosos formais, pois trata-se de garantir a assistência segura e com qualidade, tendo em vista o despreparo de muitos deles (Cornélio, 2010). Verifica-se uma necessidade de educação contínua ao longo do atendimento, para que os profissionais se sintam apoiados em suas dúvidas.

\subsection{Apoiar no processo de luto}

Apesar de a maioria das cuidadoras entrevistadas terem experiência na área e realizado o curso de capacitação, algumas ainda relataram a dificuldade em lidar com o óbito do paciente, de 
acordo com os discursos, podemos observar que o gerontólogo fornece o apoio emocional e técnico no processo de morte e luto.

...e o apoio que ela dá né, quando o paciente está ali entrando em óbito você acaba entrando em desespero, principalmente se você está sozinha com ele e a função da gerontóloga ali é ajudar, te orientar e você acaba não se sentindo sozinha, né? Eu acho fundamental a força que a gerontóloga dá o apoio né...(C.XII.3.5)

Um estudo realizado com cuidadores formais de idosos apresenta que um dos momentos mais complicados da profissão é o falecimento/perda do idoso. Segundo a autora, a questão da perda/falecimento dos idosos ser tida como o momento difícil a ser enfrentado na profissão foi abordada pela maioria dos cuidadores entrevistados (Ferreira, 2012). Mais pesquisas sobre o luto do cuidador devem ser realizadas para uma maior compreensão do fenômeno e, principalmente, para que os profissionais da área saibam auxiliar aos cuidadores neste processo.

\subsection{Zelar pelo cuidado à saúde do idoso}

De acordo com o discurso das cuidadoras, um dos motivos para elas continuarem trabalhando sob a gestão do gerontólogo é por estarem diante de um profissional responsável por zelar pelo cuidado à saúde do idoso.

Eu vejo que é uma pessoa que está sempre preocupada com os remédios, com a administração dos medicamentos, se estão fazendo efeito, com a alimentação, com indicação de outros profissionais, médicos, preocupados com outras atividades para o idoso fazer, eu vejo o gerontólogo sempre preocupado. (C.I.6.5)

Ele cuida da parte do paciente, por ele ser idoso, né? Cuida de toda a parte da saúde, da nutrição, do desenvolvimento dele, se ele está fazendo as coisas de iniciativa própria, tudo isso, o desenvolvimento, o desempenho dele no decorrer do tratamento, porque a gente está ali com ele, né? Pra ver se está tendo alguma evolução. (C.V.6.2) 
Segundo Lima (2009), os gerontólogos, estão capacitados para o monitoramento das condições sociais e de saúde dos idosos de forma que sejam evitados ou postergados maiores agravos. A autora destaca ainda que os profissionais formados estão preparados para contribuir no desenvolvimento de um envelhecimento saudável, apoiar o cuidado e encorajar a participação ativa da família e do idoso nesse processo.

\subsection{Adaptar o ambiente para a seguranca do idoso}

Alguns gerontólogos auxiliam as famílias na adaptação do ambiente, garantindo uma melhor segurança e qualidade de vida ao idoso. Esta atividade desenvolvida pelo gerontólogo é apresentada no discurso dos cuidadores, conforme vemos abaixo:

...aquela família precisa de um gerontólogo, pra falar "olha, você tem que arrumar isso, o banheiro não pode ter tanto degrau”, era degrau pra entrar na banheira, degrau pra entrar no Box. (C.I.14.9)

...a questão da segurança da residência, dando suporte pra família, falando o que é bom e o que não é, acho que isso é muito importante. (C.XIII.8.7)

O processo de envelhecimento e a presença de doenças crônicas podem levar pessoas idosas a apresentarem dificuldades funcionais. Tais perdas funcionais podem reduzir a capacidade do idoso em executar as atividades de vida diária, aumentando o risco de acidentes e quedas e, consequentemente, diminuindo a qualidade de vida do idoso. A adaptação do ambiente advém da necessidade de ambientes que favoreçam a autonomia e independência do idoso e que reduzam os riscos de acidentes domésticos (Mello; Perracini, 2005).

O gerontólogo, por conhecer as necessidades específicas de cada idoso e suas habilidades funcionais, é capaz de planejar ambientes amigáveis ao usuário. Certamente, faz-se necessário o olhar de diversas disciplinas para garantir o sucesso da adaptação ambiental, pois é essencial a colaboração de diversos profissionais, entre os quais, arquitetos, assistentes sociais, fisioterapeutas, enfermeiros, psicólogos e terapeutas ocupacionais (Mello; Perracini, 2005).

\subsection{Não precisar tratar diretamente com a família}


Esta categoria refere-se aos cuidadores que preferem não tratar sobre os assuntos relacionados ao paciente diretamente com a família, ou seja, contam com o gerontólogo para obter informações, orientações e diretrizes sobre o atendimento. Para eles, ter o gerontólogo, concentrando as informações e sendo a única fonte de contato e gestão, facilita a organização do atendimento.

Porque aqui é assim: o gerontólogo determina como que vai ser e todas nós temos que seguir aquilo. Lá não, lá tinha momentos difíceis que a família toda intervinha e um falava uma coisa e outro falava outra e eu ficava no meio, não sabia, e eles não resolviam o que tinha que fazer e a gente ficava meio atordoada, era difícil, muito difícil. (C.IX.14.10)

\subsection{Gerenciar os conflitos familiares}

Alguns cuidadores trabalham sob a gestão do gerontólogo para que o mesmo possa intermediar e gerir os conflitos familiares que se manifestam, frequentemente, no decorrer do cuidado prestado. Conforme podemos observar nas falas abaixo:

... a gerontóloga teve uma participação grande, a família era muito difícil de lidar, foram gerando alguns transtornos e eu fui passando pra gerontóloga e fui mantendo a calma, pra poder não sair e abandonar o serviço. (C.XIII.5.5)

...pra mim é sempre administrar a crise da família, em primeiro, segundo e terceiro lugar. É sempre bom ter com quem contar pra pedir socorro. (C.I.10.8)

A família é obrigada a se reajustar para facilitar o enfrentamento da situação específica no âmbito doméstico. E os responsáveis são, cotidianamente, testados em sua capacidade de discernimento e adaptação à nova realidade, exigindo, além de dedicação, responsabilidade, paciência e, mesmo, abnegação (Luzardo et al., 2006).

A experiência de cuidar de idosos tem sido caracterizada como uma situação estressante que afeta a saúde física e psicológica do cuidador familiar, podendo este apresentar altos níveis de ansiedade, tanto pelo sentimento de sobrecarga quanto por constatar que a sua estrutura familiar está sendo afetada pela modificação dos papéis sociais (Vieira; Nobre et al., 2012). 
Situações como estas podem gerar conflitos entres os envolvidos e, por isso, os cuidadores formais sentem-se mais aparados quando podem contar com o gerontólogo para intermediar o conflito instalado na família.

\subsubsection{Motivos porque os gerontólogos trabalham no cuidado domiciliar}

Apresentaremos a seguir os motivos porque os gerontólogos optaram por trabalhar como gestores do cuidado formal domiciliar. Compreendendo os significados e motivos que os levaram a esta ação.

Quadro 3 - Motivos porque os gerontólogos trabalham no cuidado domiciliar

\begin{tabular}{|c|}
\hline GERONTÓLOGOS \\
\hline $\begin{array}{l}\text { MOTIVOS PORQUE OS GERONTÓLOGOS } \\
\text { TRABALHAM NO CUIDADO DOMICILIAR }\end{array}$ \\
\hline Acreditar no modelo de atendimento domiciliar \\
\hline Ter a demanda de clientes e cuidadores \\
\hline Acreditar no trabalho do gerontólogo \\
\hline Trabalhar diretamente com o idoso no domicílio \\
\hline Facilidade em conseguir emprego \\
\hline Experiência acadêmica \\
\hline Indicação profissional \\
\hline
\end{tabular}

Fonte: Jullyanne Marques Sousa Teixeira, 2017

\subsection{Acreditar no modelo de atendimento domiciliar}

Uma das gerontólogas entrevistadas referiu que o motivo porque ela começou a trabalhar na área do cuidado domiciliar foi acreditar no modelo de atendimento.

Porque eu acredito muito no modelo da pessoa idosa continuar na sua própria casa. (G.I.2.2)

Para a gerontóloga, o cuidado domiciliar permite que o idoso permaneça em contato com seu ambiente, seus valores e cultura. 
Porque você minimiza custos de uma série de situações, você ir pra uma ILPI, por exemplo, você descaracteriza o ambiente dela e quando você coloca essa pessoa em casa e faz uma gestão com uma equipe multiprofissional... (G.I.2.3)

\subsection{Ter a demanda de clientes e cuidadores}

Uma das gerontólogas entrevistadas, além de atuar no cuidado domiciliar, empreendeu e investiu na área. Para ela, o motivo que a levou para trabalhar neste cenário, foi o fato de ter recebido, anteriormente, a demanda. Assim, conforme observamos em seu discurso, a gerontóloga aos poucos foi adentrando na área, atendendo as demandas que surgiam.

...eu tinha já a demanda, e ela apareceu mais ainda na hora que eu coloquei, então assim, o primeiro cliente que veio, eu já tinha uma cuidadora, que por sinal já tinha cuidado desse cliente, entrei em contato com ela, a partir dela eu entrei em contato com mais duas. (G.I.4.5)

Melo, Lima-Silva e Cachione (2015) apontam que o gerontólogo não está apenas preparado para atuar em empresas de atenção domiciliar, como também pode criar e gerir empresas deste segmento com a disponibilização de profissionais para o cuidado com o idoso, cuidadores de idosos para realizarem o cuidado domiciliar diário do idoso e o acompanhamento gerontológico semanal, realizados por especialistas em envelhecimento e velhice, com formação em gerontologia.

\subsection{Acreditar no trabalho do gerontólogo}

Para uma das gerontólogas entrevistadas a motivação que a fez trabalhar com o cuidado domiciliar, foi acreditar no trabalho que o gerontólogo executa. Segundo a participante, o gerontólogo possui um olhar amplo e biopsicossocial em relação às questões da velhice e do processo de envelhecimento, tornando-o capaz de assumir a responsabilidade desta gestão.

...acreditar que o gerontólogo é um especialista na área do envelhecimento, que é um profissional diferenciado, com essa visão gerontológica, ampla, biopsicossocial, faz com que me incentive a trabalhar no cuidado domiciliar, pela importância que se mostra nesse cuidado. (G.II.2.4) 
O curso de graduação em Gerontologia veio numa perspectiva inovadora de criar uma nova categoria profissional com formação interdisciplinar. Este profissional conclui o curso com a formação necessária para compreender o processo de envelhecimento e atender esta população, baseado nos conhecimentos das ciências biológicas, humanas e exatas (Pavarini et al., 2012).

\subsection{Trabalhar diretamente com o idoso no domicílio}

O interesse de algumas gerontólogas em entender as funcionalidades do cuidado ao idoso no domicílio foi o que as motivaram a trabalhar na área. A vontade de ter contato direto com o idoso também compõe a categoria.

...eu queria ter o contato direto com o cliente, no caso o idoso. (G.II.2.2)

...na verdade eu queria entender como é essa rotina de home care. (G.III.2.1)

O imaginário vigente no senso comum de que gerontólogo apenas lidará com o idoso em seu ambiente de trabalho não é a realidade. O Gerontólogo poderá exercer sua prática profissional em contato direto ou indireto com a população idosa, tanto em contexto comunitário como institucional (Melo; Lima-Silva; Cachione, 2015). Sendo assim, quando se aspira trabalhar diretamente com o idoso, o profissional deverá procurar serviços que atendam esta expectativa, como pode ser observado nas frases acima.

Pereira (2010), em sua pesquisa realizada com graduandos de Gerontologia da Escola Superior de Saúde de Bragança, em Portugal, verificou que 43,9\% dos estudantes motivaram-se a ingressar no curso devido ao desejo de trabalhar com idosos, sendo que a maioria relatou ter experiência na prestação de cuidados, em especial para com os próprios avós. O que corrobora com a Teoria da Motivação de Schütz, a qual afirma que a ação do sujeito se fundamenta nos antecedentes, no acervo de conhecimentos e na experiência vivida no âmbito biopsicossocial da pessoa (motivos porque) (Jesus et al., 2013).

\subsection{Facilidade em conseguir o emprego}


O motivo pelo o qual uma das gerontólogas começou a trabalhar no cuidado domiciliar, foi à facilidade de conseguir o emprego nesta área. De acordo com a participante, esta área respondeu de maneira mais rápida à sua procura por emprego.

...logo que eи me formei eи comecei a procurar emprego e foi o setor que foi mais rápido para me oferecer uma proposta e, daí por diante, que eu acabei indo para mais de uma empresa de assistência domiciliar. (G.IV.2.3)

Melo, Lima-Silva e Cachione (2015) discorrem sobre os motivos da dificuldade de inserção do gerontólogo no mercado de trabalho como, por exemplo, a não regulamentação da profissão e a falta de clareza sobre o caminho que há entre a graduação e o mercado de trabalho. Apesar do discurso acima relatar uma situação contrária, é importante que seja transparecida a realidade atual e as dificuldades enfrentadas pelos bacharéis em gerontologia no início de sua carreira profissional.

\subsection{Experiência acadêmica}

Para uma das gerontólogas, seu interesse na área de cuidados domiciliares iniciou-se na graduação e estendeu-se para a vida profissional. A gerontóloga refere que esteve em contato com o tema durante a iniciação cientifica e TCC e, por isso, resolveu trabalhar na área.

Primeiro meu interesse desde a iniciação científica pelo tema de cuidadores e Alzheimer. (G.V.2.9)... Depois eu me apaixonei por este tema e segui ele no TCC. (G.V.2.10)

De acordo com a fenomenologia social de Schütz, a ação é interpretada pelo sujeito a partir de seus motivos existenciais, derivados das vivências inscritas em sua subjetividade, constituindo fios condutores da ação no mundo social. Aqueles que se fundamentam nos antecedentes, no acervo de conhecimentos, na experiência vivida no âmbito biopsicossocial da pessoa são denominados, como vimos, por motivos porque. Desta forma, a experiência e a vivência com o tema na graduação constituem como motivo porque da participante ter optado por trabalhar na área domiciliar e não em outra (Schütz, 1972;1974). 


\subsection{Indicacão profissional}

Uma das gerontólogas participantes começou a trabalhar no contexto domiciliar devido uma indicação realizada por outra profissional que não poderia dar continuidade ao cargo.

A minha entrada ocorreu por causa da indicação de outra gerontóloga que não poderia mais dar continuidade nesta empresa porque ela conseguiu outro trabalho e ela me indicou. (G.V.2.13) 


\subsubsection{Motivos para os gerontólogos trabalharem no cuidado domiciliar}

Apresentaremos a seguir os motivos para os gerontólogos trabalharem como gestores do cuidado formal domiciliar. Para melhor compreensão das categorias, foi realizada uma subdivisão relacionando-as com gestão gerontológica, cuidador, idoso, família e gerontólogo.

Quadro 4 - Motivos para os gerontólogos trabalharem no cuidado domiciliar

\begin{tabular}{|c|}
\hline GERONTÓLOGOS \\
\hline $\begin{array}{c}\text { MOTIVOS PARA OS GERONTÓLOGOS } \\
\text { TRABALHAREM NO CUIDADO DOMICILIAR }\end{array}$ \\
\hline Gestão Gerontológica \\
\hline Realizar a gestão gerontológica do atendimento \\
\hline Administrar o cuidado com o idoso \\
\hline Acompanhar presencialmente o atendimento realizado \\
\hline Administrar as informações sobre o idoso \\
\hline Liderar a equipe \\
\hline Unir equipe multiprofissional, familiares e cuidadores \\
\hline Gerenciar a escala da equipe de cuidadores \\
\hline Identificar e atender as necessidades do paciente e sua família \\
\hline Mediar e gerenciar o cuidado \\
\hline Supervisionar o cuidado \\
\hline Cuidadores \\
\hline Capacitar e orientar os cuidadores de idosos \\
\hline Dar suporte integral e eficaz aos cuidadores \\
\hline Idoso \\
\hline Adaptar o ambiente para a segurança do idoso \\
\hline Avaliar o idoso \\
\hline Ajudar a melhorar a saúde do idoso \\
\hline Ter contato próximo com o idoso \\
\hline Incentivar a autonomia e a independência do idoso \\
\hline Zelar pela segurança do idoso \\
\hline Família \\
\hline Dar orientação e suporte aos familiares \\
\hline Incentivar a família para um melhor cuidado \\
\hline Gerontólogo \\
\hline Divulgar a profissão de gerontólogo \\
\hline Ser valorizado como gerontólogo \\
\hline Aprender com as situações e ter resolutividade \\
\hline Ter mais flexibilidade e autonomia no trabalho \\
\hline Colocar os conhecimentos teóricos em prática \\
\hline
\end{tabular}

Fonte: Jullyanne Marques Sousa Teixeira, 2017 


\subsection{Realizar a gestão gerontológica do atendimento}

Esta categoria refere-se à motivação que as gerontólogas têm para trabalhar no cuidado domiciliar, realizando a gestão gerontológica do atendimento. Esta categoria foi uma das que mais surgiu no discurso das participantes.

O gerontólogo contribui pro cuidado realizando a gestão desse cuidado, identificando as demandas, tendo um olhar mais apurado, diferenciado, conseguir resolver os problemas e conflitos familiares, então eu acredito que o gerontólogo é um profissional capacitado e especializado no envelhecimento que consegue entender a heterogeneidade do idoso e as diferenças familiares, diferentes formas de lidar com a família e com o cuidado que será prestado. (G.II.9.24/25)

...então, o gerontólogo sendo um especialista e estando apto pra fazer essa gestão do cuidado me motiva a trabalhar no cuidado domiciliar. (G.II.2.50)

De acordo com Lima (2009), fazem parte das atribuições do gerontólogo: coordenar ações de assistência à saúde do idoso e sua família; atuar em equipe multiprofissional de atenção ao idoso; analisar, criticamente, a realidade de atenção ao envelhecimento propondo ações criativas para solucionar os problemas encontrados; além de levar em conta o perfil epidemiológico, os fatores sociopolíticos e culturais, a tecnologia, os equipamentos, os recursos disponíveis e necessários à prática profissional.

Duarte e Lebrão (2006) ressaltam que o cuidado gerontológico exige reavaliação ativa e constante, permitindo a adequação das metas no decorrer do cuidado prestado. O trabalho que o gerontólogo desenvolve é dinâmico e envolve a gestão do plano de cuidados traçado após a avaliação.

Podemos observar também que a gestão gerontológica realizada pelas participantes da pesquisa, vai além dos cuidados e atenção para com o idoso, o gerontólogo neste contexto atua diretamente com todas as questões referentes ao envelhecimento, velhice e cuidado.

\subsection{Administrar o cuidado com o idoso}

O gerontólogo, de acordo com o depoimento de algumas participantes, é o profissional responsável por administrar todas as demandas referentes ao cuidado do idoso. Cabe ressaltar, que não somente as demandas relacionadas à saúde, mas também aquelas relacionadas à higiene, lazer, segurança, qualidade de vida e bem-estar. 
...vejo a periodicidade do tratamento médico, agora dia 20 tem que fazer os agendamentos médicos pro mês seguinte, né?... Vejo a periodicidade de dentista, vejo a periodicidade de cabeleireiro, vejo a periodicidade dos serviços. (G.I.5.16/17)

...então se a gente sente que o idoso está precisando de fono a gente orienta "olha, sentimos a necessidade da inserção do profissional de fonoaudiologia, etc." E isso tudo vai dando um encaminhamento e uma segurança maior para a família e para o paciente.(G.V.9.42)

Fazem parte das atividades do gerontólogo: planejar, organizar, coordenar, executar e avaliar programas, serviços, políticas e modalidades assistenciais ao idoso, comunidade e família, com vistas à promoção do bem-estar e qualidade de vida dos assistidos (Brasil, 2016).

Observa-se através dos discursos que o profissional gerontólogo assume atribuições que seriam comumente associadas à família como, por exemplo, agendamento de consultas médicas, cabeleireiro e, entre outras.

A família enfrenta desafios importantes diante das demandas advindas da velhice, seja ela normal ou patológica. A reação de cada família em relação a esta fase do ciclo de vida muitas vezes depende dos relacionamentos, vínculos e padrões familiares anteriores a este momento (Falcão; Baptista, 2010). Neste cenário, cabe ao gerontólogo avaliar os vínculos familiares e entender quais serão as demandas e expectativas de cada família em relação ao cuidado.

\subsection{Acompanhar presencialmente o atendimento realizado}

Faz parte da rotina de todas as gerontólogas entrevistadas o acompanhamento presencial do atendimento. $\mathrm{O}$ que variou foi em relação à periodicidade com que as visitas ocorrem. De modo geral, as atividades executadas durante a visita não se alteraram muito, pois, todas as gerontólogas relataram que planejam a visita de acordo com a necessidade de cada idoso/família. Além disso, observa-se em seus discursos a preocupação em identificar as necessidades dos cuidadores formais e equipe da interprofissional.

...eu tenho as equipes nas casas e a cada 10 dias eu visito o paciente, ou menos, dependendo da situação. (G.I.4.8)

a rotina do gerontólogo é fazer as visitas pra identificar a demanda do cuidado, pra identificar a situação do paciente. (G.II.4.10) 
A maior parte do dia eu faço as visitas domiciliares ... E ligações, o tempo todo no telefone, inclusive no trânsito, junto com o cuidador, com familiar, com paciente, com o pessoal da empresa, enfermeiro. (G.III.4.6)

\subsection{Administrar as informacões sobre o idoso}

Faz parte das atribuições do gerontólogo administrar as informações sobre o idoso, aquelas recebidas do cuidador, familiares, equipe interprofissional e também do próprio paciente. Conforme alguns depoimentos, o gerontólogo organizará as informações para direcioná-las a fim de obter o melhor cuidado.

Eu faço geralmente relatórios mensais para os familiares responsáveis a respeito disso. (G.I.4.12)

Então é um profissional importante nesse cuidado, atuando como um eixo de todas as informações, que vai direcionar os cuidados e conseguir entender melhor o caso. (G.II.9.26)

\subsection{Liderar a equipe}

Duas, das gerontólogas entrevistadas, citaram em seus depoimentos o papel do gerontólogo como líder da equipe de trabalho, motivando as profissionais, exaltando suas capacidades, gerenciando conflitos e, sobretudo, organizando o atendimento de modo geral.

Eu sempre exalto o que elas já aprenderam, que eu acredito que elas são competentes para aquilo, que eu só estou lembrando alguns pontos. (G.V.8.32)

...eu sei que eu sou líder, então eu tenho que ser firme. (G.I.8.23)

Segundo Melo, Lima-Silva e Cachione (2015), o gerontólogo é capaz de reconhecer as dimensões físicas, emocionais e sociofamiliares que integram a vida dos idosos, com foco na gestão do cuidado prestado, pois este profissional possui competências pessoais, técnicas (conhecimento, gestão administrativa, microgestão, mesogestão e macrogestão) e gerenciais (liderança, tomada de decisão, gerenciamento de conflitos, visão sistêmica, planejamento e orientação para resultados), que lhe permite desenvolver e implementar seu plano de ação. 


\subsection{Unir equipe multiprofissional, familiares e cuidadores}

Como já mencionado em outras categorias apresentadas, o gerontólogo é o profissional responsável por dialogar com todos os atores envolvidos no cuidado ao idoso. Assim sendo, verifica-se no discurso, que além de obter as informações, ele alinhará todos os dados para torná-los comuns a todos, de forma que o cuidado seja de fato personalizado e individual.

...então nossa rotina gira em torno da família, do idoso e do cuidador. (G.II.4.9)

...então o gerontólogo no cuidado domiciliar é um gestor muito importante, ele é o eixo que vai alinhar os cuidados com a família o cuidador e o idoso. (G.II.5.21)

Para Duarte e Lebrão (2006), os gerentes do cuidado gerontológico devem atuar como ponte entre as demandas identificadas e os recursos existentes e disponíveis, o que em termos assistenciais, facilita o caminho para os melhores resultados e contribui, com a utilização dos serviços sociais e de saúde, para as experiências dos idosos e seus familiares.

Segundo o estudo de Pereira, Malta e Pimentel (2012) que foi realizado em Portugal, as instituições empregadoras de gerontólogos reconhecem a habilidade deste profissional em integrar e dinamizar equipes técnicas, uma vez que o gerontólogo possui uma polivalência de conhecimentos e intervenções, tanto da área da saúde como da área social (Melo; Lima-Silva; Cachione, 2015).

\subsection{Gerenciar a escala da equipe de cuidadores}

Verifica-se, através dos depoimentos das gerontólogas, que o trabalho executado vai além daqueles relativos à assistência. Os gerontólogos também assumem responsabilidades administrativas como, por exemplo, a gestão da escala de trabalho dos cuidadores.

... a escala, por exemplo, estar de olho na escala e tentar suprir as necessidades do cuidador, desse profissional, faz com que ele tenha, que ele esteja feliz e satisfeito de estar trabalhando na empresa. E isso automaticamente impacta no cuidado do idoso. (G.II.4.12)

Tentar controlar para que não tenha muitos furos de escala e a gente possa manter a qualidade nisso. (G.IV.5.10) 
Cornélio (2010) aponta em seu estudo a dificuldade em relação aos recursos humanos e como a falta de funcionários deixa o cuidador com tempo escasso para desenvolver suas atividades, acarretando situações delicadas como, por exemplo, quando este profissional fica sozinho no período noturno, em situações emergenciais e/ou aquelas que exigem de sua força física, devido ao excesso de peso do idoso. Situações como estas prejudicam o andamento do cuidado e, de acordo com os discursos obtidos, o gerontólogo tem o papel de gerenciar problemas relacionados, também, aos recursos humanos.

\subsection{Identificar e atender as necessidades do paciente e sua família}

Considerando os depoimentos obtidos, o gerontólogo é responsável por auxiliar o idoso e sua família a identificar as necessidades de cuidado e, a partir disso, orientar a equipe para que tais necessidades sejam supridas. Além disso, o gerontólogo alinhará as expectativas dos cuidadores com as da família/idoso.

...ele conhecendo esse idoso ele vai conseguir entender e identificar quando tiver alguma coisa errada com esse idoso, identificar o que esse idoso precisa, o que ele quer, então a partir disso, você vai conseguir orientar o cuidador, né? (G.II.5.17)

...e alinhando as expectativas do que este cuidador pode realizar, o que são atribuições esperadas por este cuidador dentro da casa. (G.V.6.26)

O gerontólogo realizará a avaliação gerontológica e elaborará planos de atenção integral à pessoa idosa, de forma que sejam consideradas suas necessidades biopsicossociais. Brêtas e Yoshitome (2005) apontam que as visitas realizadas no domicílio não devem ser exclusivas aos idosos, pois também é importante entender a necessidade da família, oferecendo-lhe apoio, suporte e orientação.

\subsection{Mediar e gerenciar o cuidado}

Segundo a fala de algumas participantes, o gerontólogo também desenvolve o papel de mediar e gerenciar todas as situações que envolvem o cuidado, principalmente àquelas que geram conflitos. 
...empatia, tentar entender o outro e mediação, sempre mediando conflitos o tempo inteiro. $O$ gerontólogo faz muito esse papel no cuidado domiciliar, de gerir esses conflitos entre a família, o idoso e o cuidador. (G.II.11.37)

...eu vejo o gerontólogo como um mediador, então um mediador entre os cuidadores, um mediador entre as pessoas. (G.V.1.1)

O termo sobrecarga (burden) é utilizado para descrever os efeitos negativos da tarefa de cuidar que afetam o cuidador (Figuereido\& Sousa, 2008) e como esses efeitos podem ser caracterizados como um estressor, os quais ocorrem nas situações em que as famílias são forçadas a ajustar ou a desenvolver novas estratégias de lidar com a pessoa doente e seus sintomas (Gratão, 2010). O conceito também inclui a compreensão de problemas físicos, psicológicos ou emocionais, sociais e financeiros, vivenciados por famílias cuidadoras (Zarit et al., 1980).

O processo de cuidar é complexo, envolvendo dificuldades na prática diária para a maioria dos cuidadores durante o desempenho de suas funções, por esse motivo, alguns estudos apontam as principais dificuldades enfrentadas pelos cuidadores formais. Cornélio (2010), além de descrever em seu estudo a dificuldade em relação aos recursos humanos e a falta de funcionários, destaca também as dificuldades relacionadas à habilidade técnica (troca de fralda, medicação ou locomoção do idoso cadeirante) e/ou psicológica (lidar com o comportamento do idoso com resistência ou agressividade devido aos transtornos mentais e doenças como Alzheimer, bem como compreender idoso não contactuante).

Estudo realizado por Areosa et al. (2014), buscou identificar as principais queixas atribuídas ao cuidado do idoso e para isso os autores entrevistaram cuidadoras formais e informais. Verificou-se uma diferença importante na fala das cuidadoras formais em comparação às informais, sendo que estas últimas, as informais, apresentaram como dificuldade a de dedicar a vida em função de outra pessoa, durante o dia e inclusive à noite. Já as cuidadoras formais mostraram-se mais compreensíveis com a situação do idoso. Por mais que duas delas apresentaram certas queixas quanto aos esforços físicos e, também, ao estresse provocado pela atividade, pode-se perceber que seus discursos diferem do cuidador familiar. $\mathrm{O}$ fato de o cuidado ser considerado um trabalho, e consequentemente, se converter em uma fonte de renda para esta cuidadora, diverge-se também da cuidadora familiar que cuida por obrigação ou sofre pela situação de dependência do idoso. 
Assim, verificam-se na literatura algumas dificuldades apontadas por cuidadores formais e cuidadores familiares. Falcão e Bucher-Maluschke (2010) apontam que o mediador é alguém capaz de ajudar as partes para definir o que é viável diante de uma situação de conflito. O gerontólogo, de acordo com os depoimentos obtidos, auxilia aos envolvidos, no processo do cuidar, a lidar com estas dificuldades, mediando possíveis conflitos que possam surgir em decorrência destas.

\subsection{Supervisionar o cuidado}

Para uma das gerontólogas entrevistadas, o trabalho no domicílio envolve a supervisão dos cuidados/cuidadores. O termo surgiu nos discursos para definir ações nas quais a gerontóloga coloca-se no papel de vigilância e/ou fiscalização.

No cuidado domiciliar que eu exerço hoje, eu sou principalmente uma supervisora dos cuidados realizados pelos cuidadores. (G.V.5.20)

Então o gerontólogo é a pessoa que olha para todo aquele ambiente, que supervisiona. (G.V.1.7)

\section{$\underline{\text { 5.2.1.4.11 Capacitar e orientar os cuidadores de idosos }}$}

A maioria das gerontólogas entrevistadas tem como motivação de trabalho a oportunidade de capacitar e orientar os cuidadores, no âmbito geral, por meio de treinamentos referentes à velhice e ao envelhecimento. E, no âmbito particular, referente às questões relativas a cada paciente.

...parte de treinamento, eu participo muito da parte de capacitação dos cuidadores e treinamento. (G.III.5.7)

Eu acho que eu consegui, de alguma forma, primeiro capacitar alguns cuidadores para essa parte de atividades, porque toda vez que eu vou fazer uma visita de supervisão no domicílio eu proponho algumas atividades, deixo outras e peço para eles entregarem depois. (G.IV.9.12)

O Curso de Cuidador de Idosos é livre, ou seja, qualquer pessoa e/ou instituição pode oferecê-lo. Até que a ocupação de cuidador seja regulamentada como profissão, não existe obrigatoriedade de padronização nem de fiscalização para os cursos oferecidos. Atualmente, 
existe uma grande variedade de cursos, que diferem entre si quanto a: instituição responsável, carga horária, duração, conteúdo, didática, metodologia, materiais didáticos, estágios e valores. A CBO sugere que os Cursos de Cuidadores tenham entre 60 e 180 horas e exige que este cuidador tenha o ensino fundamental completo (MTE, 2016).

As gerontólogas entrevistadas referem que atuam em cursos de cuidadores, ministrando aulas e, além disso, realizam a orientação continuada do profissional, diariamente, através de visitas presenciais e contato telefonico.

...as cuidadoras são orientadas o tempo inteiro (G.V.9.38)

...no dia a dia se eu pego algum erro que eles estão cometendo em relação à classificação de uma doença ou de algum procedimento que não está correto, eu vou no dia a dia corrigindo. (G.V.5.21)

\subsection{Dar suporte integral e eficaz aos cuidadores}

Para algumas cuidadoras o gerontólogo precisa fornecer um suporte também para a equipe de cuidadores, colocando-se à disposição sempre que necessário. Observa-se no discurso que os gerontólogos ficam integralmente acessíveis para qualquer intercorrência que houver no atendimento.

...você tem que estar com seu telefone ligado o tempo todo, então meu celular está sempre ligado. (G.I.4.7)

...ter uma atenção maior e específica com o cuidador, no caso o cuidador profissional, que a gente contrata para estar na casa do idoso. Também é uma demanda do gerontólogo. (G.II.4.8)

O suporte gerontológico integral para os cuidadores formais é de extrema importância para garantir a qualidade do trabalho executado e a qualidade de vida deste profissional. Ferreira, Alexandre e Lemos (2011), em seu estudo sobre fatores associados à qualidade de vida de cuidadores de idosos em assistência domiciliária aponta que cuidadores formais apresentam pior desempenho em relação ao estado geral de saúde, quando comparados aos cuidadores informais, pois aponta que cuidadores contratados podem não estar preparados para enfrentar as dificuldades do cuidar, tornando, então, o problema do cuidado mais grave do que 
aparenta. $\mathrm{O}$ autor nos apresenta que o cuidador formal também sofre sobrecarga física e mental com implicações negativas à sua saúde.

\subsection{Adaptar o ambiente para a seguranca do idoso}

Uma das participantes apontou a preocupação do gerontólogo com o ambiente que o idoso convive, conforme podemos verificar na frase abaixo.

...verifico como está a infraestrutura do ambiente, então tem casa que tem câmera eu vou checar pra ver se está tudo funcionando, se está tudo em ordem. (G.I.5.15)

Um aspecto que ganha relevância no período de envelhecimento refere-se à questão do

local de moradia. É na velhice que o local de moradia atua como uma dimensão que intervém e que pode atender, ou não, às novas necessidades emergentes (Tomasini, 2005). Para o idoso, o ambiente, nos seus aspectos físico e social, torna-se um ponto decisivo para o desenvolvimento e a manutenção de um estilo de vida adequado, que promova qualidade de vida e que preserve a capacidade funcional, independência e autonomia. Cabe neste contexto ao gerontólogo, a tarefa de verificar se a moradia está contribuindo para o bem-estar do idoso de forma eficiente e segura.

\subsection{Avaliar o idoso}

De acordo com o discurso de algumas participantes, a gestão realizada pelo gerontólogo é posterior à avaliação inicial, que tem como objetivo levantar as demandas do idoso, entender o contexto social e familiar, além de levantar o histórico de vida do indivíduo.

...eu faço primeiramente uma avaliação bem longa, bem extensa, pra saber tudo e vai desde questões, por exemplo, essa paciente, ela quando criança a mãe faleceu, então ela foi entregue para os tios, então ela nunca teve carinho de família, então essa informação pra mim é relevante pra tentar entender que ela não dá carinho para as pessoas, para os netos. (G.I.6.19)

E quando aparece algum novo cliente eu que realizo as avaliações (G.V.4.18)

Os componentes básicos que envolvem o cuidado gerontológico são: avaliação, planejamento do cuidado, coordenação e implementação de soluções, monitoramento do plano de cuidados e avaliação dos resultados. O processo de gerenciamento não se inicia sem que haja 
uma avaliação inicial, a qual levantará as demandas e os problemas relacionados às áreas psicosocial, econômica, legal e de saúde experenciadas pelo idoso e família. A partir da avaliação o planejamento do cuidado será desenvolvido e, por conseguinte, as demais etapas descritas (Duarte; Lebrão, 2006).

\subsection{Ajudar a melhorar a saúde do idoso}

Verifica-se no discurso de algumas participantes, que a atuação do gerontólogo como gestor do cuidado traz uma melhora significativa à saúde do paciente idoso. Não foi mencionado método de avaliação a qual pudesse ser constatada essa melhoria, somente a visão da gerontóloga e o parecer dos familiares em relação à evolução do paciente.

...você ver que essa pessoa, ela pode melhorar na sua mão, sabe? Nem que seja um pouquinho, e você está preservando os valores dela. (G.I.12.27)

A minha mediação ela tem sido satisfatória, porque os resultados tem sido bons, as famílias têm dado feedbacks positivos em relação a todo o trabalho que tem sido feito nas casas, com os pacientes que estão melhorando aos poucos. (G.V.11.50)

A atuação do gerontólogo possui como foco a gestão da atenção ao envelhecimento e à velhice, essencialmente a partir da promoção do envelhecimento saudável, ativo e significativo (Melo; Lima-Silva; Cachione, 2015). Partindo deste ponto, podemos estabelecer que os procedimentos adotados pelo profissional no decorrer do atendimento vão convergir com a melhora do idoso em todos os âmbitos, inclusive da saúde. Vale ressaltar, que nem sempre essa evolução ocorre, devido aos diversos fatores associados ao processo da doença, organismo e/ou enfretamento de cada paciente. Todavia cabe ao gerontólogo, juntamente com a equipe interprofissional, desenvolver estratégias que favoreçam a melhora sempre que possível.

\subsection{Ter contato próximo com o idoso}

Esta categoria surgiu nos motivos porque e motivos para, ou seja, para as gerontólogas entrevistadas, o fato de terem um contato próximo com o idoso, foi o motivo principal que as levaram a trabalhar no cuidado domiciliar - motivo porque - e que também é o motivo que as fazem continuar atuando neste contexto, uma vez que a categoria se constitui como uma ação do momento e uma expectativa - motivo para. 
A relação que é gratificante demais, com o idoso principalmente, é o que eu considero uma das principais vantagens na atuação do cuidado domiciliar. (G.III.12.10)

...contato próximo com o paciente, que em alguns serviços a gente não tem esse contato tão direto. (G.V.12.52)

\subsection{Incentivar a autonomia e a independência do idoso}

Esta categoria expõe a motivação de algumas gerontólogas em incentivar a autonomia e independência do idoso no decorrer o atendimento.

E sempre buscando que eles incentivem este idoso a obter uma maior autonomia, uma maior independência, manter estas atividades preservadas, né? Nunca tirar isso deles, sempre incentivá-los. (G.V.5.24)

...eu evito falar sobre o idoso como se ele não estivesse ali, eu gosto que ele participe deste processo. (G.V.7.29)

Adoecer, ficar dependente e perder a autonomia, são situações que causam desequilíbrio individual e coletivo, principalmente no ambiente domiciliar (Pavarini; Neri, 2005). Preservar a autonomia e manter a independência no maior grau possível é um dos objetivos do cuidado ao idoso (Pavarini, 2005).

Os gerontólogos, neste cenário, por atuarem diretamente no cuidado ao idoso, poderão contribuir para a manutenção da autonomia e independência do idoso através da promoção ao desenvolvimento e na adaptação de funções, visando à autonomia e independência do paciente e, principalmente, através de orientações para os familiares, cuidadores e profissionais da equipe interprofissional.

\subsection{Zelar pela segurança do idoso}

Uma das gerontólogas entrevistadas apresentou, em seu depoimento, a questão sobre violência contra o idoso no domicílio. Para ela, o gerontólogo deve zelar pela segurança do idoso durante o atendimento. Em seu discurso, a participante retrata uma situação vivenciada e explica, através de seu ponto de vista, como o gerontólogo pode atuar para minimizar o problema. 
A gente teve até um recente caso que a gente suspeitou de agressão por parte da família, e a gente foi pra cima, a gente conversou com o filho, a gente conversou com o cuidador, a gente começou a cercar esta família, porque se realmente, se a gente souber que algo aconteceu contra este idoso, eles estão cientes que a gente pode romper contrato, que a gente pode denunciar e isso a gente fala já no começo, na primeira avaliação, a gente já coloca para a família que se algo acontecer que seja fora do que está previsto no estatuto do idoso, ou que tenha algum tipo de agressão moral ou física a este paciente, que a gente vai se posicionar.(G.V.9.34)

As cuidadoras são orientadas o tempo inteiro se elas virem algum tipo de marca, se elas virem que o estado clínico do paciente, se elas virem que algo não está normal, a gente todos os dias, a gente tem um relato de plantão pelo WhatsApp e elas nos falam o que está acontecendo, as preocupações delas em relação a estes pacientes. (G.V.9.39/40)

A violência é um tema cada vez mais frequente quando tratamos do idoso, todavia, abordar as questões relacionadas à violência praticada contra o idoso, ainda é algo bastante delicado e complexo (Berzins; Watanabe, 2010). Isso porque entramos numa área de discussão que aborda traumas de natureza psicológica, emocional, moral e física.

Apesar das dificuldades em tratar à temática e penetrar no silêncio, seja das instituições, das famílias e/ou dos próprios idosos, alguns avanços estão acontecendo já que desde a década de 1990, a violência contra pessoas idosas começou a receber destaque e atenção (Berzins; Watanabe, 2010).

Esse assunto merece especial atenção dos cuidadores de idosos que possuem a possibilidade de identificar, de maneira mais rápida, a violência que o idoso tem sofrido, devido sua proximidade e atuação direta (Newton et al., 2015). Neste cenário doméstico é responsabilidade do gerontólogo fornecer suporte e orientação aos cuidadores em relação à temática e, juntamente com o cuidador, manter a atenção aos sinais demonstrados pelo idoso. No âmbito acadêmico, o gerontólogo deverá contribuir para com as pesquisas, levantando o maior número de dados para que políticas públicas sejam mais bem elaboradas e assim, oferecer respostas às necessidades dessa parcela da população.

\subsection{Dar orientacão e suporte aos familiares}

Além de orientar os cuidadores formais alguns gerontólogos também realizam a orientação dos familiares. Neste caso, a orientação está relacionada ao suporte emocional, mais do que ao suporte técnico. Conforme podemos observar nas falas abaixo. 
...eu converso com o familiar, eu dou todo respaldo pro familiar, qualquer dúvida o familiar me liga, então eu fico à disposição pra que ele ligue e pergunte. (G.I.5.14)

E também, para uma assistência da família mesmo, né? De tirar algumas dúvidas, ajudar, orientar algumas redes de suporte social, ou rede de suporte médica mesmo. (G.IV.9.13)

Os cuidadores informais/ familiares, na maioria das vezes, não possuem conhecimento, suporte, informação e preparação adequadas e /ou suficientes para realizar a tarefa de cuidar (Couto \& Castro, 2013). Mesmo com a contratação de profissionais para executar o cuidado, muitos familiares ainda permanecem envolvidos, principalmente emocionalmente ligados ao cuidado.

Segundo Hudson (2012), existem muitas razões pelas quais os cuidadores familiares devem receber apoio psicossocial, dentre elas: os cuidadores geralmente são propensos à morbidade física e psicológica; são responsáveis para inúmeras tarefas, como o gerenciamento de doenças; são financeiramente desfavorecidos; tornam-se socialmente isolados; apresentam insatisfações com a vida; experimentam sofrimento psicológico em níveis altos; muitas vezes não estão cientes de que há suporte disponível; têm necessidades iguais e / ou maiores que as necessidades dos pacientes; têm exposição prévia à morte e ao processo de morrer.

Observamos, através dos depoimentos, que o gerontólogo participa ativamente deste processo de aceitação e compreensão da situação instalada, fornecendo suporte psicossocial e contribuindo para o desenvolvimento de um envelhecimento saudável, apoiando o cuidado e encorajando a participação ativa da família e do idoso nesse processo (Lima, 2009).

\subsection{Incentivar a família para um melhor cuidado}

Segundo uma das cuidadoras entrevistadas, os familiares tornam-se mais cuidadosos e atenciosos com o idoso quando existe a gestão gerontológica, nesse sentido, a gerontóloga ressalta a importância de incentivar a família para um melhor cuidado.

...eu vejo principalmente pelo que eu falei desta mediação que o gerontólogo faz, a família eu vejo que ela tem mais cuidado da forma que ela lida com o idoso. (G.V.9.35)

Então eu sinto que a família fica mais cuidadosa, porque ela sabe que não é alguém que está ali só para fazer o que ela quer. (G.V.9.36) 
Segundo Angelo (2005), pensar na família é um desafio para os profissionais de saúde. Este exercício vai além de orientar e esperar a colaboração da família no desempenho de ações de cuidado em prol do familiar doente, já que pensar na família é tomá-la como perspectiva.

No contexto domiciliar tomar a família como perspectiva significa, sobretudo, considerar o seu grande potencial como aliada à manutenção e restauração da saúde do idoso. O profissional gerontólogo, a partir da análise e avaliação familiar, deverá incentivar a família a assumir um papel ativo na vivência do cuidado da saúde de um de seus membros, de forma que não assuma um papel de depositário, passivo, de ordens dos profissionais da saúde (Angelo, 2015).

\subsection{Divulgar a profissão de gerontólogo}

De acordo com os depoimentos abaixo para alguns gerontólogos, o motivo para atuar no cuidado domiciliar é a oportunidade de divulgar a profissão.

Uma vantagem de trabalhar como gerontólogo no domicílio é a divulgação da profissão, porque eu acho que acaba acontecendo muito "boca a boca" de uma família para a outra, no sentido de até de me pedirem visitas. (G.IV.12.17)

...os cuidadores ...É um novo nicho que a gerontologia está explorando, é um nicho que tem muito a crescer, então eu acho que estar no domicílio e estar com esses profissionais divulga e engrandece a nossa profissão. (G.V.12.54)

Segundo Melo, Lima-Silva e Cachione (2015) a baixa procura pela graduação em Gerontologia é uma realidade no Brasil, principalmente quando comparada a outros cursos da área da saúde. Além disso, possíveis instituições empregadoras não compreendem a função do Gerontólogo e o seu reconhecimento em detrimento de outros profissionais com especialização na área da Gerontologia ainda é pequeno.

Considerando o cenário nacional, é notável ter profissionais atuando como gerontólogas motivadas a divulgar a própria profissão para a população em geral e, principalmente, para os profissionais e empregadores que estão atuando no campo da gerontologia.

\subsection{Ser valorizado como gerontólogo}


Para algumas gerontólogas o motivo para atuar no cuidado domiciliar é o de sentir-se valorizada no ambiente de trabalho.

Atuar como gerontólogo no atendimento domiciliar é muito gratificante, porque você tem uma devolutiva diretamente com a família, com o cuidador, com o próprio idoso. (G.II.1.1)

Schütz define ação social como sendo uma conduta dirigida para a realização de um determinado fim, e esta ação - motivo para - só pode ser interpretada pela subjetividade de quem a vivência, pois somente a própria pessoa pode definir seu próprio projeto e seu desempenho social (Merighi et al., 2006).

O motivo para é um contexto de significado que é construído ou se constrói sobre o contexto de experiências disponíveis no momento da projeção e que estão voltadas para o futuro, ou seja, relacionados às expectativas e projetos do ator da ação (Schütz, 1972; 1974).

Algumas gerontólogas, apesar de não sentirem-se valorizadas no ambiente de trabalho, relataram a expectativa de serem reconhecidas dentro deste contexto, ou seja, para elas o motivo para atuar no cuidado domiciliar é a expectativa de ser valorizada como gerontóloga.

...eu espero que cresça muito essa atuação do gerontólogo nesse atendimento, mas de uma forma que seja reconhecida, de uma forma que não seja "ah! É uma mão de obra barata”, aí você vai lá e coloca o gerontólogo porque é mais barato, não! Tem que ser reconhecido. (G.III.14.15)

\subsection{Aprender com as situacões e ter resolutividade}

Para algumas gerontólogas participantes, o trabalho é a oportunidade de aprender com os desafios e situações cotidianas. De acordo com os discursos, podemos observar situações que as obrigam a ter resolutividade e a serem ágeis na tomada de decisões.

...que você tem que ter muita inteligência emocional pra lidar, muita, porque são várias situações desafiadoras, que você perde o chão, mas depois você respira fundo e pensa "como é que a gente vai resolver?" (G.I.13.31)

...eu acho que é desafiador, porque como eu falei anteriormente, você tem que ser ágil, você tem que ser resolutiva e isso você só desenvolve na prática, e acho que em nenhum outro lugar eu teria desenvolvido essas habilidades se não fosse na assistência domiciliar. (G.III.12.11) 


\subsection{Ter mais flexibilidade e autonomia no trabalho}

Maior flexibilidade de horário e mais autonomia na tomada de decisões caracterizaram motivos para as gerontólogas decidirem trabalhar no cuidado domiciliar. Segundo as entrevistadas, trabalhar nesta área é muito dinâmico, porque muitas vezes o gerontólogo tem que decidir e resolver uma situação de maneira imediata, o que a partir de suas perspectivas, foi apontado como fator positivo do trabalho.

...nessa empresa, eu tenho autonomia de resolver as coisas, de decidir as coisas, a gente não depende de um médico ou de um enfermeiro para decidir as coisas, a gente chega e fala "olha eu resolvi por esse cuidado e pronto, a gente tem que seguir nessa linha e pronto". (G.III.12.12)

você também consegue ter uma flexibilidade maior de horário, não é uma coisa que você tem que bater ponto porque é uma coisa muito flexível, dinâmica o tempo todo, então tem hora que você vai pra um lugar ou pra outro, tem várias casas, vários idosos, então existe essa flexibilidade de tempo, né? (G.II.12.40)

\subsection{Colocar os conhecimentos teóricos em prática}

Esta categoria surge nos motivos porque e motivos para. Uma das gerontólogas entrevistadas teve como motivação de trabalhar na área a oportunidade de colocar os conhecimentos teóricos em prática. E continua na gestão do cuidado pelo mesmo motivo.

...a vivência de trabalhar nos cuidados no domicílio, na verdade, é uma oportunidade de colocar tudo o que eu aprendi na teoria na prática... (G.V.2.11)

...é uma área que eu estudo, que eu gosto e me interesso, é uma área que eu já pesquisei muito, e agora eu tenho a oportunidade de trabalhar como gerontóloga naquilo que eu via nos artigos e nos trabalhos que eu fiz. (G.V.2.12)

Dessa forma, motivo para é a orientação para a ação futura que se manifesta no momento da entrevista e o motivo porque está relacionado às vivências passadas, com os conhecimentos disponíveis (Merighi, 2006).

Para melhor entendermos o motivo porque podemos pensar na figura da graduanda em Gerontologia, que está planejando trabalhar no cuidado domiciliar a fim de colocar seu conhecimento adquirido em prática, já para motivo para, podemos pensar na profissional já 
graduada que, atualmente, atua no cuidado domiciliar, com isso tem a oportunidade de colocar seu conhecimento em prática e, ainda, projetar-se para continuar vivenciando esta ação.

O esquema a seguir ilustra as categorias de motivos porque e motivos para atuar como gerontólogo no cuidado domiciliar, considerando os depoimentos dos gerontólogos e cuidadores formais de idosos. 
Quadro 5 - Categorias Motivos Para e Motivos Porque dos Cuidadores e Gerontólogos

\begin{tabular}{|c|c|}
\hline CUIDADORES & GERONTÓLOGOS \\
\hline $\begin{array}{l}\text { MOTIVOS PORQUE OS CUIDADORES } \\
\text { TRABALHAM COM O GERONTÓLOGO }\end{array}$ & $\begin{array}{l}\text { MOTIVOS PORQUE OS GERONTÓLOGOS } \\
\text { TRABALHAM NO CUIDADO DOMICILIAR }\end{array}$ \\
\hline Por indicação & Acreditar no modelo de atendimento domiciliar \\
\hline Poder administrar melhor o cotidiano & Ter a demanda de clientes e cuidadores \\
\hline Ter um profissional realizando a gestão do atendimento & Acreditar no trabalho do gerontólogo \\
\hline Evitar a insegurança e solidão de ser cuidador & Trabalhar diretamente com o idoso no domicílio \\
\hline Ter supervisão das atribuições do cuidador & Facilidade em conseguir o emprego \\
\hline \multirow[t]{2}{*}{ Não precisar tratar diretamente com a família } & Experiência acadêmica \\
\hline & Indicação profissional \\
\hline $\begin{array}{l}\text { MOTIVOS PARA OS CUIDADORES } \\
\text { TRABALHAREM COM O GERONTÓLOGO }\end{array}$ & $\begin{array}{l}\text { MOTIVOS PARA OS GERONTÓLOGOS } \\
\text { TRABALHAREM NO CUIDADO DOMICILIAR }\end{array}$ \\
\hline Gerenciar os conflitos familiares & Realizar a gestão gerontológica do atendimento \\
\hline Dar segurança para o paciente e cuidador & Capacitar e orientar aos cuidadores de idosos \\
\hline Orientar a equipe de cuidadores & Dar suporte integral e eficaz aos cuidadores \\
\hline Zelar pela saúde do idoso & Acompanhar presencialmente o atendimento realizado \\
\hline Adaptar o ambiente para a segurança do idoso & Administrar o cuidado com o idoso \\
\hline $\begin{array}{l}\text { Auxiliar o cuidador no processo de adaptação com o } \\
\text { paciente }\end{array}$ & Administrar as informações sobre o idoso \\
\hline Administrar as informações sobre o idoso & Dar orientação e suporte aos familiares \\
\hline Identificar e atender as necessidades do paciente & Adaptar o ambiente para a segurança do idoso \\
\hline Orientar o paciente e seus familiares & Avaliar o idoso \\
\hline Dar suporte integral e eficaz aos cuidadores & Liderar a equipe \\
\hline Unir equipe multiprofissional, familiares e cuidadores & Ajudar a melhorar a saúde do idoso \\
\hline Realizar trabalhos administrativos & Divulgar a profissão de gerontólogo \\
\hline Acompanhar presencialmente o atendimento realizado & Ser valorizado como gerontólogo \\
\hline Acolher a equipe de cuidadores, familiares e paciente & Unir equipe multiprofissional, familiares e cuidadores \\
\hline Não precisar tratar diretamente com a família & Gerenciar a escala da equipe de cuidadores \\
\hline \multirow[t]{10}{*}{ Apoiar no processo de luto } & Identificar e atender as necessidades do paciente e sua família \\
\hline & Aprender com as situações e ter resolutividade \\
\hline & Ter mais flexibilidade e autonomia no trabalho \\
\hline & Ter contato próximo com o idoso \\
\hline & Colocar os conhecimentos teóricos em prática \\
\hline & Mediar e gerenciar o cuidado \\
\hline & Supervisionar o cuidado \\
\hline & Incentivar a autonomia e a independência do idoso \\
\hline & Zelar pela segurança do idoso \\
\hline & Incentivar a família para um melhor cuidado \\
\hline
\end{tabular}

Fonte: Jullyanne Marques Sousa Teixeira, 2017

\subsubsection{Construção do tipo vivido}

Com base na análise aprofundada dos motivos para e motivos porque deste trabalho, foi possível analisar o significado do gerontólogo como gestor do cuidado formal domiciliar na perspectiva dos cuidadores formais e dos próprios gerontólogos.

A fenomenologia social tem como objeto de conhecimento a ação social em suas esferas de significado. Neste sentido, trata-se de uma tentativa de descrever os processos de 
estabelecimento e interpretação de significado tais como são realizados pelas pessoas que vivem no mundo social (Boava; Macedo, 2012).

Cada pessoa, durante toda a sua existência, interpreta o mundo na perspectiva de seus próprios interesses, motivos, desejos, compromissos ideológicos e/ou religiosos. Assim, apesar da realidade, oriunda do senso do comum, ser dada de forma cultural como universal, o modo como essas formas expressam-se na vida individual depende da totalidade da experiência que o sujeito constrói no curso de sua existência concreta (Jesus et al., 2013).

A biografia do sujeito e o acervo de seus conhecimentos disponíveis e acessíveis condicionam a projeção da ação que é, essencialmente, subjetiva e individual. Para concretizar algo subjetivo, faz-se necessário construir um esquema conceitual, o qual permite agrupar as informações acerca desse mundo - a tipificação (Jesus et al., 2013).

A tipificação é um aspecto comum dos seres humanos. Neste processo, as tipificações não contemplam o que há de diferente e particular nos elementos da vida intersubjetiva, mas os fatores específicos e comuns que permitem atribuir identidade coletiva aos fenômenos (Boava; Macedo, 2012).

A tipificação compreensiva de Schütz se faz pela organização teórica das categorias advindas dos motivos para e motivos porque dos sujeitos inseridos no mundo social. A partir deste processo, chega-se ao tipo vivido de um dado grupo (Schütz, 1972; 1974).

O tipo vivido construído retrata o que há de comum nas categorias, permitindo uma analise objetiva sobre o significado do fenômeno. Considerando o estudo realizado, notamos que apesar de gerontólogos e cuidadores vivenciarem experiências diferentes e particulares, é possível, através da análise e organização das categorias motivos para e motivos porque, construir o tipo vivido do "gerontólogo gestor do cuidado formal domiciliar".

Assim, a compreensão que parte da motivação existencial tem, ao mesmo tempo, um significado que é subjetivo - porque foi vivenciado pelos sujeitos - e objetivo - porque se refere a uma situação concreta, a qual se mostra significativa e relevante para aqueles que vivenciam o fenômeno investigado (Jesus et al., 2013).

Trata-se de uma representação invariante da ação do grupo que a torna homogênea, abstendo-se das características individuais. Por ser construída de maneira objetiva, pode ser expressa mediante a uma linguagem significativa, sendo reconhecida e compreendida por aqueles que vivenciam uma situação semelhante (Jesus et al., 2013).

Neste sentido, os demais gerontólogos que vivenciam a mesma situação, de gestor do cuidado formal domiciliar, podem compreender os significados desta ação através do tipo vivido construído neste estudo. 
Sob o olhar da fenomenologia de Alfred Schütz e das categorias oriundas dos motivos para e motivos porque apresentamos a elaboração dos tipos vividos dos cuidadores e gerontólogos.

\subsubsection{Tipo vivido dos Cuidadores}

As categorias concretas do vivido a partir da ação subjetiva permitiram descrever o tipo vivido dos cuidadores que estavam sob a gestão de gerontólogos.

O tipo vivido do cuidador constitui-se de gerontólogos que:

- Orientam a equipe de cuidadores;

- Zelam pelo cuidado da saúde do idoso;

- Auxiliam o cuidador no processo de adaptação com o paciente;

- Dão suporte integral e eficaz aos cuidadores.

\subsubsection{Tipo vivido dos Gerontólogos}

As categorias concretas do vivido a partir da ação subjetiva permitiram descrever o tipo vivido de gerontólogos gestores do cuidado formal domiciliar na perspectiva dos próprios gerontólogos.

O tipo vivido constitui-se de gerontólogos que:

- Realizam a gestão gerontológica do atendimento;

- Capacitam e orientam aos cuidadores de idosos;

- Dão suporte integral e eficaz aos cuidadores;

- Acompanham presencialmente o atendimento realizado;

- Administram as informações sobre o idoso;

- Dão orientação e suporte aos familiares;

- Ajudam a melhorar a saúde do idoso;

- Unem equipe multiprofissional, familiares e cuidadores;

- Identificam e atendem as necessidades do paciente e da sua família;

- Aprendem com as situações e têm resolutividade;

- Têm contato próximo com o idoso;

- Sentem-se valorizados como gerontólogos. 


\subsubsection{Apresentação das dificuldades enfrentadas por cuidadores e gerontólogos.}

Uma das perguntas norteadoras realizadas aos cuidadores foi "No geral, você tem alguma dificuldade de lidar com o atendimento domiciliar sob a supervisão de um gerontólogo? Por quê?". Das 15 cuidadoras entrevistadas, somente uma referiu ter dificuldade, sendo essa dificuldade descrita pelo excesso de visitas gerontológicas. Segundo a cuidadora, o gerontólogo realiza as orientações iniciais de forma eficiente diminuindo a necessidade de muitas visitas presenciais no decorrer do atendimento, para ela, o ideal seria de uma a duas visitas no mês.

Já para os gerontólogos a pergunta foi realizada da seguinte forma: "No geral, existe alguma dificuldade em exercer a profissão de gerontólogo no ambiente domiciliar? Qual ou quais?". Para melhor compreensão, considerando a quantidade das dificuldades as quais foram apontadas, agrupamos em quatro grupos e as apresentaremos no esquema abaixo.

Figura V - Dificuldades enfrentadas pelos gerontólogos no ambiente de trabalho

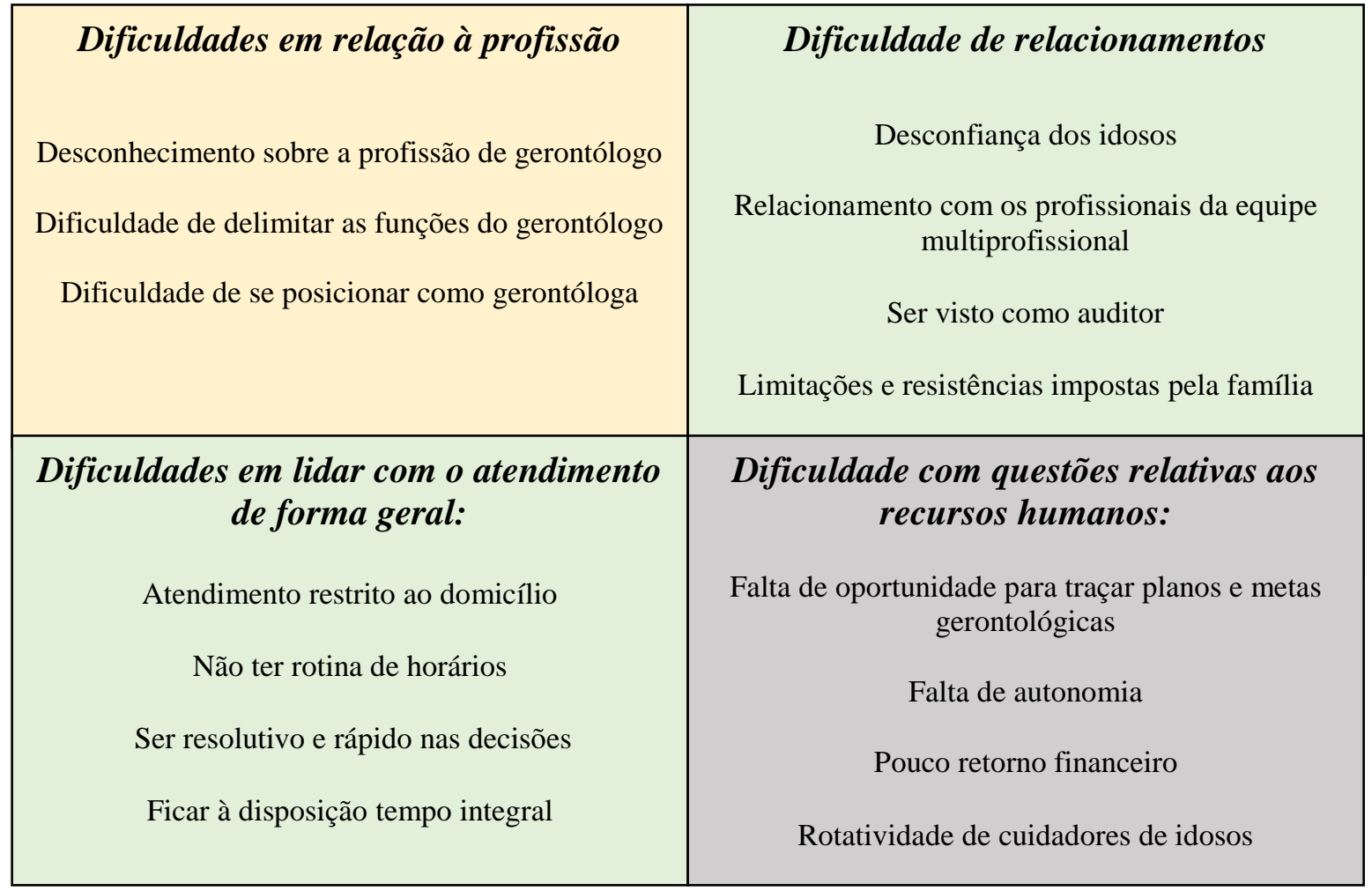

Fonte: Jullyanne Marques Sousa Teixeira, 2017

\subsubsection{Dificuldades em relação à profissão}

Neste grupo encontram-se as dificuldades as quais os gerontólogos enfrentam pelo fato do curso de Graduação em Gerontologia ser novo e pouco conhecido. Em alguns campos de trabalho em que, até pouco tempo atrás, não existia o profissional gerontólogo na equipe interprofissional, como é o caso do atendimento domiciliar, os gerontólogos apresentam 
dificuldade em posicionar-se e de compreender quais são/ serão suas funções dentro da instituição.

É importante que ações as quais divulguem a profissão continuem sendo realizadas, assim como os gerontólogos já atuantes na área, promovam, diariamente, sua profissão a fim de que as dificuldades como estas relatadas, deixem de existir e, consequentemente, deixem de desmotivar o profissional. Também é necessário que haja segurança e, principalmente, confiança do profissional ao colocar-se no mercado de trabalho, independentemente de sua área de atuação.

\subsubsection{Dificuldades em lidar com o atendimento de forma geral}

Algumas dificuldades em relação ao atendimento mencionadas no discurso de algumas gerontólogas apareceram também, curiosamente, nas falas de suas colegas como motivos para trabalharem na assistência domiciliar como, por exemplo, não possuir rotina de horários e a obrigatoriedade de apresentar agilidade nas tomadas de decisão. Todas as áreas de atuação apresentam vantagens e desvantagens. Dificuldades como estas são inerentes e particulares a cada empresa e/ou indivíduo. O objetivo do estudo é somente apresentar as dificuldades para que as empresas e profissionais tenham conhecimento e que assim consigam refletir e discutilas em âmbito profissional.

\subsubsection{Dificuldade de relacionamentos}

Conforme discutido no decorrer do estudo, o gerontólogo atuante na área domiciliar está em contato com todos os envolvidos, cuidadores, equipe interprofissional, idosos e familiares. Verifica-se nas dificuldades apontadas, que há dificuldade de relacionamento com todos os grupos atuantes.

\subsubsection{Dificuldade com questões relativas aos recursos humanos}

Algumas gerontólogas apontaram as dificuldades relativas à área de recursos humanos como, por exemplo, a remuneração do gerontólogo e seu planejamento de trabalho.

Assim como as dificuldades relacionadas ao atendimento, as dificuldades deste grupo estão associadas às empresas de cuidadores, portanto, faz-se necessário que discussões sobre o assunto sejam realizadas, periodicamente, na esfera profissional. 


\section{CONSIDERAÇÕES FINAIS}

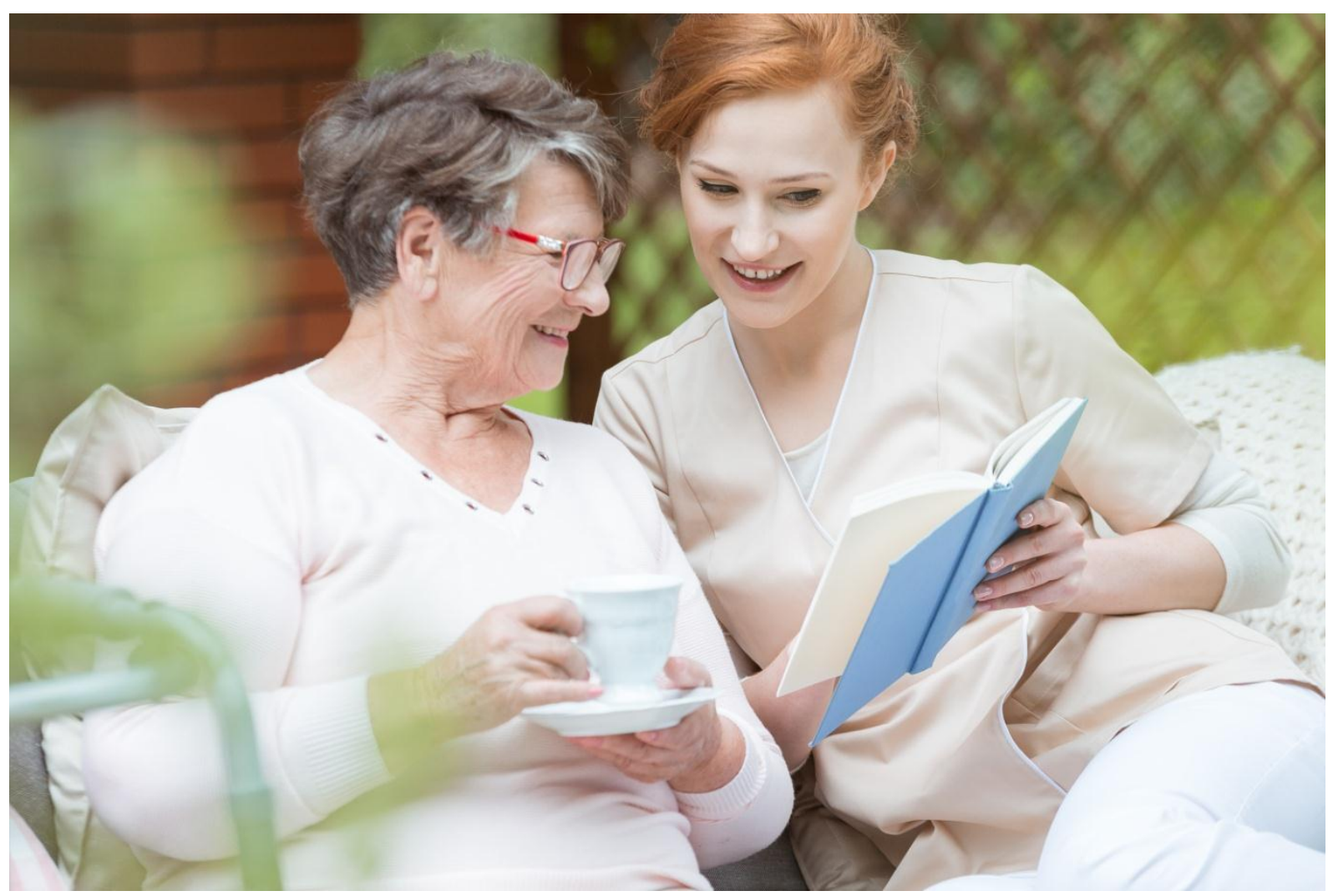

Fonte: Banco de Imagens Shutterstock, 2017 


\section{CONSIDERAÇÕES FINAIS}

A compreensão dos significados do gerontólogo como gestor do cuidado formal domiciliar mostra que este profissional, com sua formação generalista e interdisciplinar sobre o envelhecimento e a velhice, consegue desenvolver uma visão integral do idoso, compreender e atender suas necessidades biopsicossociais.

Observa-se com clareza, no depoimento das participantes, que o gerontólogo é percebido e igualmente percebe-se como gestor do cuidado. Neste cenário, fazem parte do escopo das atribuições do gerontólogo: administrar as situações do cotidiano, garantir segurança dos idosos e cuidadores, monitorar a evolução do processo saúde-doença, gerenciar conflitos, organizar a estrutura e dinâmica do atendimento e promover o bem-estar entre idosos, familiares e cuidadores.

$\mathrm{Na}$ fala das cuidadoras nota-se que estas consideram o gerontólogo como agente integrador do cuidado, neste sentido, é possível refletir sobre a importância deste profissional na equipe interprofissional, uma vez que, possui um vasto conhecimento sobre o envelhecimento e a velhice. O gerontólogo, neste contexto, transitará, não somente entre a equipe a fim de contribuir com intervenções e estratégias para um cuidado adequado às condições do idoso, como também se relacionará com os familiares e cuidadores, de modo a compreender, organizar e atender a todas as demandas e expectativas do cuidado.

A categoria mais citada pelas cuidadoras foi referente à orientação realizada pelo gerontólogo, por isso entende-se que apesar de capacitadas no cuidado ao idoso, as cuidadoras identificam no gerontólogo uma fonte de conhecimento e apoio técnico contínuo. Assim, fazse importante que os profissionais gerontólogos não estejam apenas voltados a ministrar cursos de capacitação para cuidadores de idosos, como também devem mirar à manutenção e atualização destes profissionais, promovendo assim, educação continuada dos cuidadores.

Para que o gerontólogo possa criar e conduzir programas socioeducativos é essencial que ele esteja sempre atualizado e qualificando-se a fim de oferecer um serviço de excelência e reconhecido pela população em geral.

Aos gerontólogos, ressalta-se a necessidade de reconhecer o diferencial e a relevância de seu trabalho dentro de um serviço de atenção ao idoso. Apesar de ser sabido que muitos profissionais não conhecem/compreendem a função do Gerontólogo, todas as cuidadoras entrevistadas possuem uma visão definida e bastante positiva em relação à atuação deste profissional. E, além disso, enfatizaram que a falta de uma gestão gerontológica no serviço gera insegurança ao cuidador, desconforto para família, além de afetar, diretamente, a qualidade do cuidado prestado ao idoso. 
Foi apontado pelas gerontólogas que no campo profissional existe uma dificuldade de delimitar suas funções. Espera-se que, com a regulamentação da profissão, os demais profissionais e as instituições passem a ter mais clareza quanto às atribuições do Gerontólogo. Por enquanto, esperamos que este estudo possa contribuir para uma compreensão mais assertiva sobre as competências e a atuação do gerontólogo no contexto do cuidado domiciliar. Pesquisas nos demais serviços, os quais se podem atuar, devem ser realizadas em prol de reconhecimento do potencial deste novo profissional por parte da sociedade.

Cabe ressaltar que o resultado deste estudo, embora traga uma experiência rica de significados, apresenta algumas limitações, principalmente por ter sido realizado apenas com gerontólogos e cuidadores, não se expandindo aos demais envolvidos, como os familiares, idosos e os demais profissionais que compõem a equipe interprofissional, impossibilitando assim, uma visão mais íntegra sobre o significado do gerontólogo no cuidado domiciliar.

Além disso, ainda existem poucas empresas de cuidadores com a gestão gerontológica. Sendo essa uma limitação encontrada para realizar a pesquisa com um número maior de gerontólogos, já que não foi possível encontrar neste cenário de atuação mais gerontólogos trabalhando no momento da pesquisa.

O estudo mostrou a importância de a gestão ser realizada pelo profissional gerontólogo. Porém, é notória a necessidade de continuarmos desenvolvendo este tipo de pesquisa para que seja possível oferecer um serviço que leve em consideração à qualidade do cuidado prestado, as demandas e dificuldades da família, do idoso, dos cuidadores, do gerontólogo e da equipe interprofissional. 


\section{REFERÊNCIAS}

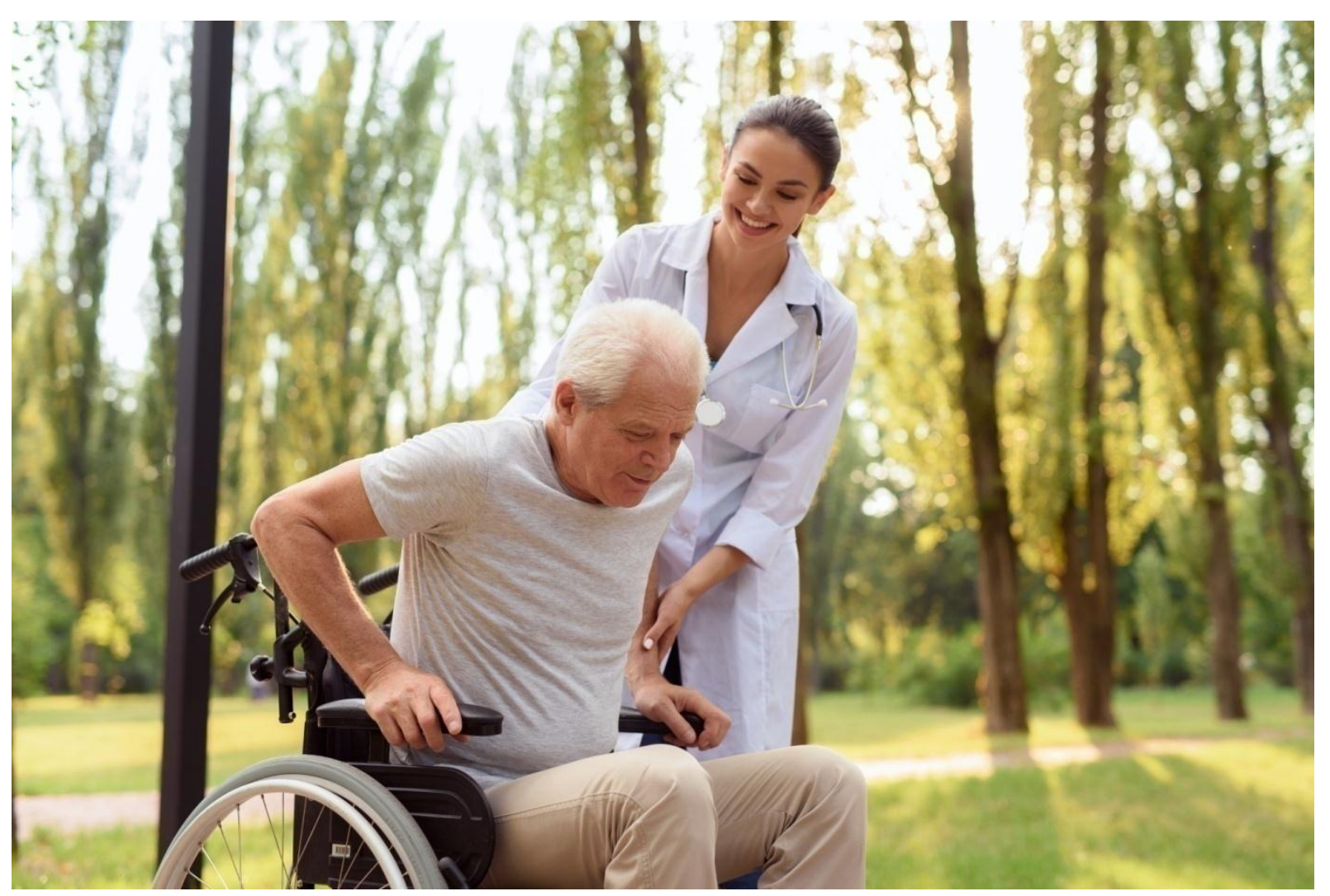

Fonte: Banco de Imagens Shutterstock, 2017 


\section{REFERÊNCIAS}

Angelo M. O Contexto Familiar. In: Duarte YAO, Diogo MJE. Atendimento domiciliar: um enfoque gerontológico. São Paulo: Editora Atheneu; 2005.

Areosa, SV., Coutinho, Henz, LF., Lawisch, D. \& Areosa, RC. (2014). Cuidar de si e do outro: estudo sobre os cuidadores de idosos. Psicologia, Saúde \& Doenças, 15(2), 482-494.

Arias-Rojas M, et al. Cuidadores familiares de personas con enfermedad crónica em las regiones de frontera colombiana: perfil y carga percibida de cuidado. Rev. Fac. Med. Vol. 62, 2014.

Augusto, Fernanda; Silva, Ivanete e Ventura M. Filhos cuidadores: escolha, mudanças e desafios. Childcaregivers: choice, changesandchallenges. Revista Kairós Gerontologia. São Paulo, 2009. v.12 (2).

Batista MPP. Reflexões sobre o processo de trabalho de acompanhante de idosos do Programa de Acompanhante de Idosos (PAI) no município de São Paulo, SP (Brasil). Dissertação de Mestrado. Faculdade de Medicina da Universidade de São Paulo. São Paulo. 2013.

Bertolucci PHF, et al. O Mini-exame do estado mental em uma população geral. Impacto da escolaridade. Arq. Neuro-psiquiatr., v. 52; 1994. 1-7 p.

Berzins MV, Watanabe HAW. A violência doméstica contra a pessoa idosa. In: Falcão, DVS. A Família e o Idoso: desafios da contemporaneidade. 2 Edição.Campina, SP: Papirus; 2010. P. 151.

BRASIL. Ministério da Saúde. Secretaria de Atenção à Saúde. Departamento de Atenção Básica. Envelhecimento e saúde da pessoa idosa. Brasília: Ministério da Saúde; 2006.

BRASIL. Política Nacional de Internação Domiciliar. Brasília DF, 10 de fevereiro de 2006.

Brêtas ACP. Yoshietome AY. Conversando com que gosta de cuidar de idosos no domicílio. In:Duarte YAO, Diogo MJE. Atendimento domiciliar: um enfoque gerontológico. In Duarte YAO, Diogo MJE. Atendimento domiciliar: um enfoque gerontológico. São Paulo: Editora Atheneu; 2005. P.111.

Brucki SMD, et al. Sugestões para o uso do mini-exame do estado mental no Brasil. Arq. Neuro-psiquiatr. V.61; 2003. 777-781 p

Cachioni M., Neri AL. Educação e gerontologia: desafios e oportunidades. - Revista Brasileira de Ciências do Envelhecimento Humano. Passo Fundo, 99-115 - jan./jun. 2004

Camarano AA. Cuidados de Longa duração para população idosa: um novo risco social a ser assumido? Rio de Janeiro; Ipea, 2010.

Camarano AA. Os novos idosos brasileiros: muito além dos 60? IPEA. Rio de Janeiro; 2004.

Castro FF. A sociologia fenomenológica de Alfred Schultz. Universidade Federal do Pará; 2012.

CENSO DEMOGRÁFICO 2010. Características da população e dos domicílios: resultados do universo. Rio de Janeiro: IBGE, 2011.

COREN- Conselho Regional de Enfermagem de Santa Catarina (2015). Curso para Cuidador de Idosos. PARECER COREN/SC No 002/CT/2015/PT. Autarquia Federal criada pela Lei No $^{\circ}$ 5.905/73.

Cornélio GF. Caracterização da educação em saúde dos cuidadores formais em institutições de longa permanência para idosos de Botucatu-SP. Dissertação de Mestrado. Faculdade de Medicina de Botucatu, Universidade Estadual Paulista, 2010.

Costa GA. Tríplice visão do envelhecimento: longevidade, qualidade de vida e aspectos biopsicossociais da velhice. Ed. Da UFU. Uberlândia; 2003.

Couto AM, Castro EAB. Cuidador familiar de idoso dependente: vivências de cuidar em Contexto domiciliar e implicações para a enfermagem. Tese. Universidade Federal de Juiz de Fora. Juiz de Fora / Minas Gerais.

Crivaro ET, Almeida IS, Souza IEO (2007). O cuidar humano: articulando a produção acadêmica de enfermagem ao cuidado e ao cuidador. R Enferm UERJ, Rio de Janeiro; 15(2):248-54. Rio de Janeiro: Fiocruz, 2002.

Dal Ben LW. Dimensionamento do pessoal de enfermagem em assistência domiciliaria: percepção de gerentes e enfermeiros. São Paulo, 2005.

Duarte YAO, Diogo MJE. Atendimento domiciliar: um enfoque gerontológico. In Duarte YAO, Diogo MJE. Atendimento domiciliar: um enfoque gerontológico. São Paulo: Editora Atheneu; 2005.

Duarte YAO, Lebrão MA. O cuidado gerontológico: um repensar sobre a assistência em gerontologia. In: Pessini L, Barchifontaine CP. Bioética e Longevidade Humana. Edições Loyola. São Paulo: Centro Universitário São Camilo, 2006. P.467.

Duarte YAO. Manual dos formadores de cuidadores de pessoas idosas. São Paulo: Secretaria Estadual de Assistência e Desenvolvimento Social e Fundação Padre Anchieta, 2009.

Falcão DVS, Baptista MN. Avaliação psicológica de família com idosos. In: Falcão, DVS. A Família e o Idoso: desafios da contemporaneidade. 2 Edição.Campina, SP: Papirus; 2010. P 13.

Falcão DVS, Bucher-Maluschke. Os conflitos nas Relações Familiares de Idosos com Doença de Alzheimer: contexto clínico e jurídico. In: Falcão, DVS. A Família e o Idoso: desafios da contemporaneidade. 2 Edição.Campina, SP: Papirus; 2010. P 129. 
Falcão DVS, Lopes A. A formação e atuação professional em gerontologia no Brasil: atenção à velhice e ao envellhecimento no século XXI. In: Falcão, DVS. A Família e o Idoso: desafios da contemporaneidade. 2 Edição.Campina, SP: Papirus; 2010. P. 233.

Falcão DVS. A família e o idoso: desafios da contemporaneidade. São Paulo: Papirus; 2010.

Falcão DVS. Doença de Alzheimer: um estudo sobre o papel das filhas cuidadoras e suas relações familiares (Tese de Doutorado). Universidade Federal de Brasília; 2006.

Ferreira CG, Alexandre TS, Lemos ND. Fatores Associados à Qualidade de Vidade Cuidadores de Idosos em AssistênciaDomiciliária. Saúde Soc. São Paulo, v.20, n.2, p.398-409, 2011

Ferreira MEMM. Ser cuidador: um estudo sobre a satisfação do cuidador formal de idosos. Dissertação. Instituto Politécnico de Bragança. 2012.

Figueiredo D, Sousa L. (2008). Percepção do estado de saúde e sobrecarga em cuidadores familiares de idosos dependentes com e sem demência. Revista Portuguesa De Saúde Pública, Vol. 26, N.O 1

Floriani CA, Schramm FR. Atendimento domiciliar ao idoso: Problema ou solução?. Cad. Saúde Pública, Rio de Janeiro; 2004 jul-ago. p. 986-994.

Floriano LA, Azevedo RCS, Reiners AAO, Sudré MRS (2012). Cuidado realizado pelo cuidador familiar ao idoso dependente, em domicílio, no contexto da estratégia de saúde da família. TextoContextoEnferm, Florianópolis; 21(3): 543-8.

Folstein MF, et al. "Mini-Mental State": a pratical method for grading the cognitive state of patients for the clinician. JournalofPsychiatricResearch, v.12; 1975. 189-198 p.

Gavião ACD. Aspectos psicológicos e o contexto domiciliar. In: Duarte YAO, Diogo MJE. Atendimento domiciliar: um enfoque gerontológico. In Duarte YAO, Diogo MJE. Atendimento domiciliar: um enfoque gerontológico. São Paulo: Editora Atheneu; 2005. P.173.

Gratão ACM. Demanda do Cuidador Familiar com Idoso Demenciado. Dissertação (Mestrado em Enfermagem Fundamental) - Escola de Enfermagem de Ribeirão Preto, Universidade de São Paulo, Ribeirão Preto, 2006.

Gratão ACM. Sobrecarga Vivenciada por Cuidadores de Idosos na Comunidade. Tese de Doutorado (Enfermagem Fundamental) - Escola de enfermagem de Ribeirão Preto, Universidade de São Paulo, 2010.

Gutierrez BAO, Silva HS, Guimarães C, Campino AC. Impacto econômico da doença de Alzheimer no Brasil: é possível melhorar a assistência e reduzir custos?. Ciência \& Saúde Coletiva, 2014.

Hudson RN, et al. Guidelines for the Psychosocial and Bereavement Support of Family Caregivers of Palliative Care Patients. Journal Palliative Medicine, Volume 15, Number 6. Monash University, Melbourne, Australia, 2012.

Huyer G. A thesis submitted to the Faculty of Graduate and Postdoctoral Studies in partial fulfillment of the requirements for the degree of Master of Science in Health Systems. A thesis submitted to the Faculty of Graduate and Postdoctoral Studies in partial fulfillment of the requirements for the degree of Master of Science in Health Systems. Telfer School of Management University of Ottawa, 2018.

Jesus MCP et al. A fenomenologia social de Alfred Schultz e sua contribuição para a enfermagem. Revista Escola de Enfermagem USP; 2013.

Kawasaki K, Diogo MJD. Assistência domiciliária ao idoso: perfil do cuidador formal - parte I. Rev. Esc. Enfermagem- USP; 2001.

Kesselring A, et al. Emotional and physical demands on caregivers in home care to the elderly in Switzerland and their relationship to nursing home admission. European Journal os Public Health. Vol 11. No 3. 2001.

Lima AMM. Graduação em Gerontologia: da inovação pedagógica à formação da identidade profissional do gerontólogo. revista Kairós, São Paulo, Caderno Temático 4, ago. 2009, pp. 19-31

Luzardo AR, Gorini MIPC, Silva AP. (2006). Características de idosos com doença de Alzheimer e seus cuidadores: uma série de casos em um serviço de neurogeriatria. Texto contexto - enferm. [online]. Vol.15, n.4, pp. 587-594. ISSN.

Macedo FMF, Boava DLT. Fenomenologia Social: Possibilidades para a Pesquisa Organizacional. VII Encontro de Estudos Organizacionais da ANPAD; 2012.

Maslach C, Schaufeli WB, Leiter MP. Job Burnout Annual Review Psychology, Palo Alto, 2001. v. 52, p. 397 422.

Melo AFM, Perracini MR. Avaliando e adaptando o ambiente doméstico. In:Duarte YAO, Diogo MJE. Atendimento domiciliar: um enfoque gerontológico. In Duarte YAO, Diogo MJE. Atendimento domiciliar: um enfoque gerontológico. São Paulo: Editora Atheneu; 2005. P.187.

Melo RC, Lima-Silva TB, Cachioni M. Desafios da formação em Gerontologia. Revista KairósGerontologia, 18(N.o Especial 19), Temático: "Envelhecimento Ativo e Velhice", 2015.

Merighi MAB, Gonçalves R, Rodrigues IG. Vivenciando o período puerperal: uma abordagem compreensivada Fenomenologia Social. RevBrasEnferm 2006 nov-dez; 59(6): 775-9.

MINISTÉRIO DO TRABALHO E EMPREGO. Classificação Brasileira de Ocupações. Disponível em: Www.mtecbo.gov.br/cbosite/pages/home. Acesso em: maio 2017 
Monaco F, Guimarães VN. Gestão da qualidade total e qualidade de vida no trabalho: o caso da gerência de administração dos correios. RAC, v.4, n.3, set./dez., p.67-88, 2000.

Neri AL, Sommerhalder C. A varias faces do cuidado e do bem-estar do cuidador. In: Neri AL, et al. Cuidar de Idosos no context da família: questões psicológicas e sociais. 2a Edição. Campinas, SP: Editora Alínea, 2006. P. 9 .

Oliveira AB. Aspectos do cuidado do idoso e seus cuidadores: Um revisão de literatura. Formiga, Minas Gerais; 2010 [acesso em 05 out 2015]. Disponível em: https://www.nescon.medicina.ufmg.br/biblioteca/imagem/2801.pdf Oliveira EM, Spiri WC. Programa Saúde da Família: a experiência de equipe multiprofissional. Rev Saúde Pública; 2006

Parasuraman A, Berry LL, Zeithaml VA. A conceptual model os serviceqaulityand it simplications for future research. Journal os Marketing, Chicago, v. 49; 1985. 41-50 p.

Paterson JE, Zderad LT. Humanistic Nursing (1976). United States of America: Wiley Biomedical Publication; 1976. 2. Nascimento ERP, Trentini M. O cuidado de enfermagem na UTI: teoria Humanística de Paterson e Zderad. Rev Latino-amEnferm. 2004; 12 (2): 250-57.

Pavarini SCI, Neri AL. Compreendendo dependência, independência e autonomia no contexto domiciliar: conceitos, atitudes e comportamentos. In Duarte YAO, Diogo MJE. Atendimento domiciliar: um enfoque gerontológico. São Paulo: Editora Atheneu; 2005. P.49.

Pereira F, Mata MAP, Pimentel MH. A emergência da gerontologia como profissão e o seu reconhecimento social em Portugal. Atas do V Encontro doCIED, 2012.

Pereira F. Gerontólogo: A construção de uma nova profissão na área da saúde. In: VI Congresso Português de Sociologia; 25 a 28 de junho; Lisboa; 2008. [acesso em 05 out 2014]. Disponível em: http://www.aps.pt/vicongresso/pdfs/402.pdf

Ribeiro MTF, Ferreira RC, Ferreira EF, Magalhães CS, Moreira AN. Perfil dos cuidadores de idosos nas instituições de longa permanência de Belo Horizonte, MG.Ciênc Saúde Colet. 2008.

Ribeiro RN. Cuidador de idoso: discussão do processo de regulamentação da profissão pela análise discursiva de audiências públicas. São Paulo: Instituto dePsicologia da Universidade de São Paulo, 2015.

Ricarte LFCS. (2009). Sobrecarga do cuidador informal de idosos dependentes no Concelho da Ribeira Grande. Dissertação de Mestrado em Ciências de Enfermagem, Instituto de Ciências Biomédicas Abel Salazar da Universidade do Porto.

Rodrigues RAP, Andrade OG, Marques S. Representacionessociales Del cuidado Del anciano em trabajadores de salud em unancianato. Rev. LatAm Enfermagem. 2001.

Schoenmakers B, et al. Factors determining the impact of care-giving on caregivers of elderly patients with dementia a systematic literature review. Academic Centre of General Practice, Catholic University Leuven, Kapucijnenvoer 33, Blok J, Box 7001, 3000 Leuven, Belgium.

Schultz A. A fenomenologia Del mundo social. Buenos Aires: Paidos; 1972.

Schultz A. A fenomenologia Del mundo social. Buenos Aires: Paidos; 1974.

Silva L, Galera ASF, Moreno V. Encontrando-se em casa: uma proposta de atendimento domiciliar para família de idosos dependentes. São Paulo: Acta Paul Enferm; 2007.

Silva GPS. Experiência de mulheres prímaras com a cesariana: estudo fundamentado na fenomenologia social de Alfred Schütz. Dissertação de Mestrado, Escola de Enfermagem a Universidade de São Paulo; 2013.Síntese de indicadores sociais : uma análise das condições de vida da população brasileira : 2015 / IBGE, Coordenação de População e Indicadores Sociais. - Rio de Janeiro : IBGE; 2015.Tomasini SLV. Envelhecimento e planejamento do ambiente construído: em busca de um enfoque interdisciplinar. Revista Brasileira de Ciências do Envelhecimento Humano, Passo Fundo, 76-88 - jan./jun. 2005

Trelha CS, Revaldaves EJ, Yussef SM, Dellaroza MSG, Cabrera MAS, Yamada KN, et al (2006). Caracterização de idosos restritos ao domicílio e seus cuidadores. Revista Espaço para a Saúde; 8 (1): 20-7.

Vidal FDL et al (2012). Prática de cuidar/cuidado aos portadores de transtornos mentais: concepção dos enfermeiros. Revista Ciência \& Saúde, Porto Alegre, v. 5, n. 2, p. 99-106.

Vieira CPB, Fialho AVM, Freitas CHA, Jorge MSB (2011). Práticas do cuidador informal do idoso no domicílio. Rev. bras. enferm. [online]. Vol.64, n.3, pp.570-579. ISSN 0034-7167.

Vieira L, Nobre JRS, Bastos CCBC, Wanderley MB. Publicização do papel do cuidador domiciliar. São Paulo: IEE/PUC-SP, Brasília, Secretaria de Assistência Social - MPAS; 2012.

Watson J. (1979). Nursing: the philosophy and science of caring. Boston: Little, Brown; c.

Watson J. (1985). Nursing: human science and human care: a theory of nursing. 2nd printing. New York (US): National League for Nursing; 15.

Wendt NC, Crepaldi MA. A Utilização do Genograma como Instrumento de Coleta de Dados na Pesquisa Qualitativa. Universidade Federal de Santa Catarina; 2007.

Zarit SH, Reever KE, Back-Peterson J. (1980). Relatives of the impaired elderly: Correlates offeelings of burden. The Gerontologist, 20, 649-655. 


\section{Apêndice A - QUESTIONÁRIO CUIDADORES}

UNIVERSIDADE DE SÃO PAULO

ESCOLA DE ARTES, CIÊNCIAS E HUMANIDADES

QUESTIONÁRIO CUIDADORES

Nome:

\section{Dados Sociodemográficos}

1. Sexo: Masculino ( ) Feminino ( )

2. Idade: anos

3. Bairro onde Mora:

4. Religião:

5. Natural de:

6. Mora em São Paulo há:

7. Bairro onde trabalha atualmente:

8. Empresa que atua

9. Tempo de empresa:

10. Estado Civil: Solteiro ( ) Casado (a) ( ) Divorciado(a)/Separado ( ) Viúvo (a) ( ) Outros ( )

11. O Sr. (a) tem filho? ( ) Sim ( ) Não

12. Número de Filhos:

13. Anos de estudo:
( ) Sem instrução e menos de 1 ano
( ) 1 a 3 anos
( ) 3 a 7 anos

( ) 8 a 10 anos

( ) 11 a 14 anos

( ) 15 anos ou mais

14. Quão satisfeito o Sr. Está com a sua situação econômica:

( ) Muito insatisfeito ( ) Insatisfeito ( ) Pouco satisfeito ( ) Satisfeito ( ) Muito satisfeito

1. Qual sua renda mensal aproximadamente?

2. Tem curso de cuidador? ( ) Sim ( ) Não

3. Tempo de experiência:

4. A iniciativa de ser cuidador: Iniciativa própria ( ) Familiares ( ) Amigos ( ) Outros ( ) 


\section{UNIVERSIDADE DE SÃO PAULO \\ ESCOLA DE ARTES, CIÊNCIAS E HUMANIDADES}

\section{Roteiro para Perguntas abertas (cuidadores)}

1. Descreva a sua rotina de trabalho.

2. Quais foram os motivos que lhe fizeram trabalhar numa empresa com gestão de um gerontólogo?

3. Para você, como é trabalhar com o gerontólogo na equipe multiprofissional?

4. Fale como foi o início do seu trabalho na empresa.

5. O gerontólogo participou deste processo? Quais foram as atribuições do gerontólogo?

6. Quais são as atribuições do gerontólogo no cuidado domiciliar?

7. Como é a sua relação com o gerontólogo durante o atendimento? Explique.

8. Pra você, qual a contribuição que o gerontólogo traz no cuidado ao idoso?

9. Considerando o trabalho exercido pelo gerontólogo, você está satisfeito?Cite três vantagens de ter um gerontólogo na equipe.

10. Cite três desvantagens de ter um gerontólogo na equipe.

11. No geral, você tem alguma dificuldade de lidar com o atendimento domiciliar sob a supervisão de um gerontólogo? Por quê?

12. O que você espera da atuação do gerontólogo no atendimento domiciliar?

13. Você já trabalhou no ambiente domiciliar sem a gestão gerontológica? Se sim, descreva as diferenças entre este atendimento e o seu atual. 


\title{
Apêndice B - QUESTIONÁRIO GERONTÓLOGOS
}

\author{
UNIVERSIDADE DE SÃO PAULO \\ ESCOLA DE ARTES, CIÊNCIAS E HUMANIDADES \\ QUESTIONÁRIO GERONTÓLOGOS
}

\section{Nome:}

\section{Dados Sociodemográficos}

1. Sexo: Masculino ( ) Feminino ( )

2. Idade: anos

3. Bairro onde Mora:

4. Religião:

5. Natural de:

6. Mora em São Paulo há:

7. Empresa que atua:

8. Tempo de empresa:

9. Estado Civil: Solteiro ( ) Casado (a) ( ) Divorciado(a)/Separado ( ) Viúvo (a) ( ) Outros ( )

10. Você tem filho? ( ) Sim ( ) Não Número de Filhos:

11. Além da Gerontologia, tem outro curso superior? ( ) Sim （ ) Não

12. Qual?

13. Pós - Graduação? ( ) Sim ( ) Não

14. Qual?

15. Quão satisfeito o Sr. Está com a sua situação econômica:

( ) Muito insatisfeito ( ) Insatisfeito ( ) Pouco satisfeito ( ) Satisfeito ( ) Muito satisfeito

16. Qual sua renda mensal aproximadamente?

17. A iniciativa de atuar na assistência domiciliar:

Iniciativa própria ( ) Familiares ( ) Amigos ( ) Outros ( )

18. Tempo de experiência na assistência domiciliar: 


\section{UNIVERSIDADE DE SÃO PAULO \\ ESCOLA DE ARTES, CIÊNCIAS E HUMANIDADES}

\section{Roteiro para Perguntas Abertas Gerontólogo}

1. Pra você, como é atuar como gerontólogo no cuidado domiciliar?

2. Quais foram os motivos que lhe fizeram trabalhar no cuidado domiciliar?

3. Descreva como se deu sua entrada na assistência domiciliar.

4. Descreva sua rotina de trabalho.

5. Quais são suas atribuições como gestor do cuidado domiciliar?

6. Como é sua relação com os responsáveis familiares? Explique.

7. Como é sua relação com os idosos que recebem atendimento? Explique.

8. Como é sua relação com os cuidadores que prestam atendimento? Explique.

9. Como sua atuação contribui para o cuidado ao idoso?

10. No geral, existe alguma dificuldade em exercer a profissão de gerontólogo no ambiente domiciliar? Qual ou quais?

11. Como você avalia sua atuação como gestor do cuidador domiciliar formal?

12. Cite três vantagens de atuar como gerontólogo no cuidado domiciliar.

13. Cite três desvantagens e atuar como gerontólogo no cuidado domiciliar.

14. O que você espera da atuação do gerontólogo no atendimento domiciliar? 


\section{Apêndice C - TERMO DE CONSENTIMENTO LIVRE E ESCLARECIDO}

\section{(CUIDADORES)}

\section{Termo de Consentimento Livre e Esclarecido}

Eu, Jullyanne Marques Sousa Teixeira, mestranda do Programa de Pós-Graduação em Gerontologia da Escola de Artes Ciências e Humanidades - Universidade de São Paulo (USP) realizarei uma pesquisa, cujo título é O Gerontólogo como gestor do cuidado formal domiciliar.

Os participantes da pesquisa serão os cuidadores formais que prestam atendimento ao idoso. Como critérios de inclusão os cuidadores deverão atender os pacientes de maneira formal eserem supervisionados presencialmente por gerontólogos.

Tenho como objetivos: Verificar o significado do gerontólogo como gestor do cuidado domiciliar, na perspectiva dos cuidadores formais; Analisar a qualidade do serviço prestado pelo gerontólogo considerando o depoimento dos cuidadores envolvidos no serviço; Conhecer as motivações que levam os cuidadores a trabalhar na assistência domiciliar.

O risco da pesquisa é mínimo.

A pesquisa beneficiará a todos os envolvidos, uma vez que, a partir dos resultados será possível melhorar a qualidade do serviço prestado pelo gerontólogo, considerando as necessidades da família, idosos e cuidadores.

Para tanto, gostaria que o(a) Sr.(a) participasse desta pesquisa, na qual comprometemo-nos a respeitar o seu direito de:

1. Ter liberdade de participar ou deixar de participar do estudo, sem que isso lhe traga algum prejuízo.

2. Manter o seu nome em sigilo absoluto, sendo que o que disser não resultará em prejuízo na assistência recebida.

3. Interromper a conversa, caso sinta-se incomodado em continuar a conversa.

4. Conversar na hora que the for conveniente, informando-me um horário e data em que possa se sentir mais confortável.

5. Garantia de receber uma resposta a alguma dúvida durante ou após a entrevista. Deixo o telefone: (11) 98430-0237 Jullyanne Marques Sousa Teixeira, para que possa obter mais esclarecimentos ou informações sobre o estudo e a sua participação. 
Caso aceite participar, farei algumas perguntas e precisarei gravar o que o senhor falar. Esta entrevista fará parte de uma pesquisa científica e será apresentada em congressos e publicada em revistas da área da saúde, no sentido de contribuir para um melhor conhecimento.

Obrigado pela atenção,

Entrevistadora

São Paulo, 2017

Após ter lido e compreendido as informações acima, concordo em participar desta pesquisa, concedendo a entrevista. Estou ciente dos meus direitos relacionados acima e que estes serão respeitados pelos pesquisadores.

Entrevistado

O Termo de Consentimento Livre e Esclarecido será composto por duas vias, sendo a primeira pertencente ao entrevistado e a segunda pertencente ao entrevistador.

Endereço: Av. Arlindo Bétio, 1000 - Ermelino Matarazzo - CEP: 05508-000 - São Paulo - SP - Telefone: 3091-1046 - e-mail: cep-each@.usp.br 


\section{Apêndice D - TERMO DE CONSENTIMENTO LIVRE E ESCLARECIDO (GERONTÓLOGOS)}

\section{Termo de Consentimento Livre e Esclarecido}

Eu, Jullyanne Marques Sousa Teixeira, mestranda do Programa de Pós-Graduação em Gerontologia da Escola de Artes Ciências e Humanidades - Universidade de São Paulo (USP) realizarei uma pesquisa, cujo título é O Gerontólogo como gestor do cuidado formal domiciliar.

Os participantes da pesquisa serão os gerontólogos envolvidos no cuidado. Como critérios de inclusão os gerontólogos deverão pertencer a alguma empresa que presta atendimento domiciliar e atuar diretamente e presencialmente no cuidado com idoso.

Tenho como objetivos: Levantar a partir do depoimento dos gerontólogos, quais são suas atribuições desempenhadas como gestor do cuidado no ambiente domiciliar, e qual o significado de sua atuação; Verificar a satisfação do gerontólogo no ambiente de trabalho; Conhecer as motivações que levam os gerontólogos a trabalhar na assistência domiciliar.

O risco da pesquisa é mínimo.

A pesquisa beneficiará a todos os envolvidos, uma vez que, a partir dos resultados será possível melhorar a qualidade do serviço prestado pelo gerontólogo, considerando as necessidades da família, idosos e cuidadores.

Para tanto, gostaria que o(a) Sr.(a) participasse desta pesquisa, na qual comprometemo-nos a respeitar o seu direito de:

6. Ter liberdade de participar ou deixar de participar do estudo, sem que isso lhe traga algum prejuízo.

7. Manter o seu nome em sigilo absoluto, sendo que o que disser não resultará em prejuízo na assistência recebida.

8. Interromper a conversa, caso sinta-se incomodado em continuar a conversa.

9. Conversar na hora que lhe for conveniente, informando-me um horário e data em que possa se sentir mais confortável.

10. Garantia de receber uma resposta a alguma dúvida durante ou após a entrevista. Deixo o telefone: (11) 98430-0237 Jullyanne Marques Sousa Teixeira, para que possa obter mais esclarecimentos ou informações sobre o estudo e a sua participação. 
Caso aceite participar, farei algumas perguntas e precisarei gravar o que o senhor falar. Esta entrevista fará parte de uma pesquisa científica e será apresentada em congressos e publicada em revistas da área da saúde, no sentido de contribuir para um melhor conhecimento.

Obrigado pela atenção,

Entrevistadora

São Paulo, 2017

Após ter lido e compreendido as informações acima, concordo em participar desta pesquisa, concedendo a entrevista. Estou ciente dos meus direitos relacionados acima e que estes serão respeitados pelos pesquisadores.

Entrevistado

O Termo de Consentimento Livre e Esclarecido será composto por duas vias, sendo a primeira pertencente ao entrevistado e a segunda pertencente ao entrevistador.

Endereço: Av. Arlindo Bétio, 1000 - Ermelino Matarazzo - CEP: 05508-000 - São Paulo - SP - Telefone:

3091-1046 - e-mail: cep-each@.usp.br

\section{Anexo A - APROVAÇ̃̃o DO COMITÊ DE ÉTICA EM PESQUISA}




\section{ESCOLA DE ARTES, CIÊNCIAS Plotoforma E HUMANIDADES - EACH/USP}

\section{PARECER CONSUBSTANCIADO DO CEP}

\section{DADOS DO PROJETO DE PESQUISA}

Título da Pesquisa: O GERONTÓLOGO COMO GESTOR DO CUIDADO DOMICILIAR

Pesquisador: Jullyanne Marques

Área Temática:

Versão: 2

CAAE: 55497716.7 .0000 .5390

Instituição Proponente: UNIVERSIDADE DE SAO PAULO

Patrocinador Principal: Financiamento Próprio

\section{DADOS DO PARECER}

Número do Parecer: 1.558 .610

\section{Apresentação do Projeto:}

Partindo do número crescente de pessoas em todo o mundo vivenciando a velhice e paralelamente a isso a presença de doenças crônicas e incapacitantes, o que faz com que os idosos necessitem de cuidados constantes e atenção integral no âmbito domiciliar, surge a necessidade do cuidador de idosos formal. Para suprir essa demanda, muitas empresas já contam com a oferta de cuidadores de idosos para atendimento domiciliar, outras poucas estão utilizando um método novo de assistência à saúde do idoso, com a inclusão de gerontólogos na gestão do cuidado domiciliar.

Trata-se de pesquisa qualitativa. A pesquisa realizada em um serviço de cuidadores de empresas localizadas em São Paulo. A amostra será constituída por 20 participantes sendo cinco cuidadores formais, cinco familiares, cinco idosos e cinco gerontólogos. Os depoimentos serão coletados por meio de questionário aberto e instrumentos validados. A análise dos dados qualitativos terá como referencial metodológico a fenomenologia social.

\section{Objetivo da Pesquisa:}

, com os seguintes objetivos: verificar na perspectiva dos idosos, cuidadores formais e familiares o significado da atuação do gerontólogo como gestor do cuidado formal domiciliar; verificar a satisfação do gerontólogo no ambiente de trabalho; e averiguar a qualidade do serviço do gerontólogo.

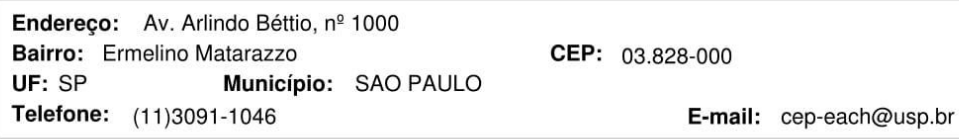




\section{ESCOLA DE ARTES, CIÊNCIAS OPlotoformo E HUMANIDADES - EACH/USP}

Continuação do Parecer: 1.558 .610

\section{Avaliação dos Riscos e Benefícios:}

- Tanto o risco psicológico mínimo quanto os benefícios para o participante constam no TCLE.

Comentários e Considerações sobre a Pesquisa:

A pesquisa é relevante para a área da Gerontologia.

Considerações sobre os Termos de apresentação obrigatória:

Todos os termos obrigatórios estão anexados na Plataforma Brasil conforme exigências da Resolução 466/2012 relacionada à Ética em pesquisa com Seres Humanos do Conselho Nacional de Saúde-MS.

\section{Recomendações:}

Não há recomendações.

Conclusões ou Pendências e Lista de Inadequações:

Projeto Aprovado.

Não há pendências.

Considerações Finais a critério do CEP:

Este parecer foi elaborado baseado nos documentos abaixo relacionados:

\begin{tabular}{|c|c|c|c|c|}
\hline Tipo Documento & Arquivo & Postagem & Autor & Situação \\
\hline $\begin{array}{l}\text { Informações Básicas } \\
\text { do Projeto }\end{array}$ & $\begin{array}{l}\text { PB_INFORMAÇÕES_BÁSICAS_DO_P } \\
\text { ROJETO 686820.pdf }\end{array}$ & $\begin{array}{c}09 / 05 / 2016 \\
13: 30: 05\end{array}$ & & Aceito \\
\hline $\begin{array}{l}\text { TCLE / Termos de } \\
\text { Assentimento / } \\
\text { Justificativa de } \\
\text { Ausência }\end{array}$ & $\begin{array}{l}\text { Termo_Consentimento_Gerontologos_M } \\
\text { odificado.docx }\end{array}$ & $\begin{array}{l}07 / 05 / 2016 \\
20: 14: 23\end{array}$ & Jullyanne Marques & Aceito \\
\hline $\begin{array}{l}\text { TCLE / Termos de } \\
\text { Assentimento / } \\
\text { Justificativa de } \\
\text { Ausência }\end{array}$ & $\begin{array}{l}\text { Termo_Consentimento_Familiares_Modi } \\
\text { ficado.docx }\end{array}$ & $\begin{array}{l}07 / 05 / 2016 \\
20: 08: 19\end{array}$ & Jullyanne Marques & Aceito \\
\hline $\begin{array}{l}\text { TCLE / Termos de } \\
\text { Assentimento / } \\
\text { Justificativa de } \\
\text { Ausência }\end{array}$ & $\begin{array}{l}\text { Termo_Consetimento_Idosos_Modificad } \\
\text { o.docx }\end{array}$ & $\begin{array}{l}07 / 05 / 2016 \\
20: 06: 25\end{array}$ & Jullyanne Marques & Aceito \\
\hline $\begin{array}{l}\text { TCLE / Termos de } \\
\text { Assentimento / } \\
\text { Justificativa de } \\
\text { Ausência }\end{array}$ & $\begin{array}{l}\text { Termo_Consentimento_Cuidadores_Mo } \\
\text { dificado.docx }\end{array}$ & $\begin{array}{l}07 / 05 / 2016 \\
20: 05: 23\end{array}$ & Jullyanne Marques & Aceito \\
\hline Folha de Rosto & Folha_rosto.pdf & $\begin{array}{c}26 / 04 / 2016 \\
16: 32: 41 \\
\end{array}$ & $\begin{array}{l}\text { Rosa Yuka Sato } \\
\text { Chubaci }\end{array}$ & Aceito \\
\hline
\end{tabular}

Endereço: Av. Arlindo Béttio, 꾸 1000

Bairro: Ermelino Matarazzo

UF: SP Município: SAO PAULO

CEP: $03.828-000$

Telefone: (11)3091-1046

E-mail: cep-each@usp.br 


\section{ESCOLA DE ARTES, CIÊNCIAS Plotoforma E HUMANIDADES - EACH/USP}

Continuação do Parecer: 1.558.610

\begin{tabular}{|c|c|c|c|c|}
\hline $\begin{array}{l}\text { Declaração de } \\
\text { Instituição e } \\
\text { Infraestrutura }\end{array}$ & Autorizacao_Coleta.doc & $\begin{array}{c}\text { 01/04/2016 } \\
09: 48: 36\end{array}$ & Jullyanne Marques & Aceito \\
\hline $\begin{array}{l}\text { TCLE / Termos de } \\
\text { Assentimento / } \\
\text { Justificativa de } \\
\text { Ausência }\end{array}$ & Termo_Consentimento_Familiares.docx & $\begin{array}{l}\text { 01/04/2016 } \\
09: 48: 05\end{array}$ & Jullyanne Marques & Aceito \\
\hline $\begin{array}{l}\text { TCLE / Termos de } \\
\text { Assentimento / } \\
\text { Justificativa de } \\
\text { Ausência }\end{array}$ & $\begin{array}{l}\text { Termo_Consentimento_Gerontologos.do } \\
\text { cx }\end{array}$ & $\begin{array}{l}01 / 04 / 2016 \\
09: 47: 27\end{array}$ & Jullyanne Marques & Aceito \\
\hline $\begin{array}{l}\text { TCLE / Termos de } \\
\text { Assentimento / } \\
\text { Justificativa de } \\
\text { Ausência }\end{array}$ & Termo_Consentimento_Idosos.docx & $\begin{array}{c}01 / 04 / 2016 \\
09: 46: 34\end{array}$ & Jullyanne Marques & Aceito \\
\hline $\begin{array}{l}\text { TCLE / Termos de } \\
\text { Assentimento / } \\
\text { Justificativa de } \\
\text { Ausência } \\
\end{array}$ & $\begin{array}{l}\text { Termo_Consentimento_Cuidadores.doc } \\
x\end{array}$ & $\begin{array}{l}\text { 01/04/2016 } \\
09: 46: 04\end{array}$ & Jullyanne Marques & Aceito \\
\hline $\begin{array}{l}\text { Projeto Detalhado / } \\
\text { Brochura } \\
\text { Investigador }\end{array}$ & ProjetoDetalhado.doc & $\begin{array}{c}01 / 04 / 2016 \\
09: 44: 42\end{array}$ & Jullyanne Marques & Aceito \\
\hline
\end{tabular}

\section{Situação do Parecer:}

Aprovado

Necessita Apreciação da CONEP:

Não

SAO PAULO, 24 de Maio de 2016

Assinado por:

Beatriz Aparecida Ozello Gutierrez

(Coordenador)

Endereço: Av. Arlindo Béttio, № 1000

Bairro: Ermelino Matarazzo

UF: SP

Município: SAO PAULO

Telefone: (11)3091-1046
CEP: $03.828-000$

E-mail: cep-each@usp.br 


\section{Anexo B - CATEGORIAS CUIDADORES (íntegra)}

\section{MOTIVOS PORQUE OS CUIDADORES TRABALHAM COM O GERONTÓLOGO}

\section{Por indicação}

verdade foi uma indicação na época, eu trabalhava numa casa quando eu encontrei a primeira empresa que eu trabalhei com a gestão do gerontólogo, que foi a X, eu encontrei uma moça que prestava serviço pra essa empresa no ônibus, e ela começou a conversar comigo. (C.II.2.1) Com o gerontólogo é mais próximo. Eu fui para a empresa por causa da minha amiga né? Uma opção minha, mas junto com a minha amiga, pois na época que entrei na empresa ela já estava trabalhando ai eu pedi pra ela me indicar. (C.XIII.2.2)

\section{Poder administrar melhor o cotidiano}

E eu queria trabalhar num local em que eu saísse, visse as pessoas. Que eu pudesse estudar, pegar condução, eu não aguentava mais ficar dia e noite no mesmo lugar. Ai ela começou a perguntar pra mim, ... pediu que eu fosse lá fazer uma ficha, disse que trabalhava numa empresa “assim, assim, assado”, e disse que tinha a gestão do gerontólogo, e que por isso teria como eu estudar, que eu teria uma dinâmica pré-estabelecida de trabalho, que daria pra eu ter uma vida, e ai foi quando me indicaram o primeiro paciente. (C.II.2.2)

\section{Ter um profissional realizando a gestão do atendimento}

Foi pela oportunidade de trabalhar com um profissional que fizesse nossa gestão, para que eu não me sentisse sozinha.(C.VIII.2.1)

...e disse que tinha a gestão do gerontólogo, que teria como eu estudar, que eu teria uma dinâmica pré-estabelecida de trabalho...(C.II.2.2)

\section{Evitar a insegurança e solidão de ser cuidador}

Foi pela oportunidade de trabalhar com um profissional que fizesse nossa gestão, para que eu não me sentisse sozinha.(C.VIII.2.1)

\section{Ter supervisão das atribuições do cuidador}


eu preferi trabalhar assim, porque a gente tem todo um apoio referente a família, porque as vezes eles abusam, as vezes você entra pra fazer uma coisa e quando você vai ver já está fazendo outra. (C.XII.2.1)

você entrou hoje na empresa, você vai descrever tudo aquilo que você vai fazer e é tudo certinho, com contrato. E na realidade, quando você vai trabalhar registrado pra alguém, direto, sem o gerontólogos supervisionando, não é isso que acontece, eles te contratam como cuidador e você termina sendo a empregada, fazendo comida, passando roupa, fazendo tudo. (C.XII.2.2)

\section{Não precisar tratar diretamente com a família}

eu procurei essa empresa, porque aqui você tem todo um apoio, e você não trata diretamente com a família, você trata direto com o gerontólogo. (C.XII.2.3)

\section{MOTIVOS PARA OS CUIDADORES TRABALHAREM COM O GERONTÓLOGO}

\section{Gerenciar os conflitos familiares}

...o gerontólogo entre outras coisas ele administra também a família né?O que a família espera da gente, administra as crises né, eu acho muito legal isso, o gerontólogo administrando as crises da família. (C.I.2.1)

passou a posição da família, eu acho que é um administrador da crise pra mim, sabe? O que a família espera de mim, o que eu tenho que fazer, e assim fica mais tranquilo. (C.I.5.4)

Ah! No meu caso eu tenho um relacionamento próximo com o gerontólogo somente quando preciso de ajuda com as crises familiares. (C.I.7.6)

Pra mim é sempre administrar a crise da família, em primeiro, segundo e terceiro lugar. É sempre bom ter com quem contar pra pedir socorro. (C.I.10.8)

Eu entro em contato com o gerontólogo pra passar problemas familiares, quando eles acontecem né? (C.V.7.3)

A gerontóloga teve uma participação grande, a família era muito difícil de lidar, foram gerando alguns transtornos, e eu fui passando pra gerontóloga e fui mantendo a calma, pra poder não sair e abandonar o serviço. (C.XIII.5.5)

ajuda também a necessidade e problemas da família, tanto no financeiro como no cotidiano. (C.XIII.9.10) 
resolve os problemas da casa e da família quando a gente não consegue resolver, aí procura o gerontólogo. (C.XV.7.5)

\section{Dar segurança para o paciente e cuidador}

É mais seguro, né? Porque é importante o paciente ter todo esse grupo de apoio. (C.I.3.2)

Me dá muita segurança, porque eu sei que tem alguém que tem um conhecimento maior do que о теи(C.VI.3.4)

que está aqui tanto para a minha segurança, como para a segurança do paciente. (C.IV.3.5) ela está lá para ajudar, totalmente, então me dá muita segurança, eu sei que eu tenho curso de cuidadora, as vezes vai estou capacitada, mas algo as vezes vai além da minha capacitação, $e$ eu sei que eu tenho uma parceira, então, liberdade, segurança...e acho que é isso. (C.VI.10.15) A segurança que você tem com o gerontólogo, é a insegurança que você tem sem. Porque tem coisas que, mesmo que a gente tenha feito o curso de cuidadora, que a gente não esta capacitada, e ai acaba assustando, então o gerontólogo é isso, eu sei que tem uma pessoa que está acima de mim, qualquer coisa que vir acontecer que eu me assustar, é só eu ligar e estará com ela. Eu tive muita insegurança sem o gerontólogo. (C.VI.14.18)

a gente fica mais segura...(C.IX.3.2)

eu me sinto bem mais segura. (C.IX.11.9)

você se sente mais seguro, é como se a pessoa tivesse mais suporte em relação ao que você tem que fazer, o que você tem que praticar. (C.XIV.14.6)

\section{Orientar a equipe de cuidadores}

As gerontólogas também dão dicas, olha Adriana faz isso, faz aquilo. Eu acho muito importante essas orientações, pra eu poder levar melhor. (C.I.3.3)

A gerontóloga me indica livros sobre como lidar com o paciente, com a doença, sobre temas de cuidado. (C.I.8.7)

eu acho muito bom, porque você chega no lugar que você vai trabalhar já orientado, com toda a dinâmica já passada. (CII.3.3)

o gerontólogo foi comigo pessoalmente, primeiro me orientou, conversou comigo.(C.II.5.5) você tem sempre pra quem pedir alguma coisa, e caso acontece alguma coisa tem sempre quem te oriente quem te ajude. (C.II.10.15)

Muito, o gerontólogo que realizou toda a orientação sobre a rotina do paciente, sobre a dinâmica da família, do residencial. Foi maravilhoso!(C.III.5.3)

porque ela orienta e direciona para fazer cada qual o seu trabalho. (C.III.10.9) 
Espero que o gerontólogo possa sempre informar, quanto mais informação ele puder trazer pra gente eu acho muito importante, com relação a parte cognitiva, a locomoção, as patologias.(C.III.13.11)

Olha, eu preciso dele pra saber o que eu faço, quando estou com o paciente, acontece alguma coisa e eu não sei o que fazer, pra tirar uma duvida minha em relação ao paciente. (C.IV.7.17) eu não tenho o curso e apesar da experiência, tem coisas que eu não sei fazer, que o gerontólogo me ensinou, como foi o caso, eu aprendi a medir pulso, pressão, tudo com o gerontólogo (C.IV.3.7)

Se o aparelho está quebrado a gente pega um paciente acamado, o gerontólogo vai lá, dá ideia, ajuda, ensina como fazer. (C.IV.3.8)

Pra gente não confundir o que é pulsação com pressão, respiração. O gerontólogo sabe de tudo isso, ele estudou, sabe muito mais do que nós. Muita gente que fez curso, também não sabe, então precisa muito do gerontólogo. Particularmente pra mim é uma mão na roda. (C.IV.3.9)

O gerontólogo me instrui, e eu não tenho nenhuma dificuldade de manter e administrar, do jeito que o gerontólogo me explica eu faço e está tudo bem, soluciono bem o problema, não tenho dificuldade nenhuma. (C.IV.12.25)

ela observa bastante, dá orientações pra nós que somos cuidadoras né, dentro do trabalho ali, ela orienta, tira nossas dúvidas. (C.V.8.4)

A gente tem sempre orientação, né? Ela está ali perto se a gente precisa de alguma coisa. (C.V.10.5)

Ela está vendo a evolução do paciente de perto, então se a gente precisa de alguma coisa, no momento a gente liga e já tem uma orientação no momento. (C.V.10.6)

Orienta a gente, esta sempre ali, no que a gente precisa ela está nos orientando. (C.V.13.7) O bom é porque ela auxilia a gente assim, vamos supor, como no meu caso eu não tenho curso de cuidadora, ela me auxilia muito, eu estou aprendendo muito com ela, entendeu? A saber cuidar da paciente, tem coisas que a gente não sabe que eu pergunto pra ela. (C.VII.3.1) se eu tenho duvida é pra gerontóloga que eu pergunto, ela está ali para me auxiliar, então nesse sentindo, é muito bom. (C.VII.3.2)

Então, qualquer dúvida que eu tinha era a gerontóloga que me socorria. Hoje não, hoje eu já tiro de letra, são poucas coisas que eu ligo pra gerontóloga pra perguntar, é mais sobre a pressão dela mesmo, porque eu tenho medo da pressão dela subir muito e eu ficar aqui com ela sozinha sem saber o que fazer, mas nas outras coisas eu já tiro de letra. Eu já sei dobrar ela. (C.VII.5.6) 
Então assim, a gerontóloga me auxilia muito, vamos supor, se hoje a pressão dela está muito alta, por exemplo, a gerontóloga fala "Olha Erlania, faz isso, isso e isso”, ou se a pressão dela está baixa, entendeu? Pra mim, ela me ajuda na questão da saúde da paciente. (C.VII.7.9) Hoje de manhã eu fui tirar a pressão dela, não estava normalizada, aí demorei um pouquinho, fiquei atenta, cuidei dela, deixei ela se acalmar, sentei ela direitinho, aí fui e tirei de novo. E tudo isso a gerontóloga que me ensinou. (C.VII.8.10)

A gerontóloga me ajudou, me deu umas orientações sobre o que eu tinha que fazer, me deu apoio. (C.VIII.5.2)

Eu acho que tudo que acontece eu passo para a gerontóloga, e ela me explica minhas dúvidas.(C.VIII.12.8)

é muito importante, a gente aprende mais, tem mais orientação, é muito importante, eu acho. (C.IX.2.1)

qualquer dúvida a gente pergunta, e tem conhecimento dos problemas dela, e eles passam pra gente como que a gente deve fazer. (C.IX.3.3)

o gerontólogo me ajudou muito, orientando, me falando como que eu tinha que tratar, me comportar. Como que eu tinha que me comportar diante da reação ou comportamento da pessoa que às vezes muda. A idade muda e ele orienta como temos que nos comportar, agir e falar. (C.IX.5.4)

se você tem dúvida você tem pra quem recorrer. (C.IX.10.6)

a gente aprende mais coisa, adquiri mais conhecimento. (C.X.3.1)

me explicando o que eu deveria fazer. Dando todo o suporte e todas as explicações. (C.X.5.2) Explica a situação do paciente, dá treinamento, fala qual é a rotina do paciente, o que pode serfeito e o que não pode ser feito. (C.X.6.3)

Muito bom, porque ele tira nossas duvidas, porque a gente esclarece algumas duvidas sobre o paciente que a gente não consegue ajudar na hora. (C.XI.3.1)

eu entro em contato com ele, por exemplo, se a pressão do paciente aumenta muito, aí eu pergunto se pode dar uma medicação, ou se tá passando mal, eu pergunto se posso chamar a emergência, pergunto como devo proceder. (C.XI.7.7)

se o paciente passar mal, ou se tiver uma queda ou um aumento de pressão, eu posso perguntar pra ela como proceder, ajudar nas minhas duvidas do dia a dia (C.XI.10.9)

e a gerontóloga foi falando "vai fazendo assim, vai fazendo assim, que vai dando certo"'(C.XII.5.8)

A gente tem a vantagem de recorrer em caso de dúvidas, de uma intercorrência, de um esclarecimento que venha primeiro do gerontólogo, toda a parte de orientação. (C.XIV.10.4) 


\section{Zelar pela saúde do idoso}

Eu vejo que é uma pessoa que está sempre preocupada com os remédios, com a administração dos medicamentos, se estão fazendo efeito, com a alimentação, com indicação de outros profissionais, médicos, preocupados com outras atividades para o idoso fazer, eu vejo o gerontólogo sempre preocupado. (C.I.6.5)

Ela ajuda muito com marcação de consultas, idas ao médico.(C.III.6.6)

ele vai visitar os pacientes, saber como o paciente está, aferir pressão, controlar os sinais vitais, saber se está tendo alguma melhora (C.IV.6.13)

Ele cuida da parte do paciente, por ele ser idoso né? Cuida de toda a parte da saúde, da nutrição, do desenvolvimento dele, se ele está fazendo as coisas de iniciativa própria, tudo isso, o desenvolvimento, o desempenho dele no decorrer do tratamento, porque a gente está ali com ele, né? Pra ver se está tendo alguma evolução. (C.V.6.2)

estar acompanhando, todos os detalhes, estar atenta se ela passa mal, se vai para o hospital, se está tomando medicação direitinho, se está comendo direitinho, tudo, tudo, tudo, ela está 100\% ligada a paciente que eu cuido, ela é minha parceira. (C.VI.8.13)

A gerontóloga faz praticamente o papel do médico, não é? Está adiantando o serviço pro médico, porque se acontecer alguma coisa ele vai saber pela gerontóloga também, ela faz o monitoramento do paciente.(C.VIII.6.4)

Ela está sempre atenta em como a paciente está, em relação a saúde, ao comportamento da mente. (C.IX.8.5)

passar alguma coisa se precisar que tá faltando da paciente, se material de medicamento aí ela já resolve. (C.IX.10.8)

e para o paciente, é se está precisando de alguma coisa, alguma medicação, se mudou alguma medicação, se mudou alguma postura ou rotina de cuidado(C.XI.6.5)

sobre a medicação mesmo, ajudar a organizar. (C.XI.10.11)

acompanhar no hospital, marcar exames, ver se está precisando de algum auxílio referente a comida, verificar se a família está contribuindo para o bem da paciente. (C.XII.6.14)

Incentivando a gente a levar o paciente pra tomar sol, fazer caminhada, coisas da rotina. (C.XII.8.16)

Dá pra contar com a gerontóloga para monitorar o paciente e pra ajudar a gente a ensinar mais as cuidadoras. (C.VIII.10.7)

Contribui pra melhoria do paciente né, da saúde dele. (C.X.8.5) 


\section{Adaptar o ambiente para a segurança do idoso}

Ali, aquela família precisa de um gerontólogo, pra falar "olha, você tem que arrumar isso, o banheiro não pode ter tanto degrau, era degrau pra entrar na banheira, degrau pra entrar no Box.”. (C.I.14.9)

A questão da segurança da residência, dando suporte pra família, falando o que é bom e o que não é, acho que isso é muito importante. (C.XIII.8.7)

\section{Auxiliar o cuidador no processo de adaptação com o paciente}

Gerontólogo te passa tudo antes, você já sabe o que o paciente tem, sabe qual a situação geral, você não chega perdida, você chega preparada para o que você vai encontrar.(C.II.3.4) Os primeiros contatos com o paciente, eu acredito que quem faça é o gerontólogo que faz, de conhecer o paciente, saber o que ela precisa, saber a real necessidade dele, eu acredito que o gerontólogo faz isso.(C.II.6.7)

como tem o gerontólogo, eu não senti nenhum dificuldade. Ele viu que eu não tinha muita habilidade com algumas coisas, por ter falado que eu tinha experiência também só de um ano, aí me testou com uma paciente não exigia muito do meu conhecimento, não era acamada, eu dava banho, ajudava no banheiro, eu pude me identificar com o cuidado e com a paciente. Ele me orientou muito.(C.IV.4.10)

me levou até a paciente, me explicou tudo pessoalmente, como ela era, como ela não era, se ela gostava de fazer algumas coisas ou não, me explicou sobre todos os cuidados ao falar, paciência, saber respeitar a individualidade da paciente, se ela quisesse sair eu levava, se ela não quisesse eu ia conversando calmamente, e ela ia indo. (C.IV.5.11)

A gerontóloga me passou que a paciente estava com um quadro de depressão, então toda minha tratativa foi diferente, se ela não tivesse me instruído como eu ia saber?(C.IV.5.12)

ele participou desde o começo, assistindo minha entrevista, me observou no começo...é uma pessoa com quem eu posso contar sempre, ela participou da minha adaptação na casa do paciente. (C.VI.5.6/7)

Então, é uma paciente que pra locomoção é mais difícil. E a gerontóloga me incentivou, sempre falando "você vai conseguir, estou aqui, vou te ajudar", então é uma parceira, isso me fez ter confiança, porque eu queria desistir no começo, e hoje está super fácil de trabalhar, por essa parceria. (C.VI.12.16)

até hoje é complicado, tudo é um processo, assim, como todo idoso ela não gosta de tomar banho, então a gente tem que ter todo aquele jeitinho pra ela fazer a higiene pessoal, então no 
começo aqui foi muito complicado, e quem me auxiliou muito aqui foi a gerontóloga. (C.VII.4.3)

Nossa, a gerontóloga foi fundamental, me auxiliou muito mesmo. Vou dar um exemplo "olha, não tô conseguindo dar banho nela hoje", aí ela falava "olha vai desse jeito, faz dessa forma, vai com jeitinho, se você não conseguir dar banho nela agora de manhã, a tarde você tenta de novo”. (C.VII.5.4)

e nesse sentido, a gerontóloga me ajudou muito, "Não Erlania, se você não conseguir dar banho nela agora de manha, não tem problema, mas não pode ficar sem tomar banho, a tarde você tenta de novo e vai com jeitinho e vai levando ela."(C.IV.5.5)

É interessante para que você fique sabendo sobre o paciente que você cuida antes de entrar na casa. (C.VIII.6.3)

Quando você pega um paciente que você não sabe de nada, ele está sempre ali para explicar. Sozinho não tem como você fazer nada. O gerontólogo vai te explicar, deixa a gente informada, passa sobre a família, o que a família gosta o que ela não gosta. (C.X.10.6)

explicando como o paciente era, eu já fui para a residência sabendo quais eram os cuidados que o paciente precisava. (C.XI.5.3)

me ajudou passando como a paciente era, o que fazer (C.XII.5.6)

muitas vezes ela falava pra eu relevar, as vezes a paciente queria mais açúcar, ficava brava, $e$ a gerontóloga me orientava a ir tirando aos poucos, pra ir adaptando. (C.XII.5.7)

no começo, ela me ajudou com isso, com as coisas especificas da paciente, até porque eu não conhecia a paciente, né? Eu não conhecia a rotina dela. (C.XII.5.9)

Orientar quando as cuidadoras iniciam numa casa, acompanhar a rotina, passar os problemas que a paciente tem (C.XII.6.11)

Em relação às tarefas, a rotina que é necessária, a orientação dos procedimentos que devem ser tomados dentro da necessidade do paciente. (C.XIV.6.2)

o gerontólogo me ajudou me falando o que eu podia fazer com o paciente. (C.XV.5.1)

\section{Administrar as informações sobre o idoso}

Depois foi comigo até o paciente, ficou me acompanhando por telefone, principalmente porque eu nunca tinha trabalhado numa empresa assim, e eu gostava que tinha esse acompanhamento, e o acompanhamento de relatório, porque você mantém uma dinâmica que dá pra se comunicar com toda a equipe, fica tudo documentado, e eu gosto disso, que as coisas sejam claras e documentadas.(C.II.5.6) 
Gerontólogo ajuda a cuidar, não de forma direta, mas indiretamente ele ajuda bastante, ajuda na prevenção de riscos, ajuda no cuidado, tipo a Dona Maria Odete, ela precisa de acompanhamento, porque sem acompanhamento a gente fica sem informação sobre o dia-adia dela. (C.VIII.8.6)

O gerontólogo da um seguimento, por exemplo, ela chega aqui deixa escrito o que tem que fazer e todas nós seguimos, ninguém vai falar não, não vou fazer isso. (C.IX.14.10)

Quando eu preciso de alguma informação, quando acontece alguma coisa com o paciente, eu sempre entro em contato pra manter ele informado. (C.X.7.4)

e tenho uma boa relação com a gerontóloga, nos comunicamos bem. Sobre o paciente, o que aconteceu, tudo o que acontece com o paciente eu passo pra gerontóloga. (C.VIII.7.5)

\section{Identificar e atender as necessidades do paciente}

...depois encaminha alguém no perfil daquele paciente para executar esse serviço que é a necessidade dele né? (C.II.6.8)

Ele vê a equipe multiprofissional que vai precisar, cada paciente tem uma necessidade de cuidado, eu acredito que cada um tenha uma equipe diferente, de acordo com a necessidade patológica do idoso né. (C.II.6.9)

porque o paciente se sente seguro por ter sido avaliado por um profissional capacitado e que realmente conhece as necessidades do idoso. (C.II.10.11)

Então precisa mesmo ter uma pessoa que administre tudo, que vá lá veja como está o paciente, vê como o paciente está a aderir a cuidadora, se o paciente está gostando, se não está gostando, se precisa de mais alguma coisa (C.IV.2.3)

Assiste a condição do paciente, numa totalidade, de todas as necessidades do paciente. (C.XIV.6.1)

ajudando a identificar alguma dificuldade porque muitas vezes a paciente fica agitada e às vezes a gente não sabe como proceder, e aí a ajuda dela é bastante importante. (C.III.5.6) ele dá muito apoio com relação a identificar sintomas e dificuldades, principalmente na parte cognitiva.(C.III.8.8)

\section{Orientar o paciente e seus familiares}

imagina uma pessoa que fica perdida? A maioria dos pacientes que eu cuidei, ou mora com uma pessoa que não fica lá com ele, ou mora sozinha. Eles necessitam de ajuda, muitas vezes eles não têm informação nem pra saber como eles mesmos cuidam deles. Então, mesmo que eles precisem de uma cuidadora por um determinado período, quem vai orientá-lo se não o 
gerontólogo? As vezes ele nem conhece as próprias necessidades. Então eu acho que o gerontólogo é muito importante para o paciente. (C.II.8.10)

\section{Dar suporte integral e eficaz para os cuidadores}

Em casos de ocorrências, você tem um suporte. (C.II.10.12)

Como eu disse, é suporte, porque mesmo com formação, hoje eu já sou formada como auxiliar de enfermagem, tô cursando o técnico, e as vezes o paciente pode vir a ter algum problema que você precisa de uma orientação, e trabalhar numa empresa que tem o gerontólogo, é saber que tem sempre alguém de plantão. (C.II.14.13)

se você se comunicar com ele, imediatamente ele já te responde, já procura orientar, já de imediato, é resposta imediata pra sua dúvida, pro seu questionamento. (C.II.14.14)

eu acho bastante importante, porque dá apoio, você tem um acompanhamento junto com a paciente, você tem um apoio, principalmente na parte cognitiva, como proceder em determinados casos.(C.III.2.1)

É muito importante, e ela é bastante atuante junto à equipe.(C.III.3.2)

Bom, no caso da gerontologia aqui junto com a equipe, é importante por quê? Porque ela está sempre junto.(C.III.6.4)

Apoio junto com aos idosos, apoio junto a equipe. (C.III.10.7)

se eu estou ali e o paciente está precisando de um cuidado que eu não sei, eu literalmente ligo pro gerontólogo e ele soluciona o problema. (C.IV.10.22)

porque se tiver acontecendo algum problema, ele já saberá imediatamente resolve. (C.IV.8.19)

Pra mim é tudo, o gerontólogo estando junto, a gente vai saber o que fazer. (C.IV.3.6)

Já trabalhei sem gerontólogo, e a diferença é que você fica assim "pra quem que eu vou falar?". Não tem ninguém pra você passar o problema do paciente, não tem ninguém com quem você falar, você fica sozinho. (C.V.14.8)

Em termos técnicos, de conhecimento, eu fico mais à vontade, qualquer intercorrência que tiver com ela, eu tenho a quem recorrer, né? (C.VI.2.2)

é algo que me deixa mais segura, eu sei que eu tenho o apoio, eu sei que qualquer coisa que vier acontecer, eu tenho alguém que me dá um suporte. (C.VI.2.3)

Me dá suporte técnico, não só técnico, é uma pessoa que está sempre muito próximo do paciente(C.VI.6.8) está sempre dando assistência, sempre perguntando se está tudo bem, é uma pessoa que me dá total segurança e suporte técnico. (C.VI.6.10) 
eu sei que é uma pessoa que se algo não estiver ao meu alcance, é pra quem eu vou recorrer, eu sei que ela estará comigo, e ela esta capacitada a fazer algo que talvez eu não esteja, mas, assim, só tiver alguma eventualidade. (C.VI.13.17)

na hora eu já liguei pra gerontóloga falei o que tinham me passado, que no plantão anterior ela não tinha conseguido comer, ela pediu pra eu ler o relatório do cuidador, descobrimos que deram arroz, salada e frango pra ela a noite, ela não está acostumada a comer isso, então ela não vai comer. (C.VII.7.8)

Se a gente tem algum problema assim, a gente pede socorro, ao invés de chegar em qualquer outra pessoa da empresa, eu sempre vou para a gerontóloga. (C.VII.10.12)

se você precisa de alguma coisa se você chama ela vem e já te ajuda a resolver a situação né, se for uma emergência. (C.IX.10.7)

e qualquer emergência né, que a gente não consegue solucionar na mesma hora, a gente pode chamar o gerontólogo pra nos auxiliar melhor. (C.XI.3.2)

ela está lá para o que a gente precisar né? (C.XI.6.6)

se eu precisar da ajuda dela, se de repente o paciente está passando mal, eu não estou conseguindo fazer o que tenho pra fazer, se eu pedir a ajuda dela, ela vai me ajudar. (C.XI.8.8) algum problema que eu não sei resolver, aí eu entro em contato porque sei que ela vai saber resolver. (C.XII.7.15)

acompanhamento que ela dá referente ao trabalho, as vezes a gente tem duvida referente a algumas coisas, e elas estão ali preparadas pra resolver. (C.XII.10.18)

sempre que a gente precisa ela está apta a resolver, a ir atrás, as vezes ela não tem naquele momento, mas ela fala "eu vou investigar, eu vou ver o que eu posso fazer, e vai atrás." (C.XII.13.19)

O gerontólogo me aconselha, tentando tirar um pouco por menos, né? E sempre tentando deixar a situação calma e tranquila. (C.XIII.7.6)

sempre que a gente precisa a gerontóloga está disposta a ajudar... é poder ter alguém pra contar. (C.XIII.9.9/11)

Só o fato de ela estar passando na residência toda semana já é uma segurança pra gente, tanto no suporte de estar nos monitorando, como no suporte de algum material que precise com urgência. (C.XIII.13.12)

dá suporte para o cuidador no caso, para aquele que está acompanhando, né? (C.XIV.6.7)

Quando eu preciso de alguma coisa eu ligo pro gerontólogo, ou quando eu preciso saber de alguma coisa, ele vai lá, ou se eu estou indecisa com alguma coisa do paciente, eu sempre peço ajuda. (C.XV.7.3) 


\section{Unir equipe multiprofissional, familiares e cuidadores}

outra vantagem é que ela é a ponte de união entre uma cuidadora e outra. (C.III.10.10)

é uma pessoa que nos deixa a vontade, porque tem muita intimidade com o paciente e com a gente. (C.VI.6.9)

ela seria como se fosse uma espécie de mediadora, entre a gente e a família da paciente. Então assim, a gerontóloga é como se fosse uma ponte de ligação, entre nós cuidadoras e a família, seria uma ponte, quando nós estamos precisando de alguma coisa, ela nos auxilia perante a família. (C.VII.6.7)

Porque só a cuidadora falando isso pra família tanto faz como tanto fez, então a ajuda do gerontólogo é muito boa. (C.XIII.8.8)

O gerontólogo vai lá, faz as perguntas pro paciente, faz as perguntas pra cuidadora, pra saber como foi durante o dia, durante a semana. Eu acho que tem que ter o gerontólogo né? Porque ele é nosso reforço. Sempre que precisamos de alguma coisa é o gerontólogo que nos dá voz. (C.XV.6.2)

a gente está sempre trocando ideia, sempre trocando informações sobre o trabalho, eu gosto de trabalhar com o gerontólogo porque a equipe fica boa, sempre unida, eu estou gostando por causa disso. (C.V.3.1)

\section{Gerenciar a escala da equipe de cuidadores}

porque se não tiver o gerontólogo como que vai funcionar a equipe?(C.IV.2.1)

Até mesmo se eu estou lá trabalhando, aí a pessoa não chega no horário, não cumpre o horário quem que vai gerenciar ali? Quem que vai estar a parte de tudo aquilo. (C.IV.2.2)

Porque se nós não estivermos gostando daquele paciente, naturalmente nós não vamos ficar ali, e ai o gerontólogo vai nos direcionar para outra casa. (C.IV.2.4)

o gerontólogo é que mais cuida da parte do cuidador, de ver como é que tá, tanto o cuidador, como o paciente. (C.IV.2.5)

Dentro da empresa, além de todos esses serviços com o paciente e o cuidador, o gerontólogo também ajuda fazendo relatório, planilha, pagamentos, vendo se a cuidadora está no horário, qual a pontualidade do cuidador. (C.IV.6.15)

se o cuidador falta, o gerontólogo corre pra arrumar outra pessoa, e aí é aquela correria toda. O gerontólogo não faz só o papel de ir lá e acompanhar o paciente não. (C.IV.6.16) se não tem o gerontólogo, imagina se o cuidador não vai? Então ele está sempre dando um jeito de organizar a escala, os horários, a dinâmica. (C.IV.10.21) 
a organização do pagamento, o gerontólogo que faz toda contagem de horas dos cuidadores, e sabem como e quando que a gente estava na casa. Se eu fui se eu não fui, se eu fiz hora extra ou não. (C.IV.10.23)

Eu tive um problema recente com a escala e o horário, eu falei "Olha, esta escala não esta me favorecendo em nada", na hora ela falou "Não Erlania, eu vou ver isso na empresa e vamos resolver." Então assim, ela não resolve só problema com o paciente, entendeu? (C.VI.10.13) pra gestão da escala, pedir folga, gestão de horários...(C.XI.6.4) ajudar nas nossas folgas (C.XI.10.10) o gerontólogo ajuda na gestão da nossa escala, isso é fundamental. (C.XII.14.20) quando eu preciso de uma folga. O gerontólogo resolve a escala. (C.XV.7.4)

\section{Acompanhar presencialmente o atendimento realizado}

gerontólogo está ali pra fazer visita nas semanas, então ele quer saber tudo o que está acontecendo, mesmo nos dias que ele não foi ele quer estar a parte de tudo. (C.IV.8.18)

Tem que ter visita do gerontólogo, ele precisa saber o que está acontecendo. (C.IV.8.20)

A diferença é o acompanhamento né? Antes de trabalhar na empresa eu tinha o acompanhamento só da família, mas era bem distante. (C.XIII.2.1)

é um acompanhamento. No meu ponto de vista, primeiro, ele zela pela vida do paciente, segundo, pela vida da equipe de cuidadoras.(C.XIII.3.3)

É um acompanhamento muito importante, porque dá um incentivo pra gente, a gente fica mais atento, não é aquele trabalho que está relaxado, que está a Deus dará, a gente está diariamente tentando melhorar.(C.XIII.3.4)

Ele acompanha toda a condição do paciente, da família né? E de nós, está sempre perto. (C.XIV.8.3)

\section{Acolher a equipe de cuidadores, familiares e paciente}

Saber como que está o ambiente, se a gente tá bem, se a gente está gostando, como é que está. (C.IV.6.14)

No meu caso, é uma pessoa que virou uma amiga, se fez minha amiga, como também é uma amiga da paciente, faz mais do que a própria profissão pede. (C.VI.7.11)

Então é uma pessoa que eu fico a vontade pra falar qualquer coisa. (C.VI.7.12) 
liberdade por ser uma pessoa de fácil acesso, por ser uma pessoa que eu tenho liberdade, não tenho medo, não tenho vergonha, não tenho "ah será que eu vou falar, será que eu errei, será que não errei" (C.VI.10.14)

Que ele crie mais intimidade com o paciente, no caso dos profissionais que são os cuidadores, para que eles possam passar orientações cada vez mais esclarecedoras no caso. Ela conhecendo cada vez mais o paciente também auxilia mais o trabalho do cuidador. (C.XIV.13.5)

\section{Não precisar tratar diretamente com a família}

Porque aqui é assim: o gerontólogo determina como que vai ser, e todas nós temos que seguir aquilo. Lá não, lá tinha momentos difíceis que a família toda intervinha, e um falava uma coisa e outro falava outra, e eu ficava no meio, não sabia, e eles não resolviam o que tinha que fazer, e a gente ficava meio atordoada, era difícil, muito difícil. (C.IX.14.10)

Já trabalhei particular né, aí temos que correr pra pedir auxilio da família, qualquer duvida que eu tenho eu preciso ou pedir auxilio pra uma pessoa que saiba mais do que eu, ou pra família mesmo. Faz muita falta o gerontólogo. (C.X1.14.12)

\section{Apoiar no processo de luto}

eu já cuidei de paciente que faleceu na minha mão, e eu tive todo o apoio da gerontóloga, ele estava sempre ali, me orientando me ajudando.(C.XII.3.4)

e o apoio que ela dá né, quando o paciente está ali entrando em óbito você acaba entrando em desespero, principalmente se você está sozinha com ele, e a função da gerontóloga ali é ajudar, te orientar, e você acaba não se sentindo sozinha, né? Eu acho fundamental a força que a gerontóloga dá, o apoio né...(C.XII.3.5)

em casos de óbito a gente tem o acompanhamento bom...(C.XII.10.17)

\section{DIFICULDADES DOS CUIDADORES EM TRABALHAREM SOB A GESTÃO DO GERONTÓLOGO}

\section{Excesso de visitas}

Desvantagem? Aas vezes o gerontólogo me instrui tão bem num paciente, que não precisa ela ir varias vezes, uma ou duas vezes no mês tá bom. (C.IV.11.24) 
Anexo C - CATEGORIAS GERONTÓLOGOS (íntegra)

MOTIVOS PORQUE OS GERONTÓLOGOS TRABALHAM NO CUIDADO DOMICILIAR 


\section{Acreditar no modelo de atendimento domiciliar}

porque eu acredito muito em o modelo da pessoa idosa continuar na sua própria casa.(G.I.2.2) porque você minimiza custos de uma série de situações, você ir pra uma ILPI por exemplo, você descaracteriza o ambiente dela e quando você coloca essa pessoa em casa e faz uma gestão com uma equipe multiprofissional,(G.I.2.3)

\section{Ter a demanda de clientes e cuidadores}

eu tinha já a demanda, e ela apareceu mais ainda na hora que eu coloquei, então assim, o primeiro cliente que veio, eu já tinha uma cuidadora, que por sinal já tinha cuidado desse cliente, entrei em contato com ela, a partir dela eu entrei em contato com mais duas. (G.I.4.5)

\section{Acreditar no trabalho do gerontólogo}

acreditar que o gerontólogo é um especialista na área do envelhecimento que é um profissional diferenciado, com essa visão gerontológica, ampla, biopsicosocial, e faz com que me incentive a trabalhar no cuidado domiciliar, pela importância que se mostra nesse cuidado.(G.II.2.4)

\section{Trabalhar diretamente com o idoso no domicílio}

eu queria ter o contato direto com o cliente, no caso o idoso.(G.II.2.2)

Então, coloquei esse desafio pra mim, de trabalhar nessa área do cuidado domiciliar, junto com o idoso diretamente. (G.II.2.3)

Eu tive muito interesse de saber como era o cuidado dentro de casa. (G.II.3.6)

Na verdade eu queria entender como é essa rotina de home care. (G.III.2.1)

\section{Facilidade de conseguir o emprego}

logo que eu me formei eu comecei a procurar emprego, e foi o setor que foi mais rápido para me oferecer uma proposta e daí por diante que eu acabei indo para mais de uma empresa de assistência domiciliar. (G.IV.2.3)

foi minha primeira oportunidade, e eu acabei aceitando e foi a partir daí que eu comecei a exercer um pouco mais a gerontologia. (G.IV.3.4)

\section{Interesse acadêmico}


Primeiro meu interesse desde a iniciação científica pelo tema de cuidadores e Alzheimer. (G.V.2.9)

Depois eu me apaixonei por este tema e segui ele no TCC(G.V.2.10)

\section{Indicação profissional}

A minha entrada ocorreu por causa da indicação de outra gerontóloga que não poderia mais dar continuidade nesta empresa porque ela conseguiu outro trabalho, e ela me indicou. (G.V.2.13)

Aí eu fui em uma visita, para fazer uma avaliação deste paciente, para ele ser um novo cliente desta empresa, mas, a princípio eu não tinha nada estabelecido que eu ia continuar, na verdade foi uma substituição no primeiro momento (G.V.2.14)

\section{MOTIVOS PARA OS GERONTÓLOGOS TRABALHAREM NO CUIDADO DOMICILIAR}

\section{Realizar a gestão gerontológica do atendimento}

Eu acho que é você ser um gestor mesmo, você ter uma visão de vários ângulos da mesma situação, com muita empatia com todos os ângulos envolvidos, todos. (G.I.1.1) ser gerontólogo no atendimento domiciliar, é importante pra gestão do cuidado e do atendimento. (G.II.1.2)

a maior atribuição é ficar ligado ao idoso, é ficar atento a ele, com esse entendimento gerontológico amplo, porque a demanda pode ser não necessariamente clínica, mas ela pode ser social, ela pode ser familiar, ela pode ser psicológica (G.II.5.18)

o olhar atento ao idoso em todos esses âmbitos é muito importante, e é uma atribuição muito grande do gerontólogo e diferenciada dos outros profissionais. (G.II.5.19)

Essa gestão do cuidado não só nesse cuidado específico do idoso, mas também pensando no bem-estar da família e do cuidador profissional, também é muito importante para se ter um cuidado de qualidade, né? (G.II.5.20)

O gerontólogo contribui pro cuidado realizando a gestão desse cuidado, identificando as demandas, tendo um olhar mais apurado, diferenciado, conseguir resolver os problemas e conflitos familiares, então eu acredito que o gerontólogo é um profissional capacitado e especializado no envelhecimento que consegue entender a heterogeneidade do idoso e as diferenças familiares, diferentes formas de lidar com a família e com o cuidado que será prestado. (G.II.9.24/25) 
no sentido de ter um olhar completo, no sentido de o cuidado não desenvolver só a parte de saúde, mas também a parte familiar, eu acho que é isso que conta na minha atuação, que contribui para realizarmos a gestão do cuidado. (G.III.9.8)

a gente não pensa só na parte da saúde, mas também na parte da rede de suporte social e familiar. (G.III.9.9)

eu faço o gerenciamento para acontecer o cuidado domiciliar, as minhas visitas são pontuais pra admissão do paciente, avaliar qual é a demanda e pensar num perfil de atendimento adequado para ele, que combine o familiar, o paciente e o profissional. (G.IV.1.1)

a vantagem de a gente ter um olhar mais completo sobre o idoso e facilitar no atendimento mais completo pra ele. (G.IV.12.18)

então, o gerontólogo sendo um especialista e estando apto pra fazer essa gestão do cuidado me motiva a trabalhar no cuidado domiciliar. (G.II.2.50)

\section{Capacitar e orientar os cuidadores de idosos}

A primeira coisa que eu fiz foi criar um curso de cuidadores, eu apliquei esse curso num ambiente que eu já tenho. (G.I.3.4)

eu já dei mais três turmas de curso de cuidadores(G.I.3.6)

parte de treinamento, eu participo muito da parte de capacitação dos cuidadores e treinamento. (G.III.5.7)

Fazer o contato e algumas vezes a capacitação de alguns cuidadores. (G.IV.4.6)

Eu acho que eu consegui de alguma forma, primeiro capacitar alguns cuidadores para essa parte de atividades, porque toda vez que eu vou fazer uma visita de supervisão no domicílio eu proponho algumas atividades, deixou outras e peço para eles entregarem depois. (G.IV.9.12) ...transfiro este conhecimento para as pessoas que são leigas em relação a isso. (G.V.1.3) As cuidadoras são orientadas o tempo inteiro (G.V.9.38)

Então o gerontólogo tem um papel fundamental neste processo, tanto de atualizar estes cuidadores diante das tarefas que eles têm... (G.V.1.4)

além de uma capacitação constante né? Uma reciclagem do que eles fazem. (G.V.1.5) no dia-a-dia se eu pego algum erro que eles estão cometendo em relação à classificação de uma doença ou de algum procedimento que não está correto, eu vou no dia-a-dia corrigindo(G.V.5.21)

\section{Dar suporte integral e eficaz para os cuidadores}


você tem que estar com seu telefone ligado o tempo todo, então meu celular está sempre ligado. (G.I.4.7)

ter uma atenção maior e específica com o cuidador, no caso o cuidador profissional, que a gente contrata para estar na casa do idoso. Também é uma demanda do gerontólogo. (G.II.4.8) tirar um pouco do desgaste do cuidador. (G.II.1.5)

Eu sempre tento olha um pouco para o lado do cuidador, sei que é uma profissão bastante complicada, tem uma demanda muito grande e esgota muito, porque além de dar conta do paciente, tem que dar conta da família, então nesse sentido eu acho bem complicado. (G.IV.11.16)

Eu tenho um relacionamento próximo com estas cuidadoras, eu tentei dar liberdade que elas se sentissem a vontade de me procurar todas as vezes que elas tivessem duvida. (G.V.8.30)

E elas se sentem muito a vontade comigo, de me procurar fora dos atendimentos. (G.V.8.33) ...um contato próximo com os cuidadores(G.V.12.53)

\section{Acompanhar presencialmente o atendimento realizado}

eu tenho as equipes nas casas, e a cada 10 dias eu visito o paciente, ou menos, dependendo da situação. (G.I.4.8)

Eu visito os pacientes, eu checo se todo mundo está trabalhando, se tem alguma dificuldade. (G.I.4.10)

a rotina do gerontólogo é fazer as visitas pra identificar a demanda do cuidado, pra identificar a situação do paciente. (G.II.4.10)

a rotina é estar sempre com esses dois olhares, pro cuidador e para o idoso. Fazendo as visitas, acompanhando presencialmente o cuidado. (G.II.4.14)

A maior parte do dia eu faço as visitas domiciliares ...e ligações, o tempo todo no telefone, inclusive no trânsito, junto com o cuidador, com familiar, com paciente, com o pessoal da empresa, enfermeiro. (G.III.4.6)

Não existe uma rotina exata, não posso nem classificar assim, mas dentre tudo o que eu faço, eu tenho que fazer visitas domiciliares pontuais para conhecer o paciente e acompanhar os que são os nossos. (G.IV.4.5)

alguém que está ali para zelar pela qualidade de vida, pelos cuidados que são oferecidos não só pelo nosso profissional que está dentro da casa, mas também de uma forma geral (G.V.9.37)

\section{Administrar o cuidado com o idoso}


a minha paciente ela é muito dura de escovar os dentes, e muito dura de tomar banho, então quando eu converso com ela, ela dá uma melhorada, mas a gente não pode obrigar, então ela esta assim, tem uma descompensação emocional que aconteceu e ela voltou a ter esse comportamento de ser difícil de querer levantar de manhã. (G.I.4.9)

toda segunda-feira quem trabalha no esquema de 24 horas, eu vejo a questão do supermercado, geladeira, então, vou ver geladeira, vejo controle de medicamentos, vejo como está o estoque dos medicamentos, vejo a questão de roupa, como é que está, se está toda certinha. (G.I.4.11) vejo a periodicidade do tratamento médico, agora dia 20 tem que fazer os agendamentos médicos pro mês seguinte, né?... Vejo a periodicidade de dentista, vejo a periodicidade de cabeleireiro, vejo a periodicidade dos serviços. (G.I.5.16/17)

E assim, o lazer...eu sugiro o lazer, tá? Mas, dentro do desenho de cada um dos pacientes, tem pacientes que dá pra sugerir um lazer melhor, outros, nem pensar. Então a única coisa vai ser a conversa, vai ser uma estimulação de memória. (G.I.5.18)

uma vez eu levei essa paciente que eu contei que ela tem os surtos, lá no HC, fiquei lá com ela direto, conversei lá com o psiquiatra, conversei com a equipe, expliquei o que estava acontecendo, eles falaram "olha a gente vai fazer uma analise clinica, mas tudo indica mesmo que ela está tendo um surto" então quer dizer, eu fui a base de todas as informações. (G.I.11.26)

como é um atendimento domiciliar, as vezes você tem que acompanhar consultas médicas. (G.II.13.42)

quando o idoso está melhor eu faço perguntando as coisas para o cuidador e para o próprio paciente, “como foi a sua semana?", "você evitou as quedas?”, "você se alimentou bem?”, “ você ganhou peso?"(G.V.7.28)

então se a gente sente que o idoso está precisando de fono a gente orienta "olha, sentimentos a necessidade da inserção do profissional de fonoaudiologia, etc." E isso tudo vai dando um encaminhamento e uma segurança maior para a família e para o paciente.(G.V.9.42)

\section{Administrar as informações sobre o idoso}

Eu faço geralmente relatórios mensais para os familiares responsáveis a respeito disso. (G.I.4.12)

na comunicação efetiva com a família, com o cuidador, com os cuidados prestados, como a família quer que o cuidado seja feito, então o gerontólogo se mostra muito importante nesta questão da comunicação, e na questão de prezar por um cuidado com qualidade. (G.II.1.3) 
é estar o tempo todo atenta aos cuidados né? WhatsApp é um meio muito importante de comunicação, que dá efetividade na comunicação. (G.II.4.13)

Então é um profissional importante nesse cuidado, atuando como um eixo de todas as informações, que vai direcionar os cuidados e conseguir entender melhor o caso. (G.II.9.26) a gente tem também os grupos de WhatsApp para cada caso...(G.V.5.58)

relatando, fazendo relatório de como este cuidado está sendo feito com ofamiliar ou com quem pediu esse serviço. (G.II.4.15)

Mensalmente eu realizo um relatório sobre cada caso, a evolução que ele teve, se houve algum problema e qual o meu parecer técnico em relação a isso. (G.V.4.17)

...e a sócia que entra em contato comigo se ela necessitar de algum parecer técnico.(G.V.6.27)

e aí a gente faz relatório se for necessário semanal, se tiver acontecendo algum caso, e as sócias pedem reunião extraordinárias com a família também, se a gente achar que é necessário.(G.V.9.47)

\section{Dar orientação e suporte para os familiares}

E a gente se reporta muito aos familiares, tem que conversar muito. (G.I.4.21)

a gente conversa, e muitas vezes nós somos o único elo, único e absoluto da família em relação a afeto. A gente tem a paciência de conversar, de ouvir, de perguntar, porque os familiares não aguentam mais. (G.I.9.25)

A rotina do trabalho é estar o tempo todo ligada no bem-estar do paciente, então disso, vem a preocupação se o paciente está sendo bem cuidado, se a demanda familiar está sendo suprida, então tem essa parte. (G.II.4.7)

Então o gerontólogo, tem uma relação com o responsável muito de estar a disposição e servir aquilo que o responsável precisa, mas sempre de acordo com o que o idoso necessita, o foco ali no cuidado é do idoso, então a gente tem que ter toda aquela "manha" e aquele jeito de lidar com o familiar que as vezes pode ser incompreensível. (G.II.5.22)

E também, eu sinto que a família também se sente mais segura, porque sabe que tem um gerontólogo que acompanha este cuidador, sabe que tem alguém que está olhando varias aspectos né? Diante deste cuidado.(G.V.1.6)

eu converso com o familiar, eu dou todo respaldo pro familiar, qualquer duvida ofamiliar me liga, então eu fico a disposição pra que ele ligue e pergunte. (G.I.5.14)

E também, para uma assistência da família mesmo, né? De tirar algumas dúvida, ajudar, orientar algumas redes de suporte social, ou rede de suporte médica mesmo. ( G.IV.9.13) 


\section{Adaptar o ambiente para a segurança do idoso}

verifico como está a infraestrutura do ambiente, então tem casa que tem câmera eu vou checar pra ver se está tudo funcionando, se está tudo em ordem. (G.I.5.15)

\section{Avaliar o idoso}

eu faço primeiramente uma avaliação bem longa, bem extensa, pra saber tudo, e vai desde questões por exemplo, essa paciente, ela quando criança a mãe faleceu então ela foi entregue para os tios, então ela nunca teve carinho de família, então essa informação pra mim é relevante pra tentar entender que ela não dá carinho para as pessoas, para os netos. (G.I.6.19) Então eu faço uma avaliação bem extensa pra tentar entender como é que é sua relação, como é a relação com a nora, com as crianças e etc. (G.I.6.20)

E quando aparece algum novo cliente eu que realizo as avaliações. (G.V.4.18)

\section{Liderar a equipe}

eu sei que eu sou líder, então eu tenho que ser firme. (G.I.8.23)

e eu tenho a autonomia de falar com cada cuidador individualmente se algo aconteceu que não está dentro do esperado. (G.V.5.22)

Eu sempre exalto o que elas já aprenderam que eu acredito que elas são competentes para aquilo, que eu só estou lembrando alguns pontos. (G.V.8.32)

\section{Ajudar a melhorar a saúde do idoso}

Primeiro que ele melhora do ponto de vista emocional, porque ele se sente seguro. (G.I.9.24) você ver que essa pessoa ela pode melhorar na sua mão, sabe? Nem que seja um pouquinho, e você está preservando os valores dela. (G.I.12.27)

poder dar as melhores orientações para o melhor daquele paciente, que pode até trazer a melhora daquele paciente. (G.II.9.27)

A minha mediação ela tem sido satisfatória, porque os resultados têm sido bons, as famílias têm dado feedbacks positivos em relação a todo o trabalho que tem sido feito nas casas, com os pacientes que estão melhorando aos poucos.(G.V.11.50)

\section{Divulgar a profissão de gerontólogo}

Uma vantagem de trabalhar como gerontólogo no domicílio é a divulgação da profissão, porque eu acho que acaba acontecendo muito boca a boca de uma família para a outra, no sentido de até de me pedirem visitas. (G.IV.12.17) 
os cuidadores ...É um novo nicho que a gerontologia está explorando, é um nicho que tem muito a crescer, então eu acho que estar no domicílio e estar com esses profissionais divulga e engrandece a nossa profissão. (G.V.12.54)

\section{Ser valorizado como gerontólogo}

E eu aprendo muito, eu gosto muito, eu me sinto bem, tem a valorização. (G.I.12.29)

Atuar como gerontólogo no atendimento domiciliar é muito gratificante, porque você tem uma devolutiva diretamente com a família, com o cuidador, com o próprio idoso. (G.II.1.1)

Eu espero que o trabalho do gerontólogo no cuidado domiciliar seja reconhecido como importante, como essencial. (G.II.14.47)

reconhecimento do gerontólogo como um profissional importante, do gerontólogo como um profissional essencial no cuidado, é o que eu espero do cuidado domiciliar, principalmente dos profissionais, principalmente da empresa, mais ainda do que o cuidador, que o idoso e que a família que estão ali participando do cuidado efetivo, agora o reconhecimento da empresa, o reconhecimento dos funcionários, é o que eu espero, é o reconhecimento e entendimento desse cuidado que assim vai facilitar muito mais nosso trabalho e contribuir pra maior qualidade do serviço prestado. (G.II.14.48)

eu espero que cresça muito essa atuação do gerontólogo nesse atendimento, mas de uma forma que seja reconhecida, de uma forma que não seja "ah! É uma mão de obra barata" ai você vai lá e coloca o gerontólogo porque é mais barato, não! Tem que ser reconhecido. (G.III.14.15)

\section{Unir equipe multiprofissional, familiares e cuidadores}

Então nossa rotina gira em torno da família, do idoso e do cuidador. (G.II.4.9)

Então o gerontólogo no cuidado domiciliar é um gestor muito importante, ele é o eixo que vai alinhar os cuidados com a família o cuidador e o idoso. (G.II.5.21)

Eu também sou responsável por fazer o link família e empresa. Então, por exemplo, muitas coisas que eles reclamam na minha visita, eles não reclamam para o profissional diretamente. Então eu tento alinhar, de uma maneira bem geral, desde como esse cuidador deve se portar na casa, não só o aspecto técnico, pra que diminuam as insatisfações e a gente não tenha tanta rotatividade dentro da casa. (G.IV.5.11)

A minha relação é ótima com as sócias, com os cuidadores que estão dentro das casas, à gente tem uma boa sintonia, e eu acho que por enquanto eu estou indo bem, vamos ver pra frente. (G.V.11.51) 


\section{Gerenciar a escala da equipe de cuidadores}

a escala por exemplo, estar de olho na escala e tentar suprir as necessidades do cuidador, desse profissional, faz com que ele tenha, que ele esteja feliz e satisfeito de estar trabalhando na empresa. E isso automaticamente impacta no cuidado do idoso. (G.II.4.12)

Tentar controlar para que não tenha muitos furos de escala, e a gente possa manter a qualidade nisso. (G.IV.5.10)

\section{Identificar e atender as necessidades do paciente e sua família}

o gerontólogo vai identificar as maiores demandas, vai estar atento para essas demandas, estar atento ao idoso, porque o gerontólogo é um profissional importantíssimo para acompanhar esse idoso. (G.II.5 .16)

ele conhecendo esse idoso ele vai conseguir entender e identificar quando tiver alguma coisa errada com esse idoso, identificar o que esse idoso precisa, o que ele quer, então a partir disso você vai conseguir orientar o cuidador, né? (G.II.5.17)

Fazer seleção de cuidadores, auxiliares de enfermagem de acordo com o perfil do paciente, mãe também fazer contato com a família para monitorar qual a satisfação da família em relação ao nosso atendimento. (G.IV.4.8)

...eu tenho o contato com a família, levando o cuidador do perfil esperado. (G.V.6.25)

e alinhando as expectativas do que este cuidador pode realizar, o que são atribuições esperadas por este cuidador dentro da casa. (G.V.6.26)

\section{Aprender com as situações e ter resolutividade}

que você tem que ter muita inteligência emocional pra lidar, muita, porque são varias situações desafiadoras, que você perde o chão, mas depois você respira fundo, e pensa "como é que a gente vai resolver?" (G.I.13.31)

é uma responsabilidade grande, não é uma responsabilidade compartilhada como em outros equipamentos que prestam cuidado ao idoso(G.II.2.49)

eu acho que é desafiador, porque como eu falei anteriormente, você tem que ser ágil, você tem que resolutiva, e isso você só desenvolve na prática, e acho que em nenhum outro lugar eu teria desenvolvido essas habilidades se não fosse na assistência domiciliar.(G.III.12.11)

Minha atuação como gerontóloga no cuidado domiciliar, ela é de constate aprendizado porque cada caso é um caso e você vai entendendo que a heterogeneidade é muito forte, como o idoso viveu a vida dele inteira, e agora como ele está vivendo, se aquilo está sendo respeitado ou 
não, são exemplos que você consegue aprender a como lidar e aquilo vai servir para outros cuidados que você vai prestar. (G.II.11.35)

A minha atuação hoje como gerontóloga é de constante aprendizado e de empatia, de se colocar no lugar do outro, não só do próprio paciente de como ele gosta e quer ser cuidado, mas também da família que está numa situação difícil. (G.II.11.36)

eu acredito que eu estou desempenhando esse papel dentro do possível e sempre aprendendo a como fazer isso, pois cada caso é um caso, então não tem como saber de tudo, mas como a gente consegue observar muito, a gente consegue entender como as coisas funcionam $e$ consegue atingir uma excelência naquilo que a gente faz que é fazer a gestão desse cuidado. (G.II.11.38)

\section{Ter mais flexibilidade e autonomia no trabalho}

você não está dentro de uma instituição então você tem autonomia pra decidir aquilo que você quer(G.II.12.39)

você também consegue ter uma flexibilidade maior de horário, não é uma coisa que você tem que bater ponto porque é uma coisa muito flexível, dinâmica o tempo todo, então tem hora que você vai pra um lugar ou pra outro, tem varias casas, vários idosos, então existe essa flexibilidade de tempo né? (G.II.12.40)

nessa empresa, eu tenho autonomia de resolver as coisas, de decidir as coisas, a gente não depende de um médico ou de um enfermeiro para decidir as coisas, a gente chega e fala "olha eu resolvi por esse cuidado e pronto, a gente tem que seguir nessa linha e pronto.". (G.III.12.12)

\section{Ter contato próximo com o idoso}

ter um contato mais próximo, você criar um vinculo maior com aquele idoso, então você vai acompanhar aquele caso, você vai estar ali o tempo todo, você vai do começo até o fim do cuidado. (G.II.12.41)

A relação que é gratificante demais, com o idoso principalmente, é o que eu considero uma das principais vantagens na atuação do cuidado domiciliar. (G.III.12.10) contato próximo com o paciente, que em alguns serviços a gente não tem esse contato tão direto (G.V.12.52)

\section{Colocar os conhecimentos teóricos em prática}


a vivência de trabalhar nos cuidados no domicílio na verdade é uma oportunidade de colocar tudo o que eu aprendi na teoria na prática (G.V.2.11)

é uma área que eu estudo, que eu gosto e me interesso, é uma área que eu já pesquisei muito, e agora eu tenho a oportunidade de trabalhar como gerontóloga naquilo que eu via nos artigos e nos trabalhos que eu fiz.(G.V.2.12)

a gente vai tendo que desenvolver e buscar lá o que a gente aprendeu. (G.V.11.47)

a gente realmente consegue atuar no que a gente sabe, no que a gente aprendeu na graduação.(G.V.12.55)

\section{Mediar o cuidado}

"eu vejo o gerontólogo como um mediador, então um mediador entre os cuidadores, um mediador entre as pessoas" (G.V.1.1)

"eu sempre médio as demandas da família, as demandas que os cuidadores trazem, a demanda do próprio paciente" (G.V.1.2)

Quando eu vejo algum erro eu tento mediar de uma forma que elas não se sintam pressionadas ou que elas não se sintam corrigidas, isso nunca acontece na frente de alguém, eu sempre abordo sozinha com cada uma...Eu tento mediar, me cercar do que aconteceu, ouvir a versão delas, e ai depois dar uns puxões de orelha. (G.V.8.31)

Empatia, tentar entender o outro e de mediação, sempre mediando conflitos o tempo inteiro. $O$ gerontólogo faz muito esse papel no cuidado domiciliar, de gerir esses conflitos entre a família o idoso e o cuidador. (G.II.11.37)

\section{Supervisionar o cuidado}

Então o gerontólogo é a pessoa que olha para todo aquele ambiente, que supervisiona. (G.V.1.7)

...eu faço a supervisão de um deles semanalmente e de dois deles quinzenalmente. (G.V.4.15) No cuidado domiciliar que eu exerço hoje, eu sou principalmente uma supervisora dos cuidados realizados pelos cuidadores. (G.V.5.20)

Então é mais uma supervisão do que eles (cuidadores) realizam, do que a família espera como plano de cuidados, o que eles esperam que este cuidador faça. (G.V.5.23)

\section{Incentivar o respeito, a autonomia e independência do idoso}


E sempre buscando que eles incentivem este idoso a obter uma maior autonomia, uma maior independência, manter estas atividades preservadas né? Nunca tirar isso deles, sempre incentivá-los.(G.V.5.24)

eu evito falar sobre o idoso como se ele não estivesse ali, eu gosto que ele participe deste processo. (G.V.7.29)

a questão de você preservar o valor do indivíduo idoso, que ele vai ter aí um pouco da vontade dele respeitada. (G.I.12.28)

\section{Zelar pela segurança do idoso}

A gente teve até um recente caso que a gente suspeitou de agressão por parte da família, e a gente foi pra cima, à gente conversou com o filho a gente conversou com o cuidador, a gente começou a cercar esta família, porque se realmente se a gente souber que algo aconteceu contra este idoso eles estão cientes que a gente pode romper contrato, que a gente pode denunciar, e isso a gente fala já no começo, na primeira avaliação a gente já coloca para a família que se algo acontecer que seja fora do que está previsto no estatuto do idoso, ou que tenha algum tipo de agressão moral ou física a este paciente, que a gente vai se posicionar.(G.V.9.34)

As cuidadoras são orientadas o tempo inteiro se elas verem algum tipo de marca, se elas verem que o estado clínico do paciente, se elas verem que algo não está normal, a gente todos os dias a gente tem um relato de plantão pelo WhatsApp, e elas nos falam o que está acontecendo as preocupações delas em relação a estes pacientes. (G.V.9.39/40)

\section{Incentivar a família para um melhor cuidado}

eu vejo principalmente pelo que eu falei desta mediação que o gerontólogo faz, a família eu vejo que ela tem mais cuidado da forma que ela lida com o idoso (G.V.9.35)

Então eu sinto que a família fica mais cuidadosa, porque ela sabe que não é alguém que esta ali só para fazer o que ela quer. (G.V.9.36)

\section{DIFICULDADES ENFRENTADAS PELO GERONTÓLOGO}

\section{Desconfiança dos idosos}

e tem a desconfiança natural, porque todos os idosos olham pra gente meio assim "está ela é a pessoa, que é a fiscal", umas até falam assim "precisa pagar um caminhão de dinheiro pra ela."(G.I.7.22) 


\section{Ficar a disposição integral}

você fica a disposição o tempo todo. É uma desvantagem, mas ela faz parte do pacote, só que você consegue resolver, tá? (G.I.13.30)

então é uma desvantagem você ter que estar disponível a qualquer momento para aquela família que está recebendo o cuidado né? (G.II.13.43)

\section{Relacionamento com os profissionais da equipe multiprofissional}

A maior dificuldade do gerontólogo de exercer sua profissão seja dentro do domicílio ou não, é a relação com os outros profissionais envolvidos.(G.II.10.28)

Então as vezes os outros profissionais não conseguem compreender ou não deixam que o gerontólogo faça o seu papel. (G.II.10.29)

Profissionais que não são da área e querem prestar o cuidado, prestar a gestão do cuidado mesmo não tendo se especializado na área é nossa grande dificuldade, pro gerontólogo atuar. (G.II.10.30)

Uma das maiores dificuldades do gerontólogo é essa, a relação interprofissional. (G.II.10.31) a falta de equipe multiprofissional junto com os gerontólogos. (G.III.13.13)

\section{Desconhecimento sobre a profissão de gerontólogo}

a outra é o profissional entender o que o gerontólogo faz, e a importância que tem o gerontólogo no caso, e entender que não tem outro profissional que faça essa gestão com esse tipo de enfoque e atenção, com o olhar diferenciado (G.II.10.32)

a dificuldade, no geral é essa, das pessoas entenderem o que o gerontólogo faz, e os cuidadores entenderem o papel. (G.II.10.34)

porque o gerontólogo ainda é uma profissão que não é toda a família que sabe o que ele faz. (G.IV.10.14)

eu acho que ainda existe, no primeiro momento, eu acho que a família fica um pouco receosa, eu acho que essa é a principal dificuldade, a falta de informação sobre o profissional gerontólogo. (G.IV.10.15)

\section{Rotatividade de cuidadores de idosos}

Outra desvantagem é o estresse que causa a rotatividade de cuidador, então, é muito difícil manter um cuidador num mesmo local, então é uma desvantagem de insegurança e estresse 
muito grande de você ter uma rotatividade de cuidador ali, sendo que você já conhece o idoso. (G.II.13.44)

\section{Atendimento restrito ao domicílio}

o cuidado estar restrito ao domicilio, muitas vezes o paciente precisa de um convívio social, ele precisa outras intervenções, ele precisa frequentar outras lugares, mas como ele está tendo o cuidado em casa é muito difícil a família ter condições financeiras de manter o cuidador em casa e mantê-lo em outros lugares que possam trazer conforto, que possam trazer é estimulação cognitiva, social... (G.II.13.45)

Ficar restrito ao domicilio é uma desvantagem, e isso limita um pouco o papel do gerontólogo pra melhorar ainda mais a qualidade de vida desse paciente. (G.II.13.46)

\section{Não ter rotina de horários}

Eu acredito que foi mais a questão da rotina, porque não tem rotina, e eu sou uma pessoa bem rotineira, né? Então eu acho que foi um desafio pra mim, uma dificuldade e também um desafio. (G.III.3.4)

\section{Ser resolutivo e rápido nas decisões}

E acho que a questão também de lidar com problemas em curto espaço de tempo, eu tenho que ser resolutiva, com os problemas que acontecem no dia a dia, nos plantões que eu dou de final de semana, e ser resolutiva, então essa foi uma grande dificuldade pra mim também, né? (G.III.3.5)

\section{Pouco retorno financeiro}

o retorno financeiro, não sei se é geral nos home cares aqui no Brasil, mas, eu sinto que é muito baixa, pelo tanto de carga que a gente tem, não só de carga horária e trabalho, mas carga psicológica e emocional que a gente tem, eu senti muita desvantagem nesse sentido. (G.III.13.14)

Depende muito do tamanho da empresa que você trabalha, pode ser que o salário não chegue a sua expectativa. (G.IV.13.20)

\section{Dificuldade de delimitar as funções do gerontólogo}

Fora a dificuldade do gerontólogo em ter seu lugar ali dentro dos cuidados do idoso. (G.II.10.33) 
como o gerontólogo não tem muito definido a atuação, você cada vez acaba ganhando mais uma. (G.IV.10.21)

essa falta de um fechamento real de quais funções, você vai sempre englobando mais uma e a sua demanda vai crescendo, então nesse sentido, eu acredito que acaba sendo uma desvantagem porque a gente não tem muito limitado o que fazer. (G.IV.10.22)

Principalmente questões éticas, sempre a gente tem que colocar a mão na consciência "o que esperado de um gerontólogo? o que a gente viu nas disciplinas? Na nossa formação o que é cabivel dizer aqui, e o que não é cabivel?" "será que eu não estou extrapolando e passando para outra área?" Então sempre estar atenta aos limites que eu tenho como gerontóloga, para não entrar em outras áreas(G.V.48.11)

a geronto me ajudou muito nisso, o que me falta um pouco é o olhar mais técnico, eu tenho bastante duvidas técnicas que ai eu preciso de uma enfermeira para complementar. (G.IV.1.2)

\section{Ser visto como auditor}

algumas famílias até se sentem um pouco intimidadas com isso, porque se tiver alguma coisa errada o gerontólogo também vê, em relação ao que eles fazem com o paciente. (G.V.1.8)

\section{Falta de autonomia}

no meи caso, eu sinto que muitas vezes eu não tenho autonomia de fazer o que eu gostaria de fazer.(G.V.10.43)

Então às vezes eu me sinto um pouco podada dentro deste atendimento. (G.V.10.44) eu não tenho esta autonomia dentro da empresa. (G.V.10.46)

No meu caso, eu não posso atuar de uma forma ampla como gerontóloga. (G.V.14.57)

\section{Falta de oportunidade para traçar planos e metas gerontológicas}

Às vezes eu fico muito mais voltada para uma supervisão realmente, do que um atendimento gerontológico, um plano de atenção que eu posso ter metas, que eu posso ter um plano de ações com aquele paciente, com aquela família, intervir família e paciente junto.(G.V.45.10)

\section{Dificuldade de se posicionar como gerontóloga}

mas também me posicionar como gerontóloga, como uma gestora daquele caso, porque acho que eu ainda não sou vista dessa forma, nos casos, mais como uma supervisora mesmo.(G.V.49.11) 


\section{Limitações e resistências impostas pela família}

que eu acho que a gente tem algumas limitações que são advindas da família. A família é o ponto mais forte nesta relação, se ela aceitar o seu cuidado, sua orientação e suas dicas bem, se sentir desconfortável com aquilo que você contribui simplesmente você pode sair daquele caso, mesmo sabendo que aquele idoso talvez não esteja melhor forma (G.V.56.13) 